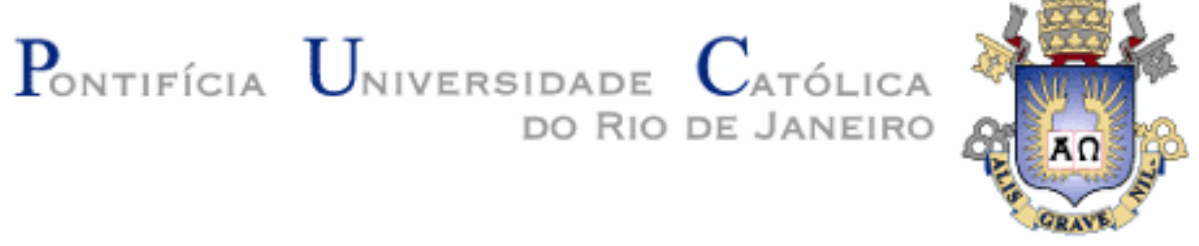

D'avila Maria Gomes Mendes

\title{
Avaliação da aceitabilidade de um sistema de apoio à logística humanitária
}

Dissertação de Mestrado

Dissertação apresentada como requisito parcial para obtenção do grau de Mestre pelo Programa de PósGraduação em Engenharia de Produção do Departamento de Engenharia Industrial da PUC-Rio.

Orientador: Prof. José Eugênio Leal Coorientador: Prof. Tharcisio Cotta Fontainha

Rio de Janeiro

Outubro de 2019 


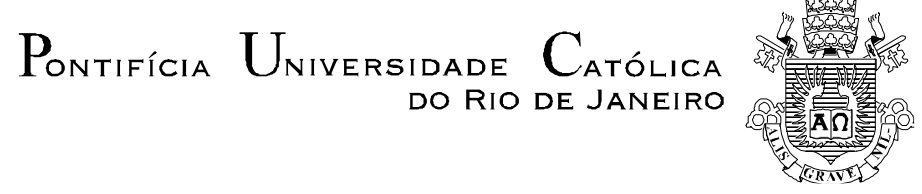

\title{
D’avila Maria Gomes Mendes
}

\section{Avaliação da aceitabilidade de um sistema de apoio à logística humanitária}

Dissertação apresentada como requisito parcial para obtenção do grau de Mestre pelo Programa de Pós-Graduação em Engenharia de Produção da PUCRio. Aprovada pela Comissão Examinadora abaixo.

\author{
Prof. José Eugênio Leal \\ Orientador \\ Departamento de Engenharia Industrial - PUC-Rio
}

Prof. Tharcisio Cotta Fontainha

Co-orientador

Universidade Federal do Rio de Janeiro - UFRJ

Profa. Renata Albergaria de Mello Bandeira Instituto Militar de Engenharia - IME

Prof. Orivalde Soares da Silva Júnior Instituto Militar de Engenharia - IME

Rio de Janeiro, 18 de outubro de 2019 
Todos os direitos reservados. É proibida a reprodução total ou parcial do trabalho sem autorização da universidade, do autor e do orientador.

D'avila Maria Gomes Mendes

Engenheira de Produção pela PUC e Mestranda em Engenharia de Produção pela mesma instituição. Sua produção acadêmica durante o mestrado resultou em 3 artigos publicados em anais de eventos, sendo um deles internacional. Atua na gerência de monitoramento e avaliação de Ensino Integral da Secretaria de Educação do Estado de Goiás.

Ficha catalográfica

Mendes, D'avila Maria Gomes

Avaliação da aceitabilidade de um sistema de apoio à logística humanitária / D'avila Maria Gomes Mendes ; orientador: José Eugênio Leal ; co-orientador: Tharcisio Cotta Fontainha. - 2019.

122 f. : il. color. ; $30 \mathrm{~cm}$

Dissertação (mestrado)-Pontifícia Universidade Católica do Rio de Janeiro, Departamento de Engenharia Industrial, 2019.

Inclui bibliografia

1. Engenharia Industrial - Teses. 2. Doações. 3. Logística humanitária. 4. Aceitabilidade de software. 5. Usabilidade. 6. Comportamento doador. I. Leal, José Eugênio. II. Fontainha, Tharcisio Cotta. III. Pontifícia Universidade Católica do Rio de Janeiro. Departamento de Engenharia Industrial. IV. Título. 


\section{Agradecimentos}

Agradeço primeiramente a Deus que jamais me abandonou e que sempre foi um refúgio nos momentos de desesperança. Aos meus amados pais, que nunca mediram esforços para garantir que minha trajetória fosse o menos sacrificante possível, e que sempre me incentivaram na busca dos meus sonhos, mesmo quando não entendia que possuía o direito de sonhar. Vocês são meus maiores exemplos de integridade e fé.

A toda minha família e aos meus amigos, tanto aqueles que já faziam parte da minha vida antes de iniciar o mestrado, quanto aos que adentraram nela ao longo desse processo (Breno, Júlia, Jéssica, Ludmylla, Vinicius, Kamila, Leonardo, Soraida e todos os demais). Sem vocês esse processo seria muito mais penoso e muito menos divertido.

A todos os educadores que me inspiraram ao longo da minha trajetória acadêmica e acreditaram no meu potencial. Agradeço especialmente ao meu orientador, José Eugênio, que me abriu as portas da pesquisa científica desde a graduação e sempre contribuiu enormemente no meu aprendizado. Ao meu coorientador e amigo, Tharcísio Fontainha, que contribuiu enormemente para esta pesquisa e me deu muita segurança durante todo o processo. A toda a equipe de professores do Departamento do DEI, por todo conhecimento compartilhado e a Cláudia e toda equipe administrativa pelo suporte que nunca faltou.

Agradeço à banca examinadora por contribuir para a validação e aprimoramento desta pesquisa.

Àquelas que vieram antes de mim e que lutaram para que hoje pudesse chegar até aqui, minha eterna gratidão.

O presente trabalho foi realizado com 0 apoio da Coordenação de Aperfeiçoamento de Pessoal de nível Superior - Brasil (CAPES) - Código de Financiamento 001. 


\section{Resumo}

Mendes, D'avila Maria Gomes; Leal, José Eugênio (Orientador); Fontainha, Tharcisio Cotta (Co-orientador). Avaliação da aceitabilidade de um sistema de apoio à logística humanitária. Rio de Janeiro, 2019. 122p. Dissertação de Mestrado - Departamento de Engenharia Industrial, Pontifícia Universidade Católica do Rio de Janeiro.

Este trabalho visa avaliar um sistema de doações via internet para operações humanitárias e assistência, o SmartDonation, cujo principal objetivo é gerenciar os recursos necessários para suprir as necessidades dos beneficiários. Através da interface de uma loja virtual, permite a efetuação de doações para diversas campanhas, através de doações monetárias. Desta forma, o sistema propõe uma melhor gestão nas operações de assistência humanitária através da compra em maior escala, trazendo maior economia nos processos operacionais. O objetivo do estudo é analisar a aceitabilidade do sistema, além de compará-lo com ferramentas já existentes no campo de gestões humanitárias. Para isto, utilizou-se como métodos de pesquisa a revisão sistemática da literatura (RSL), a fim de identificar as principais ferramentas utilizadas em gerenciamento de doações e comparar suas funcionalidades; o estudo de caso, a fim de investigar a aceitabilidade por parte das instituições; e a pesquisa survey, para investigar a aceitabilidade do sistema por parte de potenciais doadores. Como resultado da RSL foram identificadas 17 ferramentas utilizadas na otimização de doações. Das 19 funcionalidades avaliadas, o sistema atende a 12. Na análise do estudo de caso foi constatada a necessidade de resolução de problemas encontrados pelas instituições, mas que não comprometeram sua utilidade percebida. $\mathrm{Na}$ análise da survey identificou-se a potencialidade do sistema em mudar positivamente o comportamento de usuários avessos a doação financeira; e maior inclinação à doação em desastres de início súbito e causas naturais. Os três métodos são complementares e atestam a aceitabilidade do sistema pelos stakeholders envolvidos.

\section{Palavras-chave}

Doações; logística humanitária; aceitabilidade de software; usabilidade; comportamento doador; experiência do usuário 


\section{Abstract}

Mendes, D’avila Maria Gomes; Leal, José Eugênio (Advisor); Fontainha, Tharcisio Cotta (Coadvisor). Acceptability evaluation of a support system for humanitarian logistics. Rio de Janeiro, 2019. 122p. Dissertação de Mestrado - Departamento de Engenharia Industrial, Pontifícia Universidade Católica do Rio de Janeiro.

This work aims to analyze a system of internet donations for humanitarian operations and social assistance, the SmartDonation, whose main objective is to manage the resources needed to meet beneficiaries's needs. An online store interface allows monetary donations to various campaigns. In this way, the system proposes a better management in humanitarian assistance operations through the large scale purchasing, bringing greater economy in the operational processes. The study objective is to analyze the acceptability of the system by potential donors and institutions, as well as to compare it with existing tools in the field of humanitarian management. For this, the Systematic Literature Review (SLR) was used as research method, in order to identify the main tools used in donation management and to compare their functionalities; the case study was used in order to investigate the acceptability of institutions; and a survey to investigate the acceptability of the system by potential donors. As a result of the RSL, 17 tools were used to optimize donations, and of the 19 functionalities evaluated, the system caters to 12 of them. In the case study analysis, it was verified the need to solve problems encountered by users in the usability test, but did not compromise their acceptability and perceived utility. The analysis of the survey identified the potential of the system to positively change the behavior of users averse to financial donations, and a greater inclination to donate in sudden-onset disasters and natural hazards. The three methods are complementary and attest to the acceptability of the system by the stakeholders involved.

\section{Keywords}

Donations; humanitarian logistics; software acceptability; usability; donor behavior; user experience 


\section{Sumário}

1 INTRODUÇÃO .........................................................................13

1.1. ConteXtualizaÇÃo E PROBLEMA DE PESQUiSA ................................ 13

1.2. OBJETO DE PESQUISA...................................................... 16

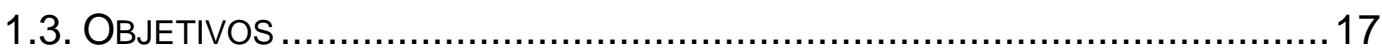

1.4. JUSTIFICATIVA DA PESQUISA ................................................. 18

1.5. ESTRUTURA DO TRABALHO.......................................................... 19

2 REFERENCIAL TEÓRICO...........................................................20

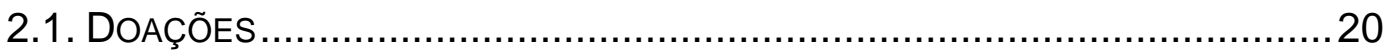

2.1.1. Doações não solicitadas e convergência de materiais ..................20

2.1.2. Doações monetárias $x$ doações materiais...................................21

2.1.3. Avaliação sob a perspectiva dos doadores .................................23

2.2. PROCESSO DE COMPRAS E AQUISIÇÃO ...........................................25

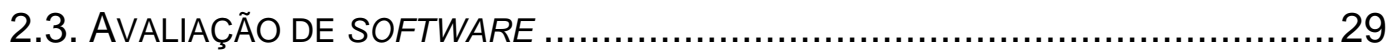

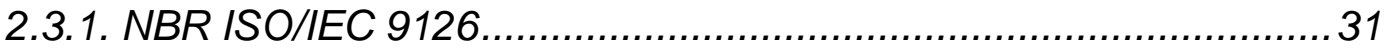

2.3.2. Atributos específicos - Usabilidade........................................ 32

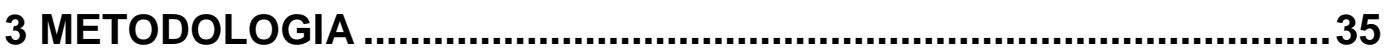

3.1. REVISÃo SISTEMÁtICA dA LITERATURA (RSL) .................................... 35

3.2. ESTUDO DE CASO.................................................................. 37

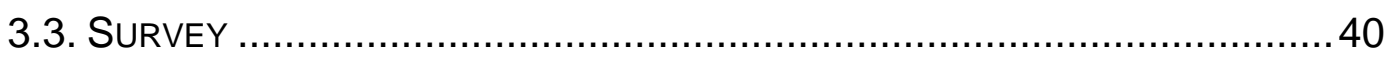

4 ANÁLISE DAS FUNCIONALIDADES DO SMARTDONATION ..........43

5 ESTUDO DE CASO ...................................................................52

5.1. SíNTESE DO PROCESSO DE DOAÇÕES NAS INSTITUIÇÕES .......................54

5.2. SÍNTESE DO PROCESSO DE COMPRAS NAS INSTITUIÇÕES ........................58

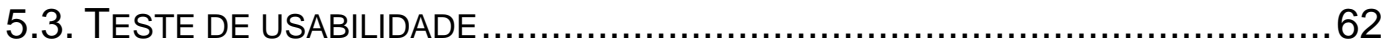

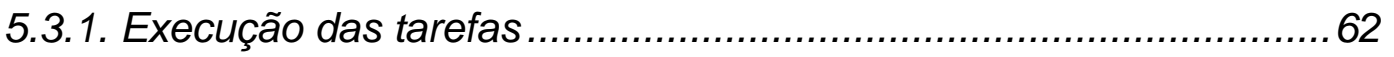

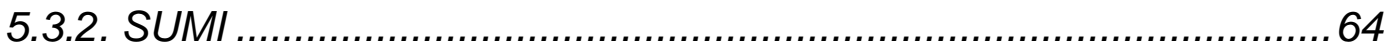

5.4. ANÁLISE FRENTE ÀS INSTITUIÇÕES DE AJUDA HUMANITÁRIA ....................69

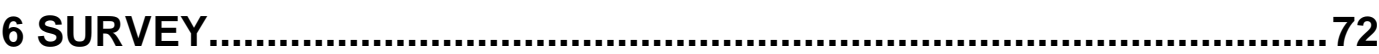


6.1. RESULTADOS DA ESTATÍSTICA DESCRITIVA .......................................

6.2. ANÁLISE DO SMARDONATION FRENTE À PERCEPÇÃO DE DOADORES ..........81

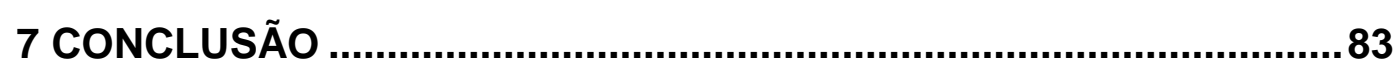

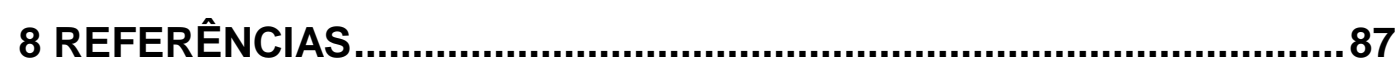

APÊNDICE 1 - PROTOCOLO DE PESQUISA …...................................96

APÊNDICE 2 - INSTRUMENTOS DA SURVEY ................................102

APÊNDICE 3 - FUNCIONALIDADES E CARACTERÍSTICAS..............110

APÊNDICE 4 - MATRIZ GUT E OCORRÊNCIAS CRÍTICAS................113

APÊNDICE 5 - FATORES QUE INFLUENCIAM A DOAÇÃO ..............115

ANEXO 1 - INSTRUMENTO DE PESQUISA 4 - SUMI.........................120 


\section{Lista de figuras}

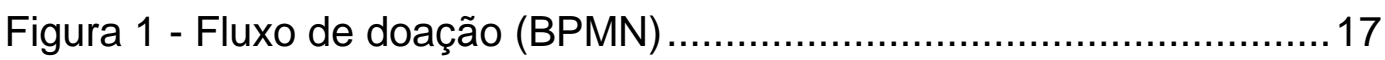

Figura 2 - Atributos de aceitabilidade de sistemas ..................................30

Figura 3 - Etapas do estudo de caso....................................................... 38

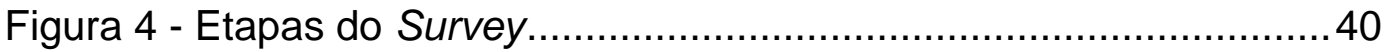

Figura 5 - Médias por escala SUMI com 95\% de intervalo de confiança . 67

Figura 6 - Etapas de coleta de dados nas instituições ............................97

Figura 7 - Fluxo do questionário do doador..........................................102 


\section{Lista de tabelas}

Tabela 1 - Funcionalidades e características das ferramentas ...............46

Tabela 2 - Funcionalidades e características adicionais ......................49

Tabela 3 - Resumo do desempenho dos usuários ...............................64

Tabela 4 - Pontuações das escalas avaliadas por instituição ..................65

Tabela 5 - Resumo estatístico do teste de usabilidade (SUMI) ...............65

Tabela 6 - Valores preferenciais de doações ao ano (\%) .......................115

Tabela 7 - Fatores motivacionais no ato de doar ..............................116 


\section{Lista de quadros}

Quadro 1 - Tarefas relacionadas ao processo de aquisição em LH .........28

Quadro 2 - Comparação entre os resultados da RSL e sua atualização..37

Quadro 3 - Fatores identificados na Survey ...........................................41

Quadro 4 - Resumo das ferramentas encontradas .................................4 44

Quadro 5 - Unidades de análise do estudo de caso.................................53

Quadro 6 - Síntese das questões referentes a doações ..........................56

Quadro 7 - Síntese das etapas do processo de compras por instituição .58

Quadro 8 - Síntese sobre o processo de compras das instituições...........60

Quadro 9 - Pontos fracos e fortes estatisticamente significantes .............67

Quadro 10 - Comparativo antes e após a apresentação do sistema.........76

Quadro 11 - Taxa de migração positiva por tipo de desastre ....................80

Quadro 12 - Critérios de seleção das instituições ..................................96

Quadro 13 - Instrumento de pesquisa 1 .............................................. 98

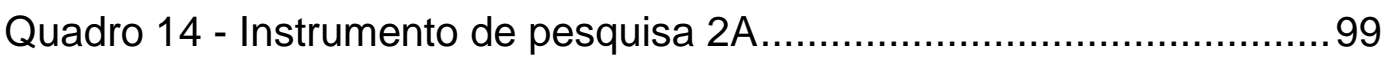

Quadro 15 - Instrumento de pesquisa 5C …………........................... 105

Quadro 16 - Funcionalidades e características dos sistemas ................110

Quadro 17 - Matriz GUT e ocorrências do teste de usabilidade ..............113

Quadro 18 - Importância de fatores para o doador ..............................117

Quadro 19 - Formas de pagamento preferenciais ................................118

Quadro 20 - Formas preferenciais para acompanhamento .....................118 


\section{Lista de gráficos}

Gráfico 1 - Critérios de qualidade e usabilidade dos questionários ...........34

Gráfico 2 - Propensão à doação de suprimentos .................................73

Gráfico 3- Propensão à doação de vestuário ......................................74

Gráfico 4- Propensão à doação financeira .........................................74

Gráfico 5 - Classificação antes e após a apresentação do sistema .........77

Gráfico 6 - Respondentes (início súbito e causa natural) ......................78

Gráfico 7 - Respondentes (início lento e causa natural)........................78

Gráfico 8 - Respondentes (início súbito e causa humana) .....................79

Gráfico 9 - Respondentes (início lento e causa humana) ......................80 


\section{1 \\ Introdução}

Nesta seção são abordados assuntos pertinentes à apresentação do trabalho, incluindo a contextualização e problemática do tema, o objeto de pesquisa, o objetivo geral e os específicos, motivação, justificativa da escolha do tema e a estrutura do trabalho.

\subsection{Contextualização e problema de pesquisa}

Desastres podem ser definidos como sérias perturbações do funcionamento de uma comunidade ou sociedade que envolva perdas e impactos humanos, materiais, econômicos ou ambientais generalizados, que excede a capacidade da comunidade ou sociedade afetada de lidar com seus próprios recursos. São frequentemente descritos como resultado da combinação de exposição ao perigo; as condições de vulnerabilidade presentes; e capacidade ou medidas insuficientes para reduzir ou enfrentar as potenciais consequências negativas. Os impactos de desastres podem incluir a perda de vidas, ferimentos, doenças e outros efeitos negativos no bem-estar físico, mental e social, juntamente com danos à propriedade, destruição de bens, perda de serviços, perturbação social e econômica e degradação ambiental (UNISDR, 2017).

Os desastres podem ser classificados quanto a sua origem como derivados de causas naturais ou causados pelo homem e quanto a sua a evolução de início súbito ou de início lento (Van Wassenhove, 2006). Um estudo recente do CRED (Centre for Research on the Epidemiology of Disasters) evidencia que a redução do número total de desastres naturais nos últimos anos não significa necessariamente uma diminuição nos danos gerados. O número de pessoas afetadas por desastres em 2018 foi de aproximadamente 68 milhões de pessoas (CRED, 2019), enquanto o registrado em 2017 foi de 96 milhões (Below e Wallemacq, 2018), contudo essa diminuição não representou redução no número de mortes, que aumentou quase $20 \%$, mesmo com a redução do número de desastres naturais registrados (335 em 2017 para 315 em 2018). Além disso, o número de desastres causados pelo homem, como crise de refugiados e guerras civis vem crescendo na útlima década, algumas fontes de notícias consideram "a 
maior crise humanitária desde a Segunda Guerra Mundial" (BBC, 2017; The Washington Post, 2017), evidenciando a latente necessidade de estudos no campo de desastres.

Considerando esse contexto de desastres, tem-se a Logística Humanitária (LH) como área de atuação que compreende processos de planejamento, implementação e controle do fluxo e armazenagem de recursos, assim como informações relacionadas a desastres e que visa minimizar o impacto da ocorrência dos mesmos (Thomas e Kopczak, 2005). O gerenciamento dessa cadeia de suprimentos é um dos maiores desafios para operações humanitárias devido a quantidade de agentes envolvidos, seus diferentes objetivos, a falta de coordenação e integração entre eles, além da falta de infraestrutura presente nos locais atingidos (Leiras et al., 2014; Akhtar, Marr e Garnevska, 2012; Kovács e Spens, 2007). Como área de pesquisa, observa-se um crescimento considerável nas pesquisas acadêmicas relacionadas a temática, o que evidencia a importância e sua relevância atual. Mesmo com tal crescimento, em sua revisão da literatura Behl e Dutta (2018) apontam possíveis direções para pesquisas futuras que passam por lacunas em temas pouco abordados em revisões, métodos de pesquisa usando grupos focais e étnicos, big data, assim como a utilização estudos empíricos longitudinais.

No que tange o gerenciamento da cadeia de suprimentos em operações humanitárias, Smilowitz e Dolinskaya (2011) enfatizam o grande desafio em estabilizar o fluxo de doações de diferentes fontes (nacionais e internacionais) com o mínimo desperdício de recursos. Já Fritz e Mathewson (1957) denominam o fluxo de suprimentos, doações gerais (solicitadas ou não solicitadas) e equipamentos que chegam ao local do desastre como convergência de materiais. Holguín-Veras et al. (2012) destacam este fenômeno com um dos mais específicos, negligenciados e mal compreendidos do desastre. Grande quantidade de suprimentos e equipamentos são enviados para a área do desastre por milhares ou dezenas de milhares de doadores (por exemplo, indivíduos, grupos religiosos, organizações sem fins lucrativos, empresas, governos). O cerne do problema é que os materiais e suprimentos que convergem no local do desastre incluem uma grande proporção de produtos inadequados ou inúteis que causam estragos na resposta a desastres. Um exemplo que demonstra o quão problemático pode ser a convergência de materiais é relatado por Chomilier et al. (2003), na resposta ao terremoto de 1993 em Bangladesh, onde 95\% das doações recebidas foi considerada indesejada. E apesar dos constantes esforços para 
evolução logísticas, evidências de casos semelhantes são relatados em outros estudos (Holguin-Veras et al., 2012).

No Brasil, alguns estudiosos evidenciam em suas pesquisas esse fenômeno da convergência de materiais. Carneiro et al. (2014) analisam a resposta ao desastre de Cubatão ocorrido em fevereiro de 2013 em São Paulo, bem como sua fase de reconstrução. Varella e Gonçalves (2017) analisam a gestão de doações na cidade de Ponte Alta do Norte, Santa Catarina, atingido por microexplosões em maio de 2016. $\mathrm{Na}$ análise, os autores identificam diversos problemas como falta de controle de estoques, desperdícios, excesso de donativos, contaminação e doações incompatíveis e inadequadas. Já Cruz, Nascimento e Bueno (2017) analisam a coleta e distribuição de donativos no desastre de Mariana - MG, conhecido como maior desastre ambiental do Brasil em novembro de 2015, por meio de entrevista com o criador do Conselho Logístico Humanitário Nacional $(\mathrm{CLNH})$, que salienta as dificuldades enfrentadas na gestão de doações e atendimento às vítimas. Por isso Behl e Dutta (2018) afirmam ainda ser necessário explorar áreas inexploradas, indicando especificamente o papel dos doadores individuais e organizacionais e seu impacto nas operações de reposta a desastres, além da inclusão de elementos de comportamento como transparência, confiança, tipo de doações etc. e fatores baseados no desempenho, como tempo e volume de ajuda.

Observa-se assim que os desafios logísticos são enormes: uma vasta quantidade de itens, um fluxo extremamente heterogêneo, chegando a um curto espaço de tempo a uma área com espaço, recursos e pessoal limitados para processá-los e distribuí-los aos destinatários pretendidos. Dado que o processo de doação é extremamente impactante na geração de convergência material aprimorá-lo pode reduzir significantemente este gargalo na cadeia de suprimentos. Segundo Özpolat et al. (2015), doações monetárias permitem que as organizações de ajuda humanitária comprem suprimentos que correspondam diretamente às necessidades em mudança no campo, ao mesmo tempo em que permitem que os logísticos planejem com mais eficiência o armazenamento, o transporte e a entrega de suprimentos. Este fato é corroborado pelo estudo feito por Gelan (2006), no qual demonstra a eficiência relativa superior entre doações monetárias e materiais, através de uma estrutura de modelagem econômica. No entanto, um dos entraves à doação em dinheiro ainda é o comportamento conservador do doador, ligado ao receio quanto ao destino final das doações e consequente exigência dos doadores na transparência e eficiência na aplicação dos recursos pelas organizações. Por esta razão o uso de sistemas informatizados 
capazes de trazer não só ganhos logísticos, como também transparência para a alocação de recursos pode contribuir uma melhor resposta em termos de eficiência, eficácia e equidade para a resposta a desastres.

\subsection{Objeto de pesquisa}

Considerando a problemática sobre o gerenciamento de doações na cadeia de suprimentos de operações humanitárias, a academia juntamente com os profissionais da área busca o desenvolvimento de melhorias nos processos de gerenciamento de doações. Uma das soluções propostas, e objeto da presente pesquisa, é um sistema de doações proposto por Salvino e Leal (2012), que permite que os doadores visualizem as quantidades de suprimentos necessárias para cada campanha em uma loja virtual e efetuem a compra dos itens a serem fornecidos para os beneficiários. As quantidades são definidas pelas organizações através da análise da demanda que pode ser feita ou não através do sistema. Com as quantidades definidas, é possível solicitar cotações para fornecedores cadastrados no sistema e calcular o valor unitário a ser repassado para o usuário doador. Desta forma, espera-se ganhos em termos econômicos e em assertividade, visto que as operações de compra e transporte passam a ser centralizadas e unificadas, evitando problemas com data de expiração, estado de conservação e alocação de recursos financeiros e humanos em tarefas não prioritárias. Por essa razão, o sistema recebe o nome SmartDonation.

O sistema pode ser descrito como uma ferramenta de apoio para aquisição de bens, controle de estoques e disponibilização, para organizações de ajuda humanitária. O sistema possui funcionalidades não só para agências humanitárias (administradoras), como também para empresas parceiras no papel de fornecedores, transportadoras, armazéns, além de auditores e doadores.

A fim de melhorar o entendimento do processo de doações e das atividades dos atores envolvidos na operação Mendes et al. (2017) desenvolveram um fluxo de atividades baseada na notação BPMN (Business Process Model and Notation), ilustrado na Figura 1. É importante frisar que algumas funcionalidades adicionais do software, como cadastro de voluntários, cadastro de fornecedores etc., não estão listadas neste trabalho por não ser o tema central da pesquisa. 


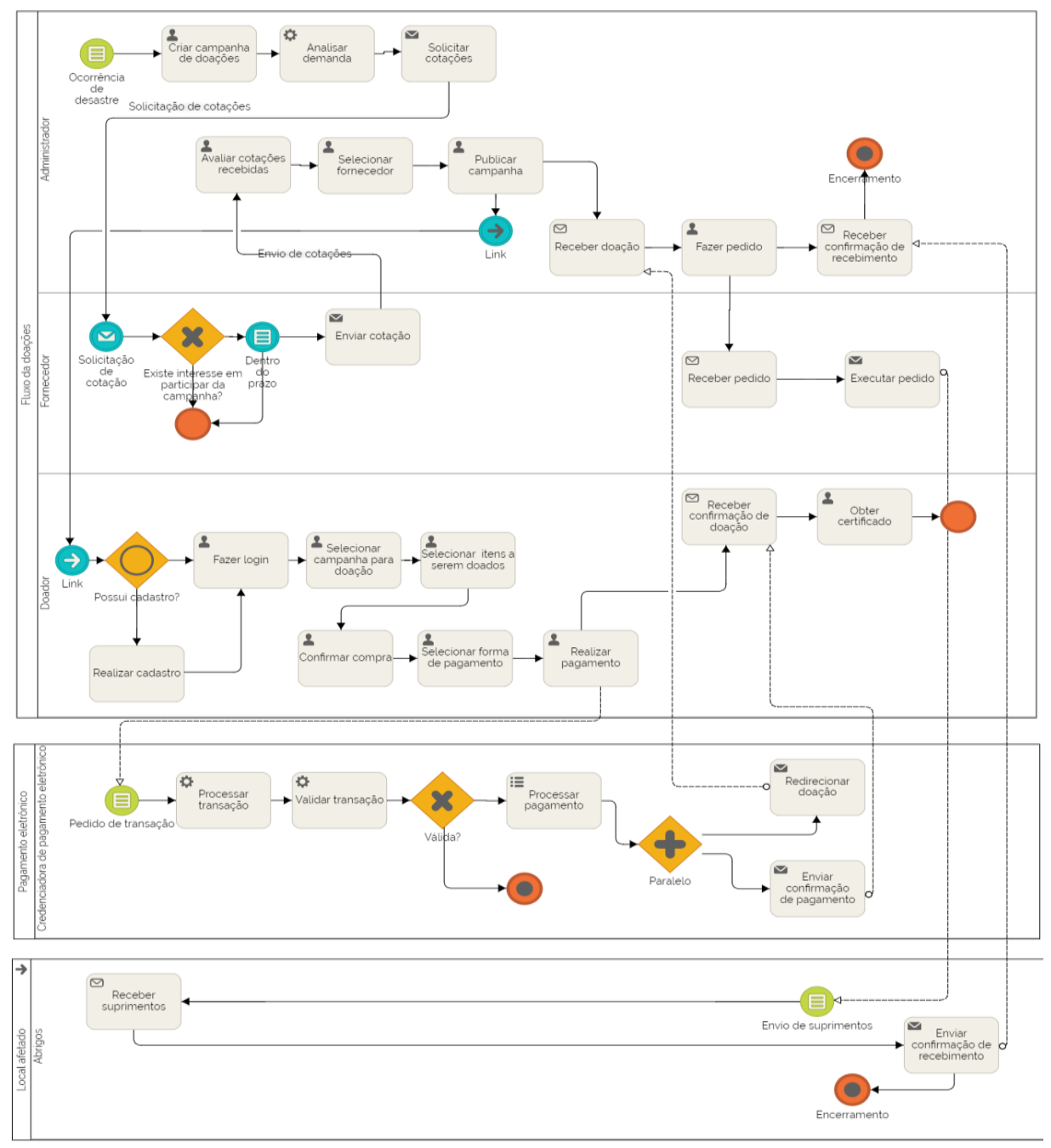

Figura 1 - Fluxo de doação (BPMN)

Fonte: Mendes et al. (2017)

\subsection{Objetivos}

Apesar da conclusão do desenvolvimento do protótipo do sistema, não se pode afirmar que o sistema é eficaz ou que pode gerar uma mudança significativa no comportamento do doador, sendo este o objetivo geral do presente trabalho: avaliar o sistema desenvolvido pela perspectiva de doadores e instituições humanitárias, evidenciando as barreiras e melhorias de oportunidade para seu desempenho e aceitação. Desta forma, visa-se responder as seguintes perguntas de pesquisa: (I) o sistema atende as funcionalidades de sistemas de gerenciamento em LH? (II) o sistema é aceito pelas instituições?; (III) o sistema é aceito pelos doadores? A pesquisa também possui os seguintes objetivos secundários: identificar na literatura as principais ferramentas utilizadas no gerenciamento de doações; caracterizar os processos de doações e aquisições 
das instituições; investigar a propensão de doação financeira pelos usuários diante do sistema; investigar os fatores que influenciam o ato de doar, bem como as preferências do doador; propor a partir da identificação de lacunas da literatura, da percepção das organizações e de potenciais doadores melhorias para o sistema.

\subsection{Justificativa da pesquisa}

Gonçalves e Lima (2018) citam como objetivos em LH, não somente a melhoraria da qualidade da assistência humanitária prestada, como também a potencialização da transparência e responsabilidade dos atores humanitários com seus participantes, doadores e com a população afetada. Para isto, é necessário que exista congruência e colaboração entre pesquisa, ensino e extensão, exigindo cada vez mais a busca por estudos empíricos aplicados e parcerias.

Özdamar e Ertem (2015) afirmam o quanto é difícil implementar procedimentos de solução na vida real sem um sistema de informação adequado que agregue modelos matemáticos e uma interface amigável. Esses sistemas têm o potencial de atuar como uma ligação entre os profissionais de $\mathrm{LH}$ e pesquisadores acadêmicos do tema e ainda ser um elo entre os diferentes estágios do ciclo de vida de desastres. Os autores ainda citam a dispersão de funcionalidade e acessibilidade das tecnologias facilitadoras desenvolvidas como barreiras a serem ultrapassadas, a fim dos sistemas serem capazes de disponibilizar métodos de solução para ajudar os profissionais de campo. Embora tenha ocorrido um crescimento nos últimos anos para integrar sistemas de informação nos modelos de LH, o uso da tecnologia ainda não é predominante na área e embora não seja fácil combinar os objetivos de profissionais de campo e pesquisadores acadêmicos, o uso da tecnologia é essencial para se obter sucesso nas operações de assistência humanitária. Chikolo (2006) enfatiza a falta de um sistema efetivo de informações logísticas que poderia ser o repositório de dados sobre a eficácia dos fornecedores e transportadoras, custo e oportunidade de resposta, adequação dos bens doados e gestão da informação.

Uma das críticas em linhas gerais dos sistemas desenvolvidos é a falta de integração entre stakeholders, que pode levar a ineficiência na assistência prestada (Leiras et al., 2014). Do ponto de vista da doação um dos passos fundamentais é tratar o doador como membro ativo e capaz de tomar decisões, levando em consideração as mudanças significativas da sociedade em relação as formas de comunicação e relacionamento. Já é seguro afirmar, que a tecnologia 
modificou não apenas as formas de comunicação e de relacionamento entre as pessoas, mas também as relações de mercado e vários ramos da economia, as formas e relações de consumo, de trabalho, de entretenimento, de educação e aprendizagem.

Dessa forma, percebe-se a relevância da avaliação e validação do sistema e motivação em estudá-lo a fim de preencher uma lacuna na literatura e melhorar a resposta a desastres.

\subsection{Estrutura do trabalho}

Este trabalho de pesquisa está organizado em capítulos, sendo o primeiro a introdução aqui apresentada. No capítulo 2 é realizada uma revisão bibliográfica abordando conceitos relevantes sobre doações, processo de compras, aspectos referentes a tomada de decisão do doador e ferramentas de avaliação de software. No capítulo 3 é apresentada a metodologia da pesquisa, já no capítulo 4 é apresentada a análise das funcionalidades do sistema. O capítulo 5 é dedicado ao estudo de caso sobre a aceitabilidades do sistema pelas organizações. No capítulo 6 é feita a apresentação dos resultados referentes a pesquisa do tipo survey. Por fim, o capítulo 7 é dedicado as conclusões, assim como as limitações do estudo e propostas de trabalhos futuros. 


\section{2 Referencial teórico}

Nesta seção é apresentada uma revisão dos principais assuntos relacionados à discussão sobre gerenciamento de doações no campo da logística humanitária e os conceitos que fundamentam a base teórica do trabalho, como: convergência de materiais, doações de alta prioridade, de baixa prioridade e não prioritárias.

\subsection{Doações}

Nesta seção são apresentados os maiores desafios no gerenciamento de doações, suas principais características e respectivas implicações.

\subsubsection{Doações não solicitadas e convergência de materiais}

Após a ocorrência de um desastre, principalmente de grande escala, uma enorme quantidade de suprimentos e equipamentos é enviada de diversas fontes diferentes. Por vezes provenientes de estoques mantidos por organizações humanitárias, contudo majoritariamente advindos de campanhas de doação organizadas por comunidades ou organizações locais (Holguín-Veras et al., 2012). Em geral o volume de doações é grande e em termos de quantidade deveria ser suficiente para suprir as necessidades dos beneficiários, contudo, pela desinformação e perfil conservador do doador, a chegada em massa de itens de assistência não significa que os itens são úteis logo após a ocorrência do desastre (Arnette e Zobel, 2016).

A Organização Pan-Americana da Saúde classifica as doações quanto ao nível de prioridade, podendo ser: (a) de alta prioridade, que são necessárias para distribuição e consumo imediatos; (b) doações de baixa prioridade, que não são imediatamente necessárias, mas podem ser úteis em estágios posteriores de recuperação; (c) e doações não prioritárias, que não deveriam ter sido enviadas para a área do desastre (Pan American Health Organization, 2001). São os fluxos não prioritários e até os de baixa prioridade que normalmente obstruem e atrasam a distribuição efetiva de itens de alta prioridade, ocasionando a convergência de 
materiais. Materiais não prioritários, se enviados em excesso, provocam impactos negativos nos acessos às áreas de desastres, sobrecarregando e congestionando o canal logístico, ocupando espaço que poderiam estocar materiais prioritários e, consequentemente, atrasam o processo de resposta ao desastre. $\mathrm{O}$ acúmulo das doações desnecessárias impede a gestão eficiente dos recursos disponíveis e, o que deveria ser um benefício, se torna um transtorno às equipes de apoio. Alguns autores consideram o gerenciamento de doações uma das maiores dificuldades em operações humanitárias (Meirim, 2012; Gregório, 2012; Leiras et al., 2014).

No que tange o tipo de doações feitas no Brasil, grande parte das doações é concentrada em roupas e calçados, segundo um levantamento apresentado na Semana de Ciência e Tecnologia da USP sobre impactos das doações de materiais em desastres (USP, 2017). Ainda, segundo o mesmo estudo, alimentos também são doados, porém em quantidade insuficiente para atendimento à população afetada. Produtos de limpeza raramente são doados, porém são necessários principalmente em inundações. Para exemplificar estes problemas pode-se citar o desastre de São Luiz do Paraitinga em 2010, o município que possuía uma população de 10.397 habitantes, e recebeu 340.000 itens de vestuário em doações. Este montante correspondia a 32,7 itens para cada habitante, um excesso que é descartado após longo período sem utilização. Outro aspecto relevante sobre doações é o estímulo provocado pela extensa cobertura de mídia, como ocorrido no terremoto do Haiti, em 2010, proporcionando uma grande quantidade de materiais não solicitados, que congestionaram os canais logísticos, gerando gargalos e dificuldades no manuseio de materiais realmente necessários, com consequentes atrasos na operação de resposta.

\subsubsection{Doações monetárias $x$ doações materiais}

Em geral, a população não está familiarizada com o que acontece em uma operação de resposta humanitária e pode pensar que seus produtos doados (embora não solicitados) ajudarão a população afetada. No entanto, a realidade no campo é que esses bens ocupam um tempo precioso e recursos humanos escassos para descarregar, classificar, armazenar e distribuir ou descartar. Uma vez descarregados, essas doações ficam em áreas de preparação, obstruindo o espaço necessário para abastecer suprimentos que salvam vidas. Os recursos dedicados a esse propósito são extraídos em detrimento da atenção aos sobreviventes e programas que os apoiam. Em alguns casos, esses produtos 
indesejados, inadequados e geralmente inutilizáveis compõem a maioria do total de materiais doados (Holguín-Veras et al., 2012).

O problema é tão sério que o chamam de "o segundo desastre" (Starr e Van Wassenhove, 2014). Contudo, por medo da possibilidade de perder doações futuras, organizações de ajuda humanitária em geral não estão dispostas a rejeitar doações não solicitadas. Como alternativa, há um impulso crescente na comunidade humanitária para doações em dinheiro, uma vez que o dinheiro proporciona a essas organizações uma flexibilidade importante em suas operações (Harvey e Bailey, 2011). O público em geral, por outro lado, em parte devido à falta de familiaridade com o setor e parcialmente devido a questões sobre a transparência financeira de ONGs individuais, pode relutar em doar em dinheiro. Alexander (2013) destaca o fato de que a comunidade de doadores ainda está preocupada sobre como seu dinheiro será usado por organizações de ajuda humanitária, o que demonstra a necessidade de engajamento público adicional através de ferramentas educacionais.

Embora os desafios de administrar doações materiais sejam mais visíveis na resposta a desastres, elas são difíceis de gerenciar, mesmo em contextos não relacionados a desastres. Islam (2013) frisa alguns problemas enfrentados por organizações, que passam pelo dilema entre receber itens com baixa urgência e continuar usando recursos humanos limitados esperando encontrar doações apropriadas no decorrer de campanhas ou evitar completamente doações materiais e concentrar sua mão de obra limitada na compra de suprimentos necessários com recursos financeiros limitados. $O$ autor ainda cita o aumento e fragmentação da rede de ajuda compostas por ONGs que respondem a desastres, e o maior o número de doadores que doa cada vez mais suprimentos, tendo como resultado, o recebimento de grande quantidade de doações. Outra dificuldade apontada pelo autor é o desafio de transportar suprimentos doados. A maioria dos doadores não está disposta a pagar pelo transporte, esperando ainda que a ONG beneficiária retire os produtos - geralmente em prazo relativamente curto, gerenciando e pagando pelo seu transporte, armazenamento e distribuição. Isto faz com que, na prática, as ONGs tenham que decidir entre pagar pelo transporte de bens doados, que podem não corresponder perfeitamente às suas necessidades, e comprar suprimentos mais adequados, mas também mais caros, no mercado aberto. Segundo Özpolat et al. (2015) essa decisão é complicada pela constatação de que a compra local oferece o benefício secundário de apoiar a economia local, sendo este um dos argumentos mais fortes contra a importação de doações materiais de fora do país em resposta a desastres internacionais, o 
que pode potencialmente destruir o mercado local de commodities específicos. Por outro lado, os desastres em grande escala podem reduzir a disponibilidade de itens-chave e elevar os preços locais para níveis inacessíveis. Silva e Leiras (2015) apontam outro aspecto importante a ser considerado em termos de doações: a avaliação de doadores. Esta abordagem pouco explorada na literatura, pode ser uma forma de propor melhores estratégias de captação e fidelização de doadores.

\subsubsection{Avaliação sob a perspectiva dos doadores}

Mapear e entender o comportamento do doador é uma importante medida para as instituições humanitárias e organizações da sociedade civil para promover um maior engajamento da sociedade. Em 2015, o Instituto para o Desenvolvimento do Investimento Social (IDIS) promoveu a PDB - Pesquisa Doação Brasil (IDIS, 2015), a primeira de abrangência nacional sobre os hábitos do doador no país. Entre os principais achados da pesquisa destacam-se: a percepção dos brasileiros em relação a responsabilidade pela resolução de problemas sociais ser do Governo; e a constatação da desconfiança dos brasileiros pelas instituições. Contudo, apesar da desconfiança cerca de $46 \%$ dos brasileiros doaram dinheiro para instituições sociais em 2015, tendo como quantia típica (mediana) o valor de $\mathrm{R} \$ 240 / a n o$. Já em 2017, representando a Charities Aid Foundation no Brasil e a fim de ser capaz de comparar os resultados com outros países através do World Giving Index (Índice Global de Solidariedade), aplicou-se outra metodologia, o CGR - Country Giving Report (IDIS, 2017), que oferece uma visão de como as pessoas doam, em diferentes idades e grupos sociais, em diferentes países; a forma como doam; o aumento das doações online ou por mensagem de texto; a importância do patrocínio (sem interesse comercial) e as diferentes causas apoiadas. Entre os principais resultados destacam-se: o número de pessoas pesquisadas que afirmou ter doado a uma organização social, que foi de $68 \%$; além dos $52 \%$ que afirmaram ter feito algum tipo de trabalho voluntário. Outro fator importante foi a quantia de $\mathrm{R} \$ 250$ doada (mediana) anualmente e a forma de doação, sendo mais recorrente em dinheiro entregue na própria instituição (37\%).

Apesar de não utilizarem a mesma base de perguntas e metodologia, existem perguntas similares que podem ser comparadas. Avaliando as duas pesquisas é possível observar ainda algumas mudanças na percepção da maioria quanto a motivação. Na PDB, a majoritária motivação para doação em dinheiro é, 
segundo os respondentes, a solidariedade com os mais necessitados (IDIS, 2015). Enquanto na CGR é, segundo os respondentes, o fato de sentir-se bem (IDIS, 2017). Em ambas as pesquisas o fator mais citado para incentivo a maiores doações ou bens é "ter mais dinheiro" (IDIS, 2015; 2017). Essas pesquisas mostram como é relevante entender o comportamento do doador e suas motivações para as organizações serem capazes de responder de maneira efetiva as expectativas do doador e dessa forma, captarem mais fundos. Apesar da relevância internacional trazida pela CGR, a PDB mostra-se mais completa do ponto de vista da pesquisa acadêmica pois, além das motivações internas e externas para doação, também aborda para as não-doações.

Para a compreensão do comportamento do doador, um objetivo fundamental é o estudo das atitudes e das preferências, já que são importantes determinantes do ato de doar (Certo, 2003). Para Backer e Costa (1995), atitudes são um estado mental de prontidão aprendido, uma maneira pela qual indivíduos constroem seus próprios mundos de modo que, quando confrontados com um estímulo, agem de uma certa maneira. No campo da logística humanitária existem alguns trabalhos que visam prever o comportamento do doador. Oosterhof, Heuvelman e Peters (2009) expõem fatores cognitivos sociais subjacentes para doação a campanhas com um modelo causal baseado na pesquisa de atitudes e no impacto da exposição na mídia. Huber et al. (2011) discutem o viés do imediatismo na tomada de decisão de doação através de experimentos nos quais os participantes são expostos à diferentes tipos de desastres e devem decidir para quais desastres doar, como resultado o desastre mais "recente" era o que apresentava maior quantidade de doações. Zagefka et al. (2011) também discutem a influência dos tipos de desastres na tomada de decisão, mas sem levar o viés do imediatismo em consideração. No estudo, mais doações foram provocadas por desastres causados naturalmente e não por causas humanas. Essa diferença foi motivada por uma percepção de que as vítimas de desastres naturais devem ser menos culpadas por sua situação difícil e que elas se esforçam mais para ajudar a si mesmas.

Da Costa, Daré e Veloso (2004) buscaram identificar as variáveis envolvidas no processo decisório de um indivíduo que doa recursos financeiros a entidades sem fins lucrativos, adaptando conceito de marketing do comportamento do consumidor de modo que fosse possível identificar os fatores envolvidos no processo e elaborar um modelo do comportamento do doador, identificando, além disso, possíveis fatores responsáveis pela não doação. Segundo os autores, o processo decisório é constituído por 3 etapas fundamentais: decisão de doar; 
busca de informações; doação de recursos e pós-doação. O processo de doação tem início por meio da influência das ferramentas de mídia e do círculo de relacionamentos, apresentando papel significativo ao promover estímulos à percepção do indivíduo de que há causas e entidades que dependem de sua ajuda para promover ações sociais. Assim, conjuntamente a aspectos intrínsecos a cada ser humano, como preocupação social e satisfação pessoal, acabariam por incentivá-lo a avaliar a possibilidade de contribuição para uma causa ou entidade específica. Em seguida, o potencial doador incorre na busca de informações acerca das atividades desenvolvidas pela da entidade em questão. Além das fontes de informação advindas da mídia e do círculo de relacionamentos pessoais, consideram aquelas da própria instituição (panfletos, websites etc.). Dessa forma, o indivíduo procura avaliar a transparência das ações e dos objetivos da organização, por meio de identificação de tipos de controles de suas atividades e das técnicas de captação de fundos utilizadas. Em suma, nesta etapa do processo, busca-se atestar a confiabilidade da organização. Uma vez tomada a decisão de realizar a doação, o doador utiliza-se de um conjunto de meios de pagamentos para fazê-lo (no caso de doações monetárias). Após a realização da doação, o indivíduo avalia os resultados de sua ação, buscando dois tipos de informações para alicerçar suas percepções: busca ativa, na qual o doador procura a entidade para obter maiores informações sobre o desempenho alcançado com os recursos doados; ou busca passiva, utilizando-se das divulgações das atividades da organização na mídia (jornais, revistas, websites etc.). A última etapa refere-se à avaliação da satisfação pessoal, realizada por meio da comparação entre as expectativas anteriores à doação e os resultados de sua ação. Neste sentido, fatores como transparência das atividades, forma de atuação e utilização dos recursos, manutenção de um relacionamento com a entidade e abordagem para coleta de contribuições exercem influência direta em sua satisfação. Segundo os autores, o ciclo seria realimentado, tendo a satisfação em experiências anteriores como um dos fatores subjacentes que estimulariam novas doações.

\subsection{Processo de compras e aquisição}

O processo de compras em logística humanitária é definido por Ertem e Buyurgan (2011) como a aquisição de bens ou equipamentos de socorro pelas organizações mediante pagamentos monetários aos fornecedores. É um dos primeiros e talvez o passo mais negligenciado nas operações humanitárias, 
apesar de ser um dos processos mais caros. Algumas estimativas mostram que $65 \%$ do orçamento total de resposta a desastres é dedicado à aquisição de suprimentos e equipamentos (Schulz, 2009), onde a maior parte do financiamento dos doadores é gasto.

A atividade de compras é fundamental em operações humanitárias já que o pré-posicionamento de estoques e as doações materiais recebidas, em geral, não são suficientes ou adequadas para atender toda a demanda criada por um desastre ou situação de risco (Ertem et al., 2010). O processo de aquisição visa identificar os bens, equipamentos e serviços necessários para a implementação das operações. É necessário identificar esta necessidade operacionalmente no momento certo para uma operação específica, na quantidade correta que corresponde às necessidades, e na qualidade que atenda às especificações mínimas para condições específicas da operação, levando também em consideração custo, prazo e qualidade (Blecken, 2010).

Os métodos de compra podem ser classificados em duas dimensões: localização dos fornecedores e tempo de aquisição, podendo ser feitas a nível local ou global. Segundo Herlin e Pazirandeh (2012) existem os grandes compradores, que devido a seu volume de compras, larga atuação em diversos desastres, reputação e marcas reconhecidas globalmente, possuem um grande poder de barganha e desenvolvimento de relações com os fornecedores globais e com grande capacidade. Já os compradores menores, como ONGs locais, geralmente lidam com um número limitado de fornecedores nos mercados locais, apresentando uma forte dependência e possuem um pequeno poder de compra e poder de barganha com fornecedores. Dessa forma, grande parte dos pequenos compradores terceiriza suas compras para os grandes compradores aproveitando seu alto poder de compra para obter preços e condições mais vantajosas. Este comportamento é identificado em desastres de grande escala, já que a depender da capacidade de resposta local, a ajuda internacional não é necessária. Portanto é fundamental desenvolver a área de compras de organizações locais com políticas e procedimentos bem definidos, critérios estabelecidos para avaliação, além de ferramentas e sistemas (Fudalinski e Pawlak, 2012).

Dada a dificuldade de coordenação e necessidade de fornecimento de ajuda no menor tempo possível, a adoção de um modelo de processos pode colaborar para a condução do planejamento e execução de procedimentos cruciais para as organizações humanitárias. Blecken (2010) identifica e separa as etapas por níveis estratégico, tático e operacional, Já Fontainha et al. (2018) sintetizam as principais tarefas associadas à solicitação de recursos durante a resposta e 
propõe um modelo de processos, com níveis bem definidos. Além dos dois autores citados, são consideradas também as etapas definidas pelo LOG - Logistics Operational Guide (2015), projetado para ser uma fonte única de melhores práticas, incluindo modelos logísticos, ferramentas operacionais, referências e diretrizes que devem ser úteis para todos os profissionais envolvidos em operações humanitárias, independentemente do tamanho de sua organização ou de sua área de especialização. A inclusão deste modelo é importante pela importância no campo prático em operações humanitárias.

As etapas definidas por Fontainha et al. (2018) e as definidas pelo LOG (2015) são relacionadas a fase de resposta, enquanto Blecken (2010) as divide em níveis de planejamento estratégico, tático e operacional. O último nível é o mais próximo da fase correspondente dos demais modelos, por isso somente esse nível é considerado ao comparar as etapas entre os três. Um ponto a ser ressaltado é que Fontainha et al. (2018) utilizam na construção de seu modelo de processos várias fontes advindas de uma revisão sistemática da literatura, incluindo Blecken (2010), o que garante que todas as etapas identificadas pelo autor a nível operacional são consideradas, com a vantagem de ter todas as etapas em ordem com precedência e sucessão bem definidas. Todos as etapas são apresentadas no Quadro 1 com uma breve descrição de cada uma delas e suas respectivas fontes. As três primeiras etapas do Logistics Operational Guide referem-se ao levantamento, identificação de necessidades e planejamento, que não estão definidas no processo de aquisição de recursos de Fontainha et al. (2018). Outras etapas que não estão definidas no modelo de Fontainha et al. (2018) são "Identificar Fontes"; "Avaliar e escolher"; "Expedir entrega" e "Revisar e agir". Já as etapas "Especificar recursos financeiros"; "Especificar recursos humanos" e "Especificar produtos especiais" são detalhamentos da etapa "Especificar" do guia. As etapas "Comprar produtos locais e externos" e "Emitir ordem de compra" são equivalentes. Os modelos são complementares e todas as etapas foram consideradas como referência, exceto as equivalentes, caso em que somente uma delas é considerada. 
Quadro 1 - Tarefas relacionadas ao processo de aquisição em LH

\begin{tabular}{|c|c|c|}
\hline Etapas & Descrição & Fontes \\
\hline Avaliar situação & $\begin{array}{l}\text { Levantar a situação inicial, infraestrutura, número de } \\
\text { pessoas afetadas etc. }\end{array}$ & LOG (2015) \\
\hline $\begin{array}{l}\text { Identificar } \\
\text { necessidades }\end{array}$ & Determinar os recursos e suas características essenciais. & LOG (2015) \\
\hline $\begin{array}{l}\text { Priorizar } \\
\text { necessidades }\end{array}$ & $\begin{array}{l}\text { Estabelecimento de ordem de prioridade para } \\
\text { necessidades observadas. }\end{array}$ & $\begin{array}{l}\text { Fontainha et al. } \\
\text { (2018) }\end{array}$ \\
\hline Planejar aquisições & $\begin{array}{l}\text { Desenvolver o plano sobre como entregar o serviço ou os } \\
\text { bens necessários. Deve ser desenvolvido } \\
\text { colaborativamente, para que seja integrado na estratégia } \\
\text { da organização e fornecido adequadamente }\end{array}$ & LOG (2015) \\
\hline Identificar Fontes & $\begin{array}{l}\text { Identificação de fontes de suprimentos e acesso as } \\
\text { capacidades do fornecedor. Implica também na decisão } \\
\text { dos tipos dos processos internos para avaliação, se por } \\
\text { propostas, cotação, etc. }\end{array}$ & LOG (2015) \\
\hline $\begin{array}{l}\text { Encomendar } \\
\text { produtos } \\
\text { emergenciais }\end{array}$ & Encomenda dos suprimentos prioritários & $\begin{array}{l}\text { Fontainha et al. } \\
(2018)\end{array}$ \\
\hline $\begin{array}{l}\text { Especificar } \\
\text { produtos especiais }\end{array}$ & $\begin{array}{l}\text { Detalhamento e caracterização produtos fora dos } \\
\text { produtos padrão }\end{array}$ & $\begin{array}{l}\text { Fontainha et al. } \\
(2018)\end{array}$ \\
\hline $\begin{array}{l}\text { Pedir produtos } \\
\text { emergenciais em } \\
\text { estoque }\end{array}$ & $\begin{array}{l}\text { Verificação e requisição de produtos prioritários } \\
\text { estocados }\end{array}$ & $\begin{array}{l}\text { Fontainha et al. } \\
(2018)\end{array}$ \\
\hline $\begin{array}{l}\text { Especificar } \\
\text { recursos humanos } \\
\text { necessários }\end{array}$ & $\begin{array}{l}\text { Detalhamento de quais habilidades ou especialidades } \\
\text { voluntários e/ou profissionais devem possuir, bem como } \\
\text { especificar o efetivo necessário }\end{array}$ & $\begin{array}{l}\text { Fontainha et al. } \\
(2018)\end{array}$ \\
\hline $\begin{array}{l}\text { Especificar } \\
\text { recursos } \\
\text { financeiros } \\
\text { necessários }\end{array}$ & $\begin{array}{l}\text { Determinar qual o valor necessário para a operação, e } \\
\text { identificar fontes desses recursos }\end{array}$ & $\begin{array}{l}\text { Fontainha et al. } \\
(2018)\end{array}$ \\
\hline $\begin{array}{l}\text { Realizar cotação } \\
\text { de produtos }\end{array}$ & $\begin{array}{l}\text { Abrir processo de levantamento de preços entre } \\
\text { fornecedores }\end{array}$ & $\begin{array}{l}\text { Fontainha et al. } \\
(2018)\end{array}$ \\
\hline $\begin{array}{l}\text { Realizar cotação } \\
\text { de recursos de } \\
\text { transporte }\end{array}$ & $\begin{array}{l}\text { Abrir processo de levantamento de preços entre } \\
\text { transportadores }\end{array}$ & $\begin{array}{l}\text { Fontainha et al. } \\
(2018)\end{array}$ \\
\hline $\begin{array}{l}\text { Consolidar } \\
\text { solicitação } \\
\text { produtos }\end{array}$ & Finalizar a requisição de produtos com os fornecedores & $\begin{array}{l}\text { Fontainha et al. } \\
(2018)\end{array}$ \\
\hline $\begin{array}{l}\text { Mobilizar recursos } \\
\text { nos armazéns de } \\
\text { fornecedores }\end{array}$ & $\begin{array}{l}\text { Mobilizar os recursos provenientes de armazéns de } \\
\text { fornecedores }\end{array}$ & $\begin{array}{l}\text { Fontainha et al. } \\
(2018)\end{array}$ \\
\hline $\begin{array}{l}\text { Mobilizar recursos } \\
\text { nos armazéns } \\
\text { estratégicos }\end{array}$ & $\begin{array}{l}\text { Mobilizar os recursos provenientes de armazéns } \\
\text { estratégicos }\end{array}$ & $\begin{array}{l}\text { Fontainha et al. } \\
(2018)\end{array}$ \\
\hline $\begin{array}{l}\text { Comunicar as } \\
\text { prioridades aos } \\
\text { doadores }\end{array}$ & Informar de maneira simples as necessidades prioritárias & $\begin{array}{l}\text { Fontainha et al. } \\
(2018)\end{array}$ \\
\hline Receber doações & Receber os recursos provenientes de doações & $\begin{array}{l}\text { Fontainha et al. } \\
\text { (2018) }\end{array}$ \\
\hline
\end{tabular}

(continua) 
Quadro 1 - Final

\begin{tabular}{|l|l|l|}
\hline $\begin{array}{l}\text { Justificar } \\
\text { solicitações } \\
\text { especiais }\end{array}$ & $\begin{array}{l}\text { Evidenciar e documentar todos as solicitações de itens } \\
\text { não padronizados }\end{array}$ & $\begin{array}{l}\text { Fontainha et al. } \\
(2018)\end{array}$ \\
\hline $\begin{array}{l}\text { Confirmar e validar } \\
\text { compra (local e } \\
\text { externa) }\end{array}$ & Verificar os pedidos feitos a fim de minimizar erros & $\begin{array}{l}\text { Fontainha et al. } \\
(2018)\end{array}$ \\
\hline $\begin{array}{l}\text { Comprar produtos } \\
\text { locais e externos }\end{array}$ & Emitir ordem de compra & $\begin{array}{l}\text { Fontainha et al. } \\
(2018)\end{array}$ \\
\hline $\begin{array}{l}\text { Contratar recursos } \\
\text { de transporte }\end{array}$ & $\begin{array}{l}\text { Realizar a contratação de serviços de transporte } \\
\text { Avaliar e escolher } \\
\text { definidos, requisitos de especificação e análise, } \\
\text { verificação da capacidade do fornecedor e garantia de } \\
\text { qualidade; verificação de relatórios de avaliação técnica, } \\
\text { quando aplicável. Escolha, elaboração do pedido e } \\
\text { contrato, se aplicável. }\end{array}$ & $\begin{array}{l}\text { Fontainha et al. } \\
(2018)\end{array}$ \\
\hline $\begin{array}{l}\text { Expedir e monitorar } \\
\text { entrega }\end{array}$ & $\begin{array}{l}\text { Recebimento físico e inspeção de mercadorias de acordo } \\
\text { com os requisitos do contrato no ponto de entrega. Nesta } \\
\text { etapa também é, em geral, liberado o pagamento. }\end{array}$ & $\begin{array}{l}\text { Fontainha et al. } \\
(2018) ; \\
(2015)\end{array}$ \\
\hline Revisar e agir & $\begin{array}{l}\text { Revisão com o usuário ou beneficiário original se as } \\
\text { necessidades foram atendidas; revisão do desempenho } \\
\text { da aquisição na execução do processo e uma revisão do } \\
\text { desempenho do fornecedor. Esta etapa de revisão } \\
\text { acontece muito mais tarde na emergência. }\end{array}$ & \begin{tabular}{l} 
LOG (2015) \\
\hline
\end{tabular} \\
\hline
\end{tabular}

Todas as etapas mostradas no Quadro 1, são base para a modelagem dos processos de compra das instituições, e são um importante direcionador dos níveis de maturidade dos processos de aquisição de suprimentos.

\subsection{Avaliação de software}

A avaliação da qualidade de software pode ser realizada em dois momentos: durante a geração do software e após este estar pronto para o uso, chamando esses dois momentos, respectivamente, de processo e produto. No primeiro momento procura-se avaliar de que forma o software está sendo desenvolvido, identificando práticas que possam conduzir a problemas na qualidade do produto e desenvolvendo e/ou utilizando métodos e ferramentas que evitem esses problemas. No segundo momento, com o produto concluído, procura-se avaliar a sua qualidade a fim de identificar deficiências e limitações em sua aplicabilidade como um produto final (Silva, 2003).

Cybis, Betiol e Faust (2015) afirmam que a satisfação do usuário e os retornos econômicos são considerações importantes para avaliar a eficácia de um sistema de software. O número de fatores tangíveis e intangíveis complexos envolvidos requerem uma abordagem com múltiplos pontos de vista para a avaliação, portanto, organizar a multiplicidade de fatores de acordo com diferentes 
pontos de vista (os de desenvolvedores, operadores e usuários) facilita a seleção de métricas importantes para a avaliação do sistema de software. Em geral, um conjunto completo de funcionalidades não é suficiente para garantir o sucesso de um software, é a qualidade que determina se ele pode ser considerado um sucesso ou um fracasso (Larman, 2012).

Nielsen (1994) define aceitabilidade geral de um sistema como a combinação de sua aceitabilidade social e aceitabilidade prática. A primeira citada trata de um conceito mais subjetivo dos usuários, levando em conta aspectos cognitivos e comportamentais, enquanto a segunda trata dos tradicionais parâmetros de custo, confiabilidade, compatibilidade com sistemas existentes, etc. Tal estrutura é detalhada na Figura 2.

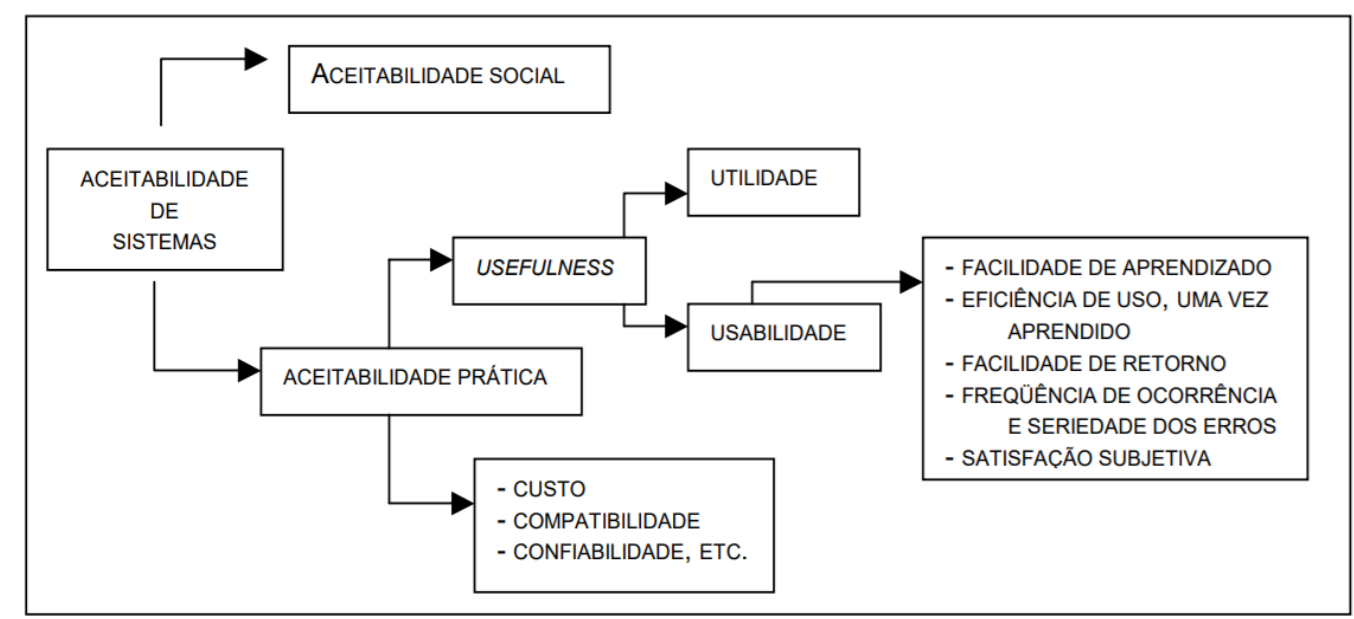

Figura 2 - Atributos de aceitabilidade de sistemas

Fonte: Adaptado de Nielsen, 1994

O objetivo da análise é fornecer sistemas usuais, seguros e funcionais, desenvolvendo ou melhorando sua segurança, utilidade, efetividade $e$ usabilidade, ajudando as pessoas a executarem suas atividades produtivamente, com segurança, sem precisar mudar radicalmente para se adequar ao sistema, pois é o sistema que deve ser projetado para se adequar aos requisitos. No que tange a aceitabilidade social o ideal é que seja avaliada pelos usuários finais do sistema a fim de captar as impressões reais do mesmo, enquanto a aceitabilidade prática utiliza métricas mais bem definidas e objetivas. O foco nos dois tipos de avaliação pode ser com usuários distintos a depender de seu grau de iteração e acesso a funcionalidades.

Ainda considerando os atributos definidos por Nielsen, para além dos tradicionais parâmetros de custo, confiabilidade e compatibilidade, define-se 
usefulness quando o sistema é considerado suficiente para atingir um determinado objetivo. Essa categoria é uma combinação de duas outras: utilidade e usabilidade. Utilidade deve verificar se a funcionalidade do sistema faz aquilo a que se propos. Usabilidade é a questão relacionada a quão bem os usuários podem usar a funcionalidade definida e este é um conceito chave na Interação Homem-Computador (IHC). A aceitabilidade de um sistema tem muitos componentes e fundada na crença de que o centro e ponto básico de análise são as pessoas usando um sistema computacional. Suas necessidades, capacidades e preferências para executar diversas tarefas devem informar os meios como os sistemas devem ser projetados e implementados. (Vieira e Baranauskas, 2003).

Na próxima subseção são mostradas algumas formas de avaliar um produto de software na literatura, em sua totalidade ou em atributos específicos.

\subsubsection{NBR ISO/IEC 9126}

Uma das possibilidades de elaboração de análise da qualidade é através de padrões e métodos. No que tange a qualidade de software o conjunto de normas é dado pela NBR ISO/IEC9126 "Engenharia de Software - Qualidade do Produto" (ABNT, 2003). A norma é dividida em quatro partes: modelo de qualidade; métricas externas; métricas internas; métricas em qualidade de uso.

O modelo de qualidade é definido como o relacionamento e características que fornecem a base para especificação dos requisitos e avaliação de qualidade. Inclui qualidade interna, qualidade externa e em uso.

Qualidade interna é definida como a totalidade das características do produto de software do ponto de vista interno. Detalhes da qualidade do produto de software podem ser melhorados durante a implementação do código, revisão e teste, mas a natureza fundamental da qualidade do produto de software representada pela qualidade interna mantém-se inalterada, a menos que seja reprojetada.

Qualidade externa é definida como a totalidade das características do produto de software do ponto de vista externo. É a qualidade quando o software é executado, o qual é tipicamente medido e avaliado enquanto está sendo testado num ambiente simulado, com dados simulados e usando métricas externas. Durante os testes, convém que a maioria dos defeitos seja descoberta e eliminada. Entretanto, alguns defeitos podem permanecer após o teste. Como é difícil corrigir a arquitetura do software ou outro aspecto básico do projeto do software, a base do projeto usualmente permanece inalterada ao longo do teste. 
Qualidade em uso é definida como a visão do usuário no ambiente do software. Esta parte da norma permite a avaliação da qualidade do produto final desenvolvido através de um conjunto de características que devem ser verificadas, e certificam o produto de software quanto à sua qualidade. Algumas das características são:

- Funcionalidade - Conjunto de atributos que evidenciam a existência de um conjunto de funções e suas propriedades especificadas. As funções são as que satisfazem as necessidades explícitas e implícitas.

- Confiabilidade - Conjunto de atributos que evidenciam a capacidade do software de manter seu nível de desempenho sob condições estabelecidas durante um período de tempo estabelecido.

- Usabilidade - Conjunto de atributos que evidenciam o esforço necessário para se poder utilizar o software, bem como o julgamento individual desse uso, por um conjunto explícito ou implícito de usuários.

- Eficiência - Conjunto de atributos que evidenciam o relacionamento entre o nível de desempenho do software e a quantidade de recursos usados, sob condições estabelecidas.

- Manutenabilidade - Conjunto de atributos que evidenciam o esforço necessário para fazer modificações especificadas no software.

- Portabilidade - Conjunto de atributos que evidenciam a capacidade do software de ser transferido de um ambiente para outro.

\subsubsection{Atributos específicos - Usabilidade}

Apesar dos demais atributos serem fundamentais para avaliação do software, quando se avalia a qualidade do produto de software já desenvolvido, algumas avaliações de atributos tornam-se extremamente diretas e com pouca necessidade de métricas específicas para se chegar a um diagnóstico final. A funcionalidade do sistema, por exemplo, como já citado anteriormente, corresponde a capacidade do software de atender as necessidades apresentadas. O sistema desenvolvido não foi criado para atender a um cliente específico, o que dificulta a customização e adequação às necessidades individuais de uma entidade, por essa razão e por não existir técnicas bem estabelecidas para o diagnóstico desta característica como é o caso da usabilidade, ela será avaliada subjetivamente, o que justifica a maior ênfase pela revisão da literatura da usabilidade. 
Usabilidade é definida como a capacidade de um produto ser utilizado por usuários específicos para atingir objetivos específicos com eficácia, eficiência e satisfação em um contexto específico de uso (ABNT, 2011). Segundo Santa Rosa e Marques (2014) usabilidade é o conjunto de múltiplos conceitos, como tempo de execução, desempenho, satisfação do usuário e facilidade de aprendizado ("capacidade de aprendizado"), considerados em conjunto. A importância da usabilidade tem sido reconhecida pela academia e pela indústria, devido ao seu potencial para causar um impacto significativo na qualidade e, portanto, no sucesso de um software (Abran et al., 2003). É, portanto, uma qualidade básica relativa à produtividade e aceitação do software.

Os componentes da usabilidade, segundo Nielsen (1994) são: fácil aprendizado; eficiência; fácil de ser lembrado; minimização de erros e satisfação.

Estudos sobre usabilidade são comuns em aplicações como, softwares educacionais (Silius e Tervakari, 2003; Hwang et al., 2012; Avila et al., 2016), sistemas médicos (Filardi e Traina, 2008; Berk et al., 2013; Alves, 2016), sendo amplamente difundida também nos estudos de ergonomia (Molano, Yara e García, 2015; Almeida, 2016; Sanz et al., 2016; Costa, 2017).

A avaliação pode ser realizada através de diferentes tipos de instrumentos, e os principais métodos são listados a seguir (Shneiderman,1998):

- Revisões Especializadas - Requer a participação de um especialista com domínio das questões de usabilidade, do assunto ou da interface em questão. Os principais métodos são: avaliação heurística; revisão usando guias de recomendações e inspeção de consistência; navegação cognitiva; inspeções formais.

- Testes e Estudos laboratoriais - Corresponde à observação da interação de usuários no mundo real ou sob condições controladas. Os avaliadores reúnem os dados dos problemas detectados no uso e verificam se a interface suporta o ambiente e as tarefas do usuário.

- Pesquisas de Opinião - As entrevistas e questionários permitem ao avaliador de usabilidade conhecer as experiências, opiniões e preferências dos usuários ao utilizarem um determinado sistema. A partir de perguntas formuladas de acordo com o objetivo do teste, o avaliador interage com os usuários diretamente, no caso de entrevistas, facilitando a discussão sobre os temas sugeridos pelas perguntas, ou envia um questionário e aguarda suas respostas, sem interagir com os usuários participantes do teste. 
- Questionários específicos - Existem, ainda métodos de avaliação de usabilidade no campo da Interação Humano-Computador, que envolvem a participação direta de usuários para a coleta de dados. Para avaliação existem diversos instrumentos desenvolvidos e padronizados, e largamente utilizados na indústria e na academia, a fim de trazer mais consistência e facilidade na avaliação de softwares.

Os tipos genéricos (que podem ser aplicados em qualquer tipo de aplicação de software) são centrados na perspectiva do usuário final, e alguns dos mais comumente utilizados são: QUIS (Questionnaire for User Interaction Satisfaction); SUS (Software Usability Measurement Inventory); TAM (Technology Acceptance Model); PSSUQ (Post Study System Usability Questionnaire). Existem outros diversos tipos de questionários específicos e padronizados além dos citados. Assila e Ezzedine (2016) apresentam uma revisão com os principais instrumentos, algumas classificações e principais estudos comparativos já realizados. A análise comparativa realizada pelos autores é resumida no Gráfico 1. Neste trabalho de pesquisa, por se tratar de um sistema já desenvolvido e com um público-alvo bem definido e relativamente restrito opta-se pelo questionário que garante a maior cobertura quantitativa de critérios de usabilidade, o SUMI, além de aliar o formato de escala dicotômica, na qual o usuário concorda ou discorda de uma determinada sentença, que favorece a celeridade nos testes. É importante ressaltar que o maior número de critérios não significa que um determinado instrumento é melhor que outro, isso vai depender do objetivo de cada teste, da disponibilidade de tempo e perfil de cada um dos usuários.

Gráfico 1 - Critérios de qualidade e usabilidade dos questionários

- Critérios de Qualidade $\quad$ Critérios de Usabilidade

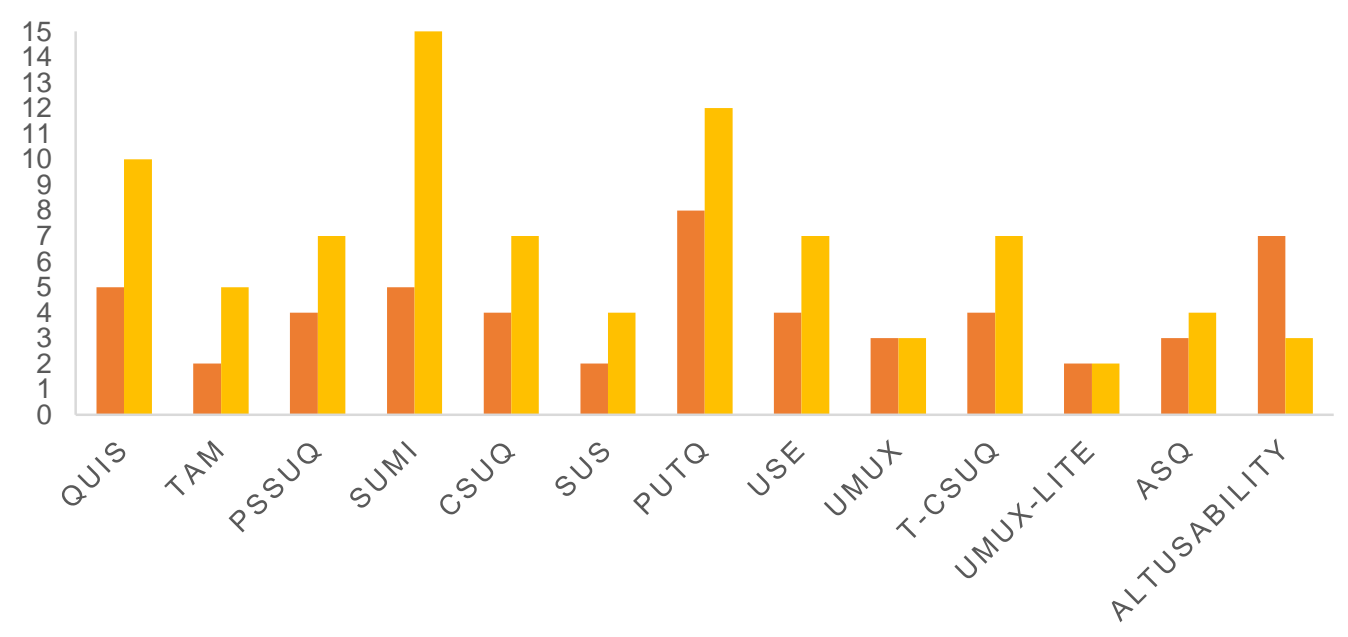

Fonte: Adaptado de Assila e Ezzedine (2016) 


\section{3 \\ Metodologia}

Nesta seção são apresentados os métodos que serão utilizados neste trabalho e o embasamento para escolha dos mesmos para a pesquisa. Deste modo, são apresentados o método de Revisão Sustemática da Literatura (RSL); de estudo de caso e a pesquisa tipo survey.

\subsection{Revisão Sistemática da Literatura (RSL)}

RSL é descrita por Thomé et al. (2016) como um método de pesquisa que avalia contribuições, mostrando o que é conhecido ou não na literatura. Esta seção visa, através desse método, mostrar as ferramentas existentes que buscam a resolução do problema da ingerência de doações que abordem diretamente este importante elo da cadeia de suprimentos humanitária.

O método é composto por oito etapas definidas por Thomé et al. (2016): planejamento e formulação do problema; busca na literatura; coleta de dados; avaliação da qualidade; análise e síntese de dados; interpretação; apresentação dos resultados; e atualização da revisão. Considerando a primeira etapa, a aplicação desse método é realizada de forma a alcançar o objetivo secundário e assim identificar ferramentas que tenham como principal objetivo mitigar o problema de gerenciamento de doações e/ou perda e convergência de materiais diretamente.

$\mathrm{Na}$ etapa de busca na literatura são definidos sete procedimentos: seleção da base eletrônica de dados, identificação das palavras-chave para a pesquisa, revisão dos resumos dos artigos selecionados, aplicação de critérios para inclusão ou exclusão de artigos, revisão do texto completo dos artigos selecionados, pesquisa para trás e pesquisa para frente em documentos recuperados (método snowball).

a. Seleção da base eletrônica de dados: Scopus é a base de base de dados definida para aplicação da pesquisa por ter uma proporção maior de periódicos exclusivos em todos os campos de estudos (Mongeon e Paul-Hus, 2016). 
b. Identificação das palavras-chave para a pesquisa: são definidos três grupos de palavras-chave para a busca ser ampla o suficiente para evitar limitações na quantidade de trabalhos, sendo aplicadas nos campos do título, resumo e palavras-chave dos artigos. As palavras-chave do primeiro grupo são "humanitarian logistics" or "relief" or "disaster" para delimitar a área de pesquisa, as do segundo grupo são "system" or "program" or "software" or "tool", a fim de especificar o objeto de interesse, e as do terceiro grupo são "donation" or "donate" or "material convergency" or "material waste" or "acquisition needs" or "procurement" or "purchasing, visando a especificação do foco de interesse. A busca foi aplicada nos campos título, resumo e palavras-chave, no dia 30 de junho de 2018 resultando em 457 artigos.

c. Revisão dos resumos dos artigos selecionados e aplicação de critérios para exclusão de artigos: Alguns critérios de exclusão foram utilizados a fim de delimitar a seleção. O primeiro critério utilizado foi a linguagem, somente artigos de língua inglesa foram selecionados concomitantemente a este critério foram excluídos artigos da área médica, por se tratar prioritariamente de questões relacionadas à saúde, que foge ao escopo da pesquisa. Com estes critérios chegou-se a 307 artigos. A seguir foi feita a leitura dos resumos de todos os artigos para avaliar se estariam dentro do escopo da pesquisa de interesse, foram excluídos resumos que citavam o gerenciamento de doações / convergência de materiais apenas como uma questão subsequentemente afetada pelos resultados finais dos documentos. Nesta etapa chegou-se a 40 artigos.

d. Revisão do texto completo dos artigos selecionados: A etapa seguinte consistiu na leitura completa dos artigos selecionados e identificação de artigos que apresentassem como contribuição ferramentas ou sistemas para resolução dos problemas de gerenciamento, chegando a um total de 9 artigos com 9 ferramentas.

e. Método snowball: A etapa seguinte refere-se ao método snowball, que consiste na verificação de trabalhos citados pelos autores e outras obras citando estes documentos. Foram inclusos 2 artigos, com uma ferramenta cada. Chegando a um total de 11 ferramentas.

$\mathrm{Na}$ etapa da coleta de dados foram identificadas as ferramentas propostas nos artigos selecionados. Assegurou-se a avaliação da qualidade pela seleção e uso de artigos revisados por pares indexados na base Scopus. A etapa de análise 
de dados foi feita por meio da análise de conteúdo e para a síntese foi baseada em critérios de funcionalidades de sistemas presentes na literatura a fim de comparar as diferentes ferramentas com a mesma métrica. Já na etapa de interpretação dos dados foram analisados os padrões observados a partir dos critérios definidos. Em Tomé et al. (2016) a etapa posterior é a apresentação dos resultados, contudo o período entre a finalização desta pesquisa e a revisão sistemática realizada foi considerável, o que levou a uma defasagem de resultados. Portanto optou-se por realizar a atualização da revisão e apresentar os resultados. A busca foi realizada na mesma base de dados no dia 10 de abril de 2019. Os resultados da RSL e sua atualização podem ser observados no Quadro 2, bem como a diferença na quantidade de artigos em cada uma das etapas. Com isso, os resultados são apresentados no capítulo 4.

Quadro 2 - Comparação entre os resultados da RSL e sua atualização

\begin{tabular}{|l|c|c|c|}
\hline & RSL & Atualização da RSL & Diferença \\
\hline Busca por keywords na base de dados & 457 & 478 & 21 \\
\hline Critérios de exclusão & 307 & 324 & 17 \\
\hline Leitura de resumo & 40 & 51 & 11 \\
\hline Artigos completos com ferramentas & 9 & 12 & 3 \\
\hline Método Snowball & 2 & 5 & 3 \\
\hline Total de ferramentas & 11 & 17 & 6 \\
\hline
\end{tabular}

\subsection{Estudo de caso}

Outro método de pesquisa utilizado é o estudo de caso, definido por Cauchick et al. (2011) como um trabalho de caráter empírico que investiga um dado fenômeno dentro de um contexto real contemporâneo por meio de análise aprofundada de um ou mais objetos de análise. Yin (2017) afirma que uma das condições para utilizar o método é quanto à forma de questão de pesquisa proposta, sendo "como" e "por que" tipos justificáveis para a escolha. O estudo de caso pode ser único, que aborda apenas um caso, porém com menor possibilidade de aprofundamento. Ou pode ser múltiplo, que aborda dois ou mais casos, podendo gerar generalizações mais consistentes. Neste trabalho o método de estudo de caso múltiplo será aplicado a fim de prover maior quantidade de informações e possibilidade de generalizações.

As seis etapas definidas por Yin (2017) são a base para a aplicação do método. Segundo ele, a realização da pesquisa de estudo de caso é um processo linear, porém iterativo, conforme ilustrado na Figura 3. 


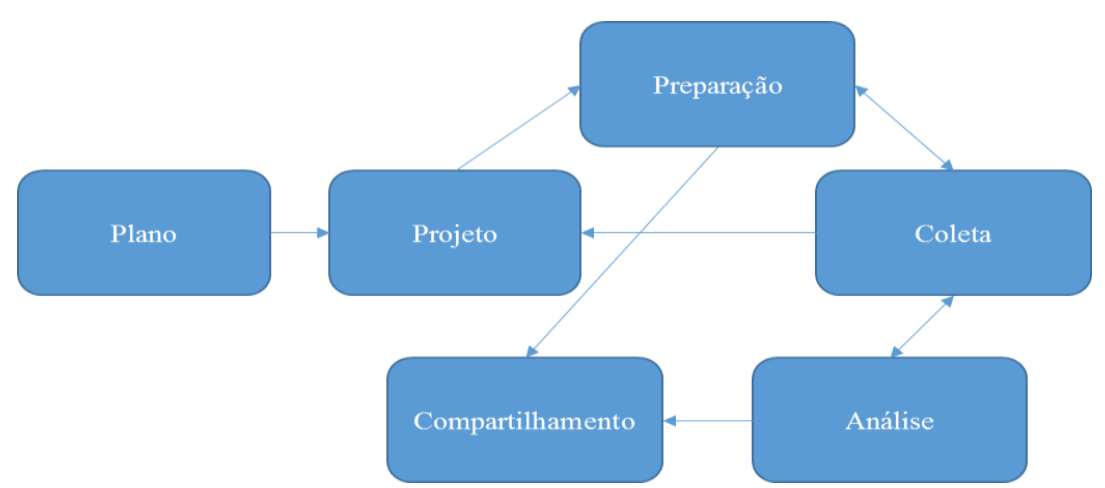

Figura 3 - Etapas do estudo de caso

Fonte: Yin (2017)

a) Plano: refere-se ao ajuste do método ao objetivo da pesquisa. Por se tratar de uma pesquisa de caráter empírico que tem por objetivo avaliar um fenômeno real e contemporâneo com diferentes fontes de evidência a escolha do método é justificável e adequada para avaliar a aceitabilidade prática do software pela perspectiva das instituições.

b) Projeto: esta etapa auxilia a elaboração do plano, tendo cinco elementos (questões de pesquisa; proposições, caso haja; unidade (s) de análise; lógica que une os dados às proposições; e critérios para interpretar as constatações). As questões de pesquisa referem-se à aceitabilidade de um software, identificando características que justifiquem a implementação do mesmo nas unidades de análise, bem como possíveis barreiras, e facilitadores de uso. Tem-se a proposição de que organizações cujas doações predominantes sejam financeiras tem menor problemas com convergência de materiais e melhor gerenciamento de suprimentos (Harvey e Bailey, 2011). No que tange as unidades de análises, por ser um estudo de múltiplos casos, são selecionadas cinco instituições que prestem assistência humanitária, localizadas no estado do Rio de Janeiro. A lógica que conecta os dados com a proposição é a lógica de correspondência de padrões e os critérios para interpretação referem-se a dados reais que possibilitem gerar pontos de discussão levando em consideração a literatura e observações do mundo real.

c) Preparação: etapa referente à elaboração de um protocolo de pesquisa, no qual se apresenta a fundamentação teórica do estudo de caso e os procedimentos para aplicar o instrumento de pesquisa, a 
fim de direcionar a coleta de dados e análise. O protocolo do presente estudo é apresentado no Apêndice 1.

d) Coleta de dados: A coleta de dados é feita ao longo do período de um mês nas instituições através de entrevistas, gravações e transcrições. É feita de maneira concomitante à apresentação técnica do sistema. São utilizados três instrumentos de coleta de dados: entrevistas semiestruturadas, a fim de compreender os processos das instituições e como se alinham à proposta do sistema; documentos e informações divulgadas pelas próprias instituições em seus sites oficias; roteiro de teste de usabilidade com as tarefas de execução definidas, a fim de uniformizar as análises e; por fim questionário padronizado, para avaliar a usabilidade do sistema pelas organizações. A coleta de dados foi realizada entre os dias 18 de dezembro de 2018 e 22 de janeiro de 2019. Os instrumentos detalhados no Apêndice 1 são usados como base para o roteiro das entrevistas, um celular com função de gravação de voz foi utilizado com a permissão de todas as instituições envolvidas. Para o teste de usabilidade foi utilizada uma versão betado sistema proposto instalado em um computador portátil e um software de captura de tela para análise em conjunto. As entrevistas duraram em média 45 minutos, enquanto os testes de usabilidade duraram em média de 35 minutos.

\section{e) Análise de dados:}

Os dados provenientes das entrevistas semiestruturadas das organizações são analisados a partir da perspectiva intracaso, a fim de realizar uma análise qualitativa sobre o contexto no qual as organizações estão inseridas e sobre a aceitabilidade do software por parte delas. É realizada ainda a triangulação dos dados através de documentos disponibilizados pelas próprias instituições em seus sites oficiais, a fim de obter informações adicionais, contrapor ou corroborar com as apresentadas durante as entrevistas.

A análise de usabilidade é feita pela perspectiva do aplicador do teste e do próprio usuário. Pela perspectiva do aplicador do teste é feito o diagnóstico sobre a execução das tarefas, que podem ser classificadas em: concluída com sucesso; concluída com dificuldade ou desistência, concomitantemente ao ranqueamento feita através da Matriz GUT, que estabelece uma ordem de prioridade em relação aos problemas encontrados levando em conta sua gravidade, urgência e tendência. $O$ critério da gravidade considera os efeitos a longo prazo e 
os impactos nas pessoas, coisas e resultados, se o problema não for resolvido. Urgência lida com o quão urgente é sua eliminação, enquanto a tendência avalia se é possível que o problema aumente progressivamente, diminua ou desapareça por si mesmo. Todos eles podem ser classificados de 1 a 5 e a avaliação final é obtida multiplicando-se as três taxas de critério (Periard, 2011). Dessa forma, é possível perceber as tarefas mais complexas e a prioridade de resolução das ocorrências. Para a análise de dados provenientes do SUMI, é utilizado o SUMISCO, software projetado exclusivamente para a avaliação do SUMI. Por se tratar de um trabalho de pesquisa, sua utilização foi gratuita. Os relatórios e cálculos, do $x^{2}$ inclusive, são fornecidos pelo próprio software, só sendo necessária a realização da análise crítica com base nos mesmos.

f) Compartilhamento: Esta etapa consiste no compartilhamento de informações sobre a pesquisa e será feita através do texto completo da presente pesquisa.

\subsection{Survey}

O método de pesquisa do tipo survey é descrito por Forza (2002) como a coleta de informações de indivíduos sobre si e sobre as unidades sociais às quais pertencem, contribuindo para o avanço do conhecimento científico em diferentes formas. O presente estudo traz uma abordagem descritiva a fim de levantar opiniões, atitudes e crenças de uma população, e identificar os fatores relacionados à doação. Quanto aos meios, utilizou-se a pesquisa survey no intuito de coletar os dados necessários para conjuntamente investigar a contribuição da interface proposta e sua influência no comportamento das pessoas. A pesquisa se orientou pela abordagem quantitativa que, segundo Denzin e Lincon (2006), proporciona estudos que enfatizam o ato de medir e analisar as relações causais entre as variáveis pesquisadas. A aplicação do método segue, de maneira resumida, as etapas definidas por Forza (2002), conforme ilustra a Figura 4.
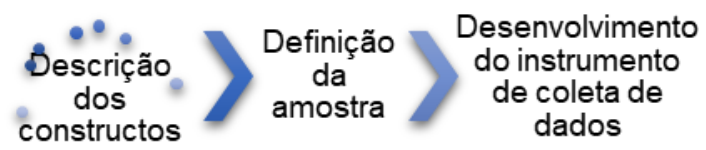
Kerlinger (1966) define constructo como um conceito adotado intencionalmente com um propósito científico definido, sendo observável e referível. Representam o passo inicial em direção à formulação de uma teoria. $\mathrm{A}$ descrição dos constructos é importante para direcionamento do instrumento, sendo a primeira etapa do método, e teve como base o levantamento na literatura sobre doações, que leva em consideração discussões feitas por alguns autores acerca do comportamento do doador, esses constructos são apresentados no Quadro 3.

A etapa seguinte de definição da amostra da pesquisa foi definida pelo método de amostragem não-probabilística, a partir do agrupamento das técnicas por conveniência, na qual os participantes são escolhidos por estarem disponíveis e snowball, na qual os participantes iniciais indicam novos participantes (Bickman e Rog, 1998).

A etapa de desenvolvimento do instrumento de coleta de dados baseia-se na revisão da literatura pertinente ao fenômeno do comportamento do doador, e pode ser verificado no Apêndice 2. O modo de coleta utilizado é o questionário eletrônico, através da plataforma OnlinePesquisa.com, por possuir licença gratuita para estudantes e pesquisadores e ter funcionalidades como ramificação de respostas e indexação de vídeos, necessárias nesta pesquisa.

Quadro 3 - Fatores identificados na Survey

\begin{tabular}{|c|c|c|c|}
\hline $\begin{array}{c}\text { Fator } \\
\text { (Constructo) }\end{array}$ & Descrição & Referência & Itens \\
\hline $\begin{array}{c}\text { Influência dos tipos } \\
\text { de desastre }\end{array}$ & $\begin{array}{c}\text { Este fator analisa se há } \\
\text { maior propensão de } \\
\text { doações para diferentes } \\
\text { tipos de desastres }\end{array}$ & Zagefka et al. (2011) & $\begin{array}{c}\text { Intrumento 4B e } \\
\text { Instrumento 4D }\end{array}$ \\
\hline Motivação & $\begin{array}{c}\text { Analisa os fatores que } \\
\text { influenciam na decisão } \\
\text { ou não de doar }\end{array}$ & $\begin{array}{c}\text { Certo (2003); IDIS, } \\
\text { 2015; da Costa, } \\
\text { Daré e Veloso } \\
(2012)\end{array}$ & $\begin{array}{c}\text { Instrumento 4B; } \\
\text { Instrumento 4C; } \\
\text { Instrumento 4D e } \\
\text { Instrumento 4E (1;2;7;9) }\end{array}$ \\
\hline Preferências & $\begin{array}{c}\text { Analisa as predileções } \\
\text { no ato de doar }\end{array}$ & $\begin{array}{c}\text { Certo (2003); IDIS, } \\
2015 ; \text { da Costa, } \\
\text { Daré e Veloso } \\
(2012)\end{array}$ & $\begin{array}{c}\text { Instrumento 4E } \\
(3 ; 4 ; 5 ; 6 ; 7)\end{array}$ \\
\hline
\end{tabular}

Após a elaboração do instrumento de pesquisa, é preciso realizar um teste piloto para verificar se os mesmos são compreensíveis, mensurar tempo de resposta média, a fim de aprimorar o planejamento da coleta de dados e procedimentos metodológicos. Pela maior praticidade é feito o pré-teste cognitivo, no qual a entrevistadora pergunta para o entrevistado qual a sua compreensão de cada questão apresentada. Diante da sua resposta é possível obter sua real 
percepção do questionário, a partir da possibilidade que o entrevistado pode fazer sua própria avaliação de termos e expressões da pesquisa. Assim é possível evitar respostas destoantes, ou influenciadas pelos próprios aplicadores, prevenindo resultados não eficazes (Instituto Opus, 2018). O pré-teste é feito com dois estudantes de mestrado do departamento de Engenharia Industrial da PUC-Rio no dia 29 de novembro de 2018.

A coleta de dados foi realizada entre os dias 21 de dezembro de 2018 a 30 de janeiro de 2019 em caráter transversal, ou seja, uma única vez ao longo do tempo. O questionário que pode ser consultado no Apêndice 2 foi respondido por 107 pessoas, porém nem todos o responderam de maneira integral. Ao longo das análises a quantidade de respondentes da pergunta em questão é explicitado. Os dados incompletos podem ser classificados como não respostas parciais, que é o termo utilizado entre não respostas totais e de item, ocorrem quando um participante corta a entrevista no meio, quando um respondente em uma pesquisa de painel não fornece dados para um ou mais grupos do painel, ou quando um respondente em uma pesquisa multifásica fornece dados para algumas, mas não todas as fases de coleta de dados. A abordagem para lidar com esses dados pode ser por ponderação ou imputação (Brick e Kalton,1996). Com a abordagem de ponderação, os não-participantes parciais são eliminados do arquivo de análise, envolvendo o descarte das respostas que os não-respondentes parciais forneceram. Já na abordagem por imputação, os não-participantes parciais são retidos no arquivo de análise e a imputação é usada para preencher todas as respostas ausentes. No entanto, é extremamente difícil manter as associações entre todas as variáveis da pesquisa, logo optou-se pelo descarte das não respostas e somente serão consideradas as respostas daqueles que responderam de maneira integral.

Os dados da amostra são analisados por meio de técnicas de estatística descritiva. A organização dos resultados é feita em uma planilha, a fim de possibilitar a análise das principais perguntas; tabulação cruzada de resultados; e cálculos estatísticos para avaliar a aceitabilidade do sistema pelos usuários, além de prover para as instituições insights sobre o comportamento do doador e oferecer facilidade de manipulação e acesso para a pesquisa. A partir da análise dos dados esperasse ser possível a explanação dos fatores descritos e ser capaz de avaliar a aceitabilidade social do sistema, além de proposições de melhorias para o mesmo. 


\section{4}

\section{Análise das funcionalidades do SmartDonation}

O desenvolvimento de ferramentas em LH cresceu consideravelmente principalmente em áreas de execução logística, contudo o desenvolvimento de sistemas ainda possui uma ampla margem de atuação, conforme demonstra o resultado da RSL. O Quadro 4 mostra um resumo sobre cada uma das 17 ferramentas encontradas. Maiores detalhes são dados em Mendes et al. (2019a). As ferramentas foram classificadas a partir de 26 funcionalidades e características, sendo as 19 primeiras, funcionalidades baseadas nos estudos de Blecken (2009); Careem et al. (2006); Shafiq et al. (2012) e Eckhardt e Leiras (2015), enquanto as demais características baseiam-se nos estudos de Poblet, García-Cuesta e Casanovas (2013); Bacigalupe e Velasco-Martin (2018). Essas informações e maiores detalhamentos podem ser vistos no Apêndice 3. 
Quadro 4 - Resumo das ferramentas encontradas

\begin{tabular}{|c|c|c|c|}
\hline & Instituição & Descrição da ferramenta & Fonte \\
\hline Donate.Ik & $\begin{array}{l}\text { Sri Lanka Institute } \\
\text { of Information } \\
\text { Tecchnology }\end{array}$ & $\begin{array}{l}\text { Oferece a combinação de recursos como gerenciamento de doações, apoio de equipes de doações e fornecimento de } \\
\text { voluntários e equipes para alcançar as pessoas necessitadas de maneira ideal e segura. Usa uma base de dados } \\
\text { histórica sobre o clima a fim de encontrar padrões através da mineração de dados. }\end{array}$ & $\begin{array}{l}\text { Lanerolle et al. } \\
\qquad(2018)\end{array}$ \\
\hline Sahana & $\begin{array}{c}\text { Free Open } \\
\text { Source Software }\end{array}$ & $\begin{array}{l}\text { Possui composição modular com as seguintes funcionalidades: auxí́lio para hospitais, instalações médicas e vínculo } \\
\text { de registros de vítimas a relatórios de pessoas desaparecidas; gestão de pessoas; registro de organizações, } \\
\text { acompanhemanto de projetos, gerenciamento de voluntários, gerenciamento de estoques, projeção de cenários, } \\
\text { mapeamento de locais e gestão de abrigos }\end{array}$ & $\begin{array}{c}\text { Ortuño et al., } \\
2013\end{array}$ \\
\hline DAISM & $\begin{array}{c}\text { Petra Christian } \\
\text { University }\end{array}$ & $\begin{array}{l}\text { Sistema integrado de informações rápidas e confiáveis ao doador sobre as necessidades dos destinatários, o sistema } \\
\text { de financiamento e o fornecimento de setores empresariais. O sistema considera algumas decisões, como localização } \\
\text { de instalação, proposição de estoque, alocação de recursos e distribuição de itens, além do envolvimento de } \\
\text { fornecedores de suprimentos para simplificar e acelerar o sistema de distribuição para o local do desastre. }\end{array}$ & $\begin{array}{c}\text { Setiabudi et al. } \\
\quad(2018)\end{array}$ \\
\hline QRH & $\begin{array}{l}\text { University of } \\
\text { California }\end{array}$ & $\begin{array}{l}\text { Sistema que permite aos voluntários hospedar rapidamente seus próprios sistemas de resposta a desastres e ajudar } \\
\text { os que estão por perto sem ter amplo conhecimento técnico. A interface do sistema é projetada para garantir que a } \\
\text { tarefa de criar uma estação de resposta seja tão simples quanto baixar um programa executável. }\end{array}$ & $\begin{array}{l}\text { Agrawal, } \\
\text { Springer e } \\
\text { Lovell, } 2015\end{array}$ \\
\hline GGDC * & $\begin{array}{l}\text { CIDI / University } \\
\text { of Rhode Island / } \\
\text { DePaul University }\end{array}$ & $\begin{array}{l}\text { Ferramenta educativa semelhante a um jogo que informa os usuários sobre algumas das complexidades associadas } \\
\text { às cadeias de suprimentos humanitários e a natureza ineficaz de doações não solicitadas físicas comparadas a } \\
\text { contribuições monetárias quando enviadas em resposta a um desastre internacional. }\end{array}$ & $\begin{array}{c}\text { Özpolat et al., } \\
2015)\end{array}$ \\
\hline A2I & $\begin{array}{l}\text { Universidade } \\
\text { Federal do Rio de } \\
\quad \text { Janeiro }\end{array}$ & $\begin{array}{l}\text { Sistema para suportar a integração da informação. A abordagem utiliza representação gráfica e princípios de Linked } \\
\text { Open Data (LOD) como estratégia de adaptação de estrutura e descrição de dados. A arquitetura utiliza informações } \\
\text { disponíveis mundialmente na Web para atender às demandas inesperadas de informações complementares. Com } \\
\text { esses recursos, é possível fornecer uma visão integrada de acordo com a função do usuário. }\end{array}$ & $\begin{array}{c}\text { De Faria et al. } \\
(2014)\end{array}$ \\
\hline Relpio & $\begin{array}{l}\text { UFRJ / FAETEC / } \\
\text { Universidade } \\
\text { Severino Sombra }\end{array}$ & $\begin{array}{l}\text { Mecanismo de cadastro para vítima a fim de solicitar ajuda aos órgãos responsáveis e ainda apresentar os principais } \\
\text { pontos de apoio para recebimento de doações, de forma que pessoas interessadas em ajudar essas vítimas possam } \\
\text { encontrar locais adequados para realização de doações. }\end{array}$ & $\begin{array}{l}\text { Pereira et al. } \\
\quad(2016)\end{array}$ \\
\hline (SMERC) & $\begin{array}{c}\text { George Mason } \\
\text { University }\end{array}$ & $\begin{array}{l}\text { Identifica e combina automaticamente solicitações e ofertas de recursos incluindo abrigos, dinheiro, trabalho voluntário, } \\
\text { roupas e suprimentos médicos através de mídias sociais. A correspondência efetiva dessas mensagens pode ajudar a } \\
\text { criar resiliência e permitir que as comunidades recuperem mais rapidamente após um desastre }\end{array}$ & $\begin{array}{l}\text { Purohit et al. } \\
\quad(2014)\end{array}$ \\
\hline
\end{tabular}

Continua 


\section{Quadro 4 - Final}

\begin{tabular}{|c|c|c|c|}
\hline AidMatrix & $\begin{array}{c}\text { Federal } \\
\text { Emergency } \\
\text { Management } \\
\text { Agency (FEMA) }\end{array}$ & $\begin{array}{l}\text { Rede virtual otimizada capaz de conectar governos, doadores e organizações humanitárias, buscando articular oferta } \\
\text { e demanda (AidMatrix, 2018). As principais frentes de atuação são gerenciamento de doações, tanto financeira como } \\
\text { material, e gestão de voluntários. Uma das funcionalidades da plataforma é a integração entre entidades humanitárias } \\
\text { otimizando seus esforços e alcançando uma melhor gestão, seja na aquisição ou entrega. }\end{array}$ & AidMatrix, 2018 \\
\hline HELIOS & Fritz Institute & $\begin{array}{l}\text { O sistema fornece visibilidade completa em toda a cadeia de suprimentos humanitária, desde a mobilização até o } \\
\text { depósito. Ele automatiza os processos de logística nos níveis estratégico e operacional e fornece visibilidade de cada } \\
\text { uma dessas perspectivas }\end{array}$ & $\begin{array}{l}\text { Fritz Institute, } \\
\quad 2018\end{array}$ \\
\hline Helping Hand & UITS Dhaka & $\begin{array}{l}\text { Aplicação móvel intitulada Helping Hand, que visa ser uma plataforma eficaz e mais fácil de doar dinheiro através de } \\
\text { serviços bancários móveis. A aplicação proposta busca garantir a transparência do processo de doação. Tendo ainda } \\
\text { como uma das funções a possibilidade de as pessoas afetadas procurarem ajuda para si ou para outras pessoas } \\
\text { através desta aplicação. Sendo uma plataforma onde as pessoas possam ajudar umas às outras em poucos minutos. }\end{array}$ & $\begin{array}{l}\text { Ahmed, Yasmin } \\
\text { e Imtiaz (2014) }\end{array}$ \\
\hline RDP & $\begin{array}{l}\text { UC Irvine / City of } \\
\text { Ontario Fire } \\
\text { Department }\end{array}$ & $\begin{array}{l}\text { Portal de informações multifacetado para uso por cidadãos e agências de emergência durante desastres e resposta a } \\
\text { emergências. O portal fornece uma ampla gama de informações em tempo real em situações de desastre, como } \\
\text { resumos de situação, anúncios, informações sobre abrigos e serviços agregados, como reagrupamento familiar e } \\
\text { gerenciamento de doações }\end{array}$ & $\begin{array}{l}\text { Lickfett et al. } \\
\text { (2008) }\end{array}$ \\
\hline UICDS & $\begin{array}{l}\text { Rutgers University } \\
\text { College of Staten } \\
\text { Island-City UNY } \\
\end{array}$ & $\begin{array}{l}\text { Sistema capaz de promover o compartilhamento de informações e conscientização em situações de emergência, capaz } \\
\text { de dar visibilidade de recursos, compartilhamento de informações e interoperabilidade entre diferentes sistemas de } \\
\text { agências. }\end{array}$ & $\begin{array}{c}\text { Shafiq et al. } \\
(2012)\end{array}$ \\
\hline Dlogis & $\begin{array}{l}\text { Sebelas Maret } \\
\text { University }\end{array}$ & $\begin{array}{l}\text { É direcionado tanto para uso da população, quanto do governo, que podem usá-lo diretamente quando há um desastre. } \\
\text { Existem cinco menus principais. O primeiro mostra informações sobre desastres, condições dos atingidos etc..O } \\
\text { segundo é usado para inserir dados de sobreviventes. O terceiro é usado para informações logísticas. O quarto exibe } \\
\text { o estoque disponível para o coordenador de campo. E o último menu exibe a ajuda já aceita e enviada por doação. }\end{array}$ & $\begin{array}{l}\text { (Koesuma et al., } \\
\text { 2017) }\end{array}$ \\
\hline HandsOn & PUC-Rio (Hands) & $\begin{array}{l}\text { Ferramenta de apoio a operações de desastres no qual é possível realizar o cadastro do desastre com suas respectivas } \\
\text { características, verificar a disponibilidade de recursos humanos e insumos e as organizações governamentais que são } \\
\text { capazes de gerenciar essas informações e tomar decisões. }\end{array}$ & $\begin{array}{l}\text { Silva e Leiras } \\
\quad(2015)\end{array}$ \\
\hline SUMA & $\begin{array}{l}\text { Organização Pan- } \\
\text { Americana de } \\
\text { Saúde }\end{array}$ & $\begin{array}{l}\text { Composto por três módulos: SUMA Central; Unidade de campo; Gestão de estoque. O funcionamento é dado da } \\
\text { seguinte maneira: a Central define os parâmetros estratégicos, a fim de que os suprimentos sejam adequadamente } \\
\text { gerenciados, então a Unidade de campo classifica e rotula os suprimentos recebidospor nível de prioridade. }\end{array}$ & $\begin{array}{l}\text { Ortuño et al., } \\
2013\end{array}$ \\
\hline DONARE & $\begin{array}{l}\text { Defesa Civil de } \\
\text { Capinas }\end{array}$ & $\begin{array}{l}\text { Sistema desenvolvido para uso da Defesa Civil de Campinas, visando o gerenciamento de donativos interface focada } \\
\text { na diminuição dos esforços de treinamento de usuário; base de dados, onde serão cadastradas informações sobre } \\
\text { possíveis voluntários, transportadoras, abrigos, famílias beneficiadas e armazéns, além de fazer o controle da } \\
\text { movimentação dos donativos; geração de relatórios de informações objetivas }\end{array}$ & $\begin{array}{l}\text { Sidrão et al., } \\
\quad 2011\end{array}$ \\
\hline
\end{tabular}


Tabela 1 - Funcionalidades e características das ferramentas

\begin{tabular}{|c|c|c|c|c|c|c|c|c|c|c|c|c|c|c|c|c|c|c|c|}
\hline Funcionalidade & $\begin{array}{l}\bar{\Phi} \\
\stackrel{\Phi}{\Phi} \\
\stackrel{0}{0} \\
\stackrel{0}{0}\end{array}$ & 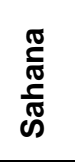 & $\frac{\sum}{\frac{\omega}{\delta}}$ & $\begin{array}{l}\frac{T}{\widetilde{r}} \\
\frac{\sigma}{\sigma}\end{array}$ & ن & হ্ণ & $\frac{\circ}{\frac{0}{0}}$ & $\begin{array}{l}\text { U్ } \\
\text { ய } \\
\underset{\underbrace{}}{\tilde{E}}\end{array}$ & $\frac{i}{\frac{\pi}{\pi}}$ & 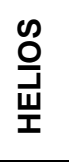 & 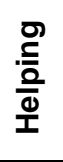 & 吕 & $\begin{array}{l}0 \\
\text { O } \\
\end{array}$ & $\begin{array}{l}\frac{n}{5} \\
\text { 음 }\end{array}$ & 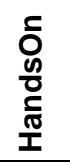 & 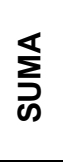 & 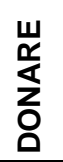 & $\begin{array}{l}\text { 早 } \\
\text { ฮั } \\
\text { ஸे }\end{array}$ & $\begin{array}{l}\overline{5} \\
\text { 음 }\end{array}$ \\
\hline (SCM) Projeto e Desenho & $\circ$ & $\circ$ & $\bullet$ & o & $\circ$ & $\circ$ & $\circ$ & $\circ$ & $\circ$ & $\bullet$ & $\circ$ & $\circ$ & $\circ$ & $\circ$ & $\bullet$ & ○ & $\circ$ & $\circ$ & 3 \\
\hline (SCM) Planejamento & $\bullet$ & $\circ$ & $\bullet$ & $\circ$ & $\circ$ & $\bullet$ & $\circ$ & $\circ$ & $\circ$ & $\bullet$ & $\circ$ & $\circ$ & $\bullet$ & $\circ$ & $\bullet$ & $\circ$ & $\circ$ & $\bullet$ & 7 \\
\hline (SCM) Execução & $\bullet$ & $\bullet$ & $\bullet$ & $\bullet$ & $\circ$ & $\bullet$ & $\bullet$ & $\bullet$ & $\bullet$ & $\bullet$ & $\bullet$ & $\bullet$ & $\bullet$ & $\bullet$ & $\bullet$ & $\bullet$ & $\bullet$ & $\bullet$ & 17 \\
\hline Documentação & $\bullet$ & $\bullet$ & $\bullet$ & $\circ$ & ○ & $\bullet$ & $\bullet$ & $\circ$ & $\bullet$ & $\bullet$ & $\bullet$ & $\bullet$ & $\bullet$ & $\circ$ & $\bullet$ & $\bullet$ & $\bullet$ & $\bullet$ & 14 \\
\hline Relatórios & ○ & $\bullet$ & $\bullet$ & ० & ○ & $\circ$ & $\circ$ & $\circ$ & $\bullet$ & $\bullet$ & $\circ$ & $\bullet$ & $\bullet$ & $\bullet$ & $\bullet$ & $\bullet$ & $\bullet$ & ○ & 10 \\
\hline Acessibilidade & $\bullet$ & $\circ$ & $\circ$ & $\bullet$ & ○ & $\circ$ & $\circ$ & $\circ$ & $\bullet$ & $\bullet$ & $\circ$ & ○ & $\circ$ & $\circ$ & $\bullet$ & ○ & ○ & $\bullet$ & 6 \\
\hline Controladoria & $\bullet$ & $\bullet$ & $\bullet$ & $\circ$ & ○ & $\circ$ & $\circ$ & $\circ$ & $\bullet$ & $\bullet$ & $\bullet$ & ○ & $\bullet$ & ○ & $\bullet$ & $\bullet$ & $\bullet$ & ○ & 10 \\
\hline Cross-linking & $\circ$ & $\bullet$ & $\circ$ & $\circ$ & ० & $\bullet$ & $\circ$ & $\circ$ & $\circ$ & $\bullet$ & $\circ$ & $\bullet$ & $\bullet$ & $\circ$ & $\bullet$ & ○ & $\bullet$ & $\circ$ & 7 \\
\hline Modularidade / Adaptabilidade & $\bullet$ & $\bullet$ & $\circ$ & $\bullet$ & ० & $\circ$ & $\circ$ & $\circ$ & $\bullet$ & $\bullet$ & $\circ$ & $\bullet$ & $\bullet$ & $\circ$ & $\bullet$ & $\bullet$ & $\bullet$ & $\circ$ & 10 \\
\hline Usabilidade & $\bullet$ & $\bullet$ & $\circ$ & $\bullet$ & $\bullet$ & $\circ$ & $\bullet$ & $\circ$ & $\circ$ & $\bullet$ & $\bullet$ & $\bullet$ & $\bullet$ & $\bullet$ & $\bullet$ & $\bullet$ & $\bullet$ & $\bullet$ & 14 \\
\hline Custos Diretos & $\bullet$ & $\bullet$ & $\bullet$ & $\bullet$ & ० & $\circ$ & $\circ$ & $\circ$ & $\bullet$ & $\bullet$ & $\circ$ & $\bullet$ & $\bullet$ & $\bullet$ & $\bullet$ & $\bullet$ & $\bullet$ & $\bullet$ & 13 \\
\hline Custos Indiretos & $\bullet$ & $\bullet$ & $\bullet$ & $\bullet$ & ○ & $\circ$ & $\circ$ & $\circ$ & $\bullet$ & $\bullet$ & $\circ$ & $\bullet$ & $\bullet$ & $\bullet$ & $\bullet$ & $\bullet$ & $\bullet$ & $\bullet$ & 13 \\
\hline Registro de Voluntários & $\bullet$ & $\bullet$ & $\bullet$ & $\bullet$ & ० & $\circ$ & $\circ$ & $\circ$ & $\bullet$ & $\circ$ & $\circ$ & ○ & $\bullet$ & $\circ$ & $\bullet$ & ○ & $\bullet$ & $\bullet$ & 9 \\
\hline Notificações & $\circ$ & $\bullet$ & $\circ$ & $\circ$ & ० & $\circ$ & $\circ$ & $\circ$ & $\circ$ & $\circ$ & $\circ$ & $\bullet$ & $\bullet$ & $\bullet$ & $\bullet$ & ○ & ○ & $\bullet$ & 6 \\
\hline Interoperabilidade & $\circ$ & $\bullet$ & $\circ$ & $\bullet$ & ० & $\bullet$ & $\circ$ & $\circ$ & $\bullet$ & $\circ$ & $\circ$ & $\bullet$ & $\bullet$ & ○ & $\bullet$ & ○ & ○ & ○ & 7 \\
\hline Segurança da Informação & $\bullet$ & $\bullet$ & $\bullet$ & $\bullet$ & $\circ$ & $\bullet$ & ○ & $\circ$ & ○ & $\bullet$ & & $\bullet$ & $\bullet$ & $\bullet$ & $\bullet$ & ○ & $\bullet$ & $\bullet$ & 12 \\
\hline Multiusuários & $\bullet$ & $\circ$ & $\circ$ & $\circ$ & $\circ$ & $\bullet$ & $\bullet$ & $\circ$ & $\circ$ & $\circ$ & $\bullet$ & $\bullet$ & $\bullet$ & $\circ$ & $\bullet$ & $\circ$ & $\circ$ & $\bullet$ & 8 \\
\hline Avaliação de doadores & $\bullet$ & $\circ$ & $\circ$ & $\circ$ & $\circ$ & $\circ$ & $\circ$ & $\circ$ & $\circ$ & $\circ$ & $\circ$ & ○ & $\circ$ & $\circ$ & $\bullet$ & $\circ$ & $\circ$ & $\circ$ & 2 \\
\hline Base de Dados Histórica & $\bullet$ & $\bullet$ & $\bullet$ & $\bullet$ & $\circ$ & $\circ$ & $\bullet$ & $\bullet$ & $\circ$ & $\bullet$ & $\circ$ & $\bullet$ & $\bullet$ & $\bullet$ & $\bullet$ & $\bullet$ & $\circ$ & $\bullet$ & 13 \\
\hline Total & 14 & 14 & 11 & 10 & 1 & 7 & 5 & 2 & 10 & 14 & 5 & 13 & 16 & 8 & 19 & 9 & 10 & 12 & \\
\hline
\end{tabular}


A Tabela 1 resume as funcionalidades descritas por Eckhardt e Leiras (2015) identificadas nas ferramentas, enquanto a Tabela 2 fornece algumas características adicionais. O símbolo $(\bullet)$ mostra que a ferramenta possui a funcionalidade/característica em questão e, caso contrário, o símbolo utilizado é (०). Além das 17 ferramentas encontradas, é incluso para fins comparativos o objeto de estudo SmartDonation. No que tange as funcionalidades apresentadas na Tabela 1, as ferramentas que possuem maior quantidade delas são o HandsOn e o UICDS, com 19 e 16 funcionalidades respectivamente. Em contrapartida, duas das ferramentas analisadas possuem pouquíssimas funcionalidades, como é o caso do GGDC e SMERC, com uma e duas funcionalidades respectivamente. Esse baixo número de funções apresentadas é justificado pelo propósito de ambos. O primeiro é uma ferramenta educativa que visa instruir potenciais doadores acerca dos impactos das doações materiais, e apesar de não compreender todas as funcionalidades pode impactar significativamente o problema de convergência de materiais amplamente citado por Holguín-Veras et al. (2012). Já o SMERC é uma aplicação de NPL e machine learning em mídias sociais a fim de encontrar recursos apropriados para beneficiários que também colabora para a minimização da convergência de materiais. Por não serem de natureza gerencial, suas funcionalidades apresentam-se de maneira relativamente simples, mas que não apequenam seu alcance e impacto nos problemas citados.

Vale ressaltar ainda que as funcionalidades Supply Chain Management Execução; Acessibilidade; Usabilidade e Segurança de Informação são consideradas no estudo de Eckhardt e Leiras (2015) como as mais importantes dentre as demais. SCM Execução aparece em 17 das 18 ferramentas analisadas, demonstrando o foco na fase operacional, enquanto a Usabilidade está presente em 14 das ferramentas, e Segurança da informação em 12, indicando uma preocupação com a satisfação do usuário final e boas práticas do mercado, conforme Blecken (2009) e Eckhardt e Leiras (2015), salientam em seus estudos. Esse alto número de ferramentas com tais funcionalidades, indica que elas são amplamente consideradas no desenvolvimento de softwares em LH. Entretanto, a funcionalidade Acessibilidade, referente a capacidade de a ferramenta ser acessível local e remotamente, apresenta-se em apenas 6 ferramentas, o que demonstra uma lacuna ainda existente nas soluções desenvolvidas. Como destacado por Howden (2009) o suporte a decisões de longo prazo gera o aumento da capacidade de resiliência das unidades logísticas e comunidades, uma importante funcionalidade associada a isto é SCM (projeto e desenho), que 
estão presentes em um pequeno número de ferramentas, sinalizando outra lacuna no desenvolvimento dos sistemas, preocupados quase que unicamente com a fase operacional. Além dessa função, a avaliação de doadores é subutilizada, esta que compreende a análise do cumprimento dos compromissos acordados, que pode ser uma boa ferramenta para projeção do fluxo de caixa das organizações.

Um aspecto interessante que pode ser observado é o destaque de duas funcionalidades, a de documentação e base histórica de dados, que são encontradas em um grande número de ferramentas (14 e 13, nesta ordem), demonstrando considerável preocupação por parte dos desenvolvedores com aspectos informativos sobre os sistemas e a viabilização do uso de dados pregressos para operações futuras, contudo esta preocupação não se reflete no compartilhamento de informações seja internamente ou externamente, aspectos relacionados com as funcionalidades Cross-linking e Interoperabilidade. Essas últimas funcionalidades citadas possuem relação direta com o desenvolvimento da gestão do conhecimento citado por Tatham e Spens (2011) como aspecto chave na revolução da cadeia de suprimentos comercial, ainda longe de ser alcançada pela LH. Obviamente os aspectos das operações humanitárias são muito mais desafiadores, entretanto caso essas funcionalidades não sejam aprimoradas e constantemente perseguidas as melhorias para o campo serão mais lentas e pouco colaborativas.

O objeto do presente estudo (SmartDonation), apresenta 12 das 19 funcionalidades analisadas, apresentando as quatro funcionalidades consideradas principais por Eckhardt e Leiras (2015). Dos 18 sistemas analisados, 6 possuem um número maior de funcionalidades que o SmartDonation, a saber: Donate.IK; Sahana; Helios; Rescue Disaster Portal; UICDS e o HandsOn. Porém apenas 3 apresentam as 4 funcionalidades principais (Donate.IK, Helios e HandsOn).

Como dito anteriormente o quantitativo das funcionalidades não é um fator determinante para atestar a superioridade de um sistema em relação ao outro. Contudo com base nas funcionalidades apresentadas, pode-se propor ao objeto do presente estudo (SmartDonation), essencialmente caso seja apontada a necessidade de melhorias pelos stakeholders envolvidos nos próximos passos da pesquisa, que seu processo de aperfeiçoamento seja baseado nas ferramentas já existentes que possuem as funcionalidades ausentes em sua concepção, a fim de potencializar sua utilização e impacto. 
Tabela 2 - Funcionalidades e características adicionais

\begin{tabular}{|c|c|c|c|c|c|c|c|c|c|c|c|c|c|c|c|c|c|c|c|c|}
\hline & Características & 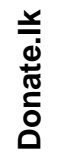 & $\begin{array}{l}\frac{\pi}{\frac{5}{\pi}} \\
\frac{5}{\pi} \\
\text { ஸे }\end{array}$ & $\frac{\sum}{\frac{0}{\Delta}}$ & $\frac{I}{\mathbb{O}}$ & $\begin{array}{l}* \\
\text { U } \\
\text { O্ }\end{array}$ & হুষ & $\frac{ㅇ}{\frac{0}{0}}$ & 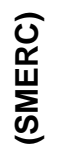 & 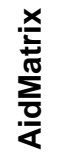 & $\begin{array}{l}\text { 음 } \\
\text { 픔 }\end{array}$ & $\begin{array}{l}\text { 옴 } \\
\text { 음 } \\
\text { 옴 }\end{array}$ & 号 & $\begin{array}{l}\text { D } \\
\text { 음 }\end{array}$ & $\begin{array}{l}\frac{n}{\delta} \\
\frac{0}{0}\end{array}$ & 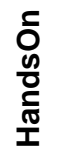 & $\varliminf_{う}^{\nwarrow}$ & 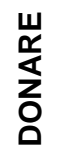 & 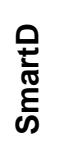 & 宓 \\
\hline \multirow{4}{*}{$\begin{array}{l}\text { Etapa do ciclo de } \\
\text { desastre }\end{array}$} & Mitigação & $\circ$ & $\bullet$ & $\bullet$ & $\circ$ & $\bullet$ & $\circ$ & ○ & $\circ$ & $\circ$ & $\bullet$ & $\circ$ & $\circ$ & $\circ$ & $\circ$ & $\bullet$ & $\circ$ & $\circ$ & $\circ$ & 5 \\
\hline & Preparação & $\bullet$ & $\bullet$ & $\bullet$ & $\circ$ & $\circ$ & $\bullet$ & ○ & $\circ$ & $\circ$ & $\bullet$ & ○ & $\circ$ & $\bullet$ & $\circ$ & $\bullet$ & $\circ$ & $\circ$ & $\bullet$ & 8 \\
\hline & Resposta & $\bullet$ & $\bullet$ & $\bullet$ & $\bullet$ & $\circ$ & $\bullet$ & $\bullet$ & $\bullet$ & $\bullet$ & $\bullet$ & $\bullet$ & $\bullet$ & $\bullet$ & $\bullet$ & $\bullet$ & $\bullet$ & $\bullet$ & $\bullet$ & 17 \\
\hline & Recuperação & $\bullet$ & $\bullet$ & $\bullet$ & $\bullet$ & $\circ$ & $\circ$ & $\circ$ & $\bullet$ & $\bullet$ & $\bullet$ & $\bullet$ & $\bullet$ & $\bullet$ & $\bullet$ & $\bullet$ & $\bullet$ & $\bullet$ & $\bullet$ & 15 \\
\hline \multirow{3}{*}{$\begin{array}{l}\text { Disponibilidade da } \\
\text { ferramenta }\end{array}$} & Opensource & $\circ$ & $\bullet$ & $\circ$ & $\bullet$ & $\circ$ & $\bullet$ & $\circ$ & $\circ$ & $\circ$ & $\bullet$ & $\circ$ & $\bullet$ & $\circ$ & $\circ$ & $\circ$ & $\circ$ & $\circ$ & $\circ$ & 5 \\
\hline & Freeware & $\circ$ & $\bullet$ & $\circ$ & $\circ$ & $\circ$ & $\circ$ & $\circ$ & $\circ$ & $\circ$ & $\bullet$ & $\circ$ & $\circ$ & $\circ$ & $\circ$ & $\circ$ & $\circ$ & $\circ$ & $\bullet$ & 3 \\
\hline & Proprietário / Comercial & $\bullet$ & $\circ$ & $\bullet$ & $\circ$ & $\bullet$ & $\circ$ & $\bullet$ & $\bullet$ & $\bullet$ & $\circ$ & $\bullet$ & $\circ$ & $\bullet$ & $\bullet$ & $\bullet$ & $\bullet$ & $\bullet$ & $\circ$ & 12 \\
\hline \multirow{3}{*}{$\begin{array}{l}\text { Nível hierárquico de } \\
\text { implementação }\end{array}$} & Conceitual & $\circ$ & $\circ$ & $\bullet$ & $\bullet$ & $\circ$ & $\circ$ & $\bullet$ & $\circ$ & $\circ$ & $\circ$ & ○ & $\circ$ & o & o & o & o & o & o & 3 \\
\hline & Operacional & $\circ$ & $\circ$ & $\circ$ & $\circ$ & $\circ$ & $\bullet$ & $\circ$ & $\bullet$ & $\circ$ & $\circ$ & $\bullet$ & $\circ$ & $\bullet$ & $\circ$ & $\circ$ & $\circ$ & $\circ$ & $\circ$ & 4 \\
\hline & Implementado & $\bullet$ & $\bullet$ & $\circ$ & $\circ$ & $\bullet$ & $\circ$ & $\circ$ & $\circ$ & $\bullet$ & $\bullet$ & $\circ$ & $\bullet$ & $\circ$ & $\bullet$ & $\bullet$ & $\bullet$ & $\bullet$ & $\bullet$ & 11 \\
\hline \multirow{3}{*}{ Aplicação (Interface) } & Mobile / App & $\bullet$ & $\circ$ & $\bullet$ & $\circ$ & $\circ$ & $\circ$ & $\bullet$ & $\circ$ & $\circ$ & $\circ$ & $\bullet$ & $\circ$ & $\circ$ & $\bullet$ & $\circ$ & $\circ$ & $\circ$ & $\bullet$ & 6 \\
\hline & Web & $\bullet$ & $\bullet$ & $\bullet$ & $\bullet$ & $\bullet$ & $\bullet$ & $\circ$ & $\bullet$ & $\bullet$ & $\bullet$ & ○ & $\bullet$ & $\bullet$ & $\bullet$ & $\bullet$ & $\circ$ & $\circ$ & $\circ$ & 13 \\
\hline & Desktop & $\circ$ & $\circ$ & $\circ$ & $\circ$ & $\circ$ & $\circ$ & $\circ$ & $\circ$ & $\circ$ & $\circ$ & $\circ$ & $\circ$ & $\circ$ & $\circ$ & $\circ$ & $\bullet$ & $\bullet$ & $\circ$ & 2 \\
\hline \multirow{4}{*}{ Desenvolvedores } & Iniciativa privada & $\circ$ & $\circ$ & $\circ$ & $\circ$ & $\circ$ & $\circ$ & $\circ$ & $\circ$ & $\circ$ & $\circ$ & $\circ$ & $\circ$ & $\circ$ & $\circ$ & $\circ$ & $\circ$ & $\circ$ & $\circ$ & 0 \\
\hline & Orgão governamental & $\circ$ & $\circ$ & $\circ$ & $\circ$ & $\bullet$ & $\circ$ & $\circ$ & $\circ$ & $\circ$ & $\circ$ & $\circ$ & $\bullet$ & $\bullet$ & $\circ$ & $\circ$ & $\bullet$ & $\bullet$ & $\circ$ & 5 \\
\hline & Instituição acadêmica & $\bullet$ & $\circ$ & $\bullet$ & $\bullet$ & $\bullet$ & & $\bullet$ & $\bullet$ & $\circ$ & $\circ$ & $\bullet$ & $\bullet$ & $\circ$ & $\bullet$ & $\bullet$ & $\circ$ & $\bullet$ & $\bullet$ & 12 \\
\hline & ONG & $\circ$ & $\bullet$ & $\circ$ & $\circ$ & $\circ$ & $\circ$ & $\circ$ & $\circ$ & $\bullet$ & $\bullet$ & $\circ$ & $\circ$ & $\circ$ & $\circ$ & $\circ$ & $\circ$ & $\circ$ & $\circ$ & 3 \\
\hline \multicolumn{2}{|c|}{ Participação popular } & $\bullet$ & $\circ$ & $\bullet$ & $\circ$ & $\circ$ & $\circ$ & $\bullet$ & $\bullet$ & $\circ$ & $\circ$ & $\bullet$ & $\bullet$ & $\circ$ & $\bullet$ & $\bullet$ & $\circ$ & $\circ$ & $\bullet$ & 9 \\
\hline \multicolumn{2}{|c|}{ Doações financeiras } & $\bullet$ & $\circ$ & $\bullet$ & $\circ$ & $\circ$ & $\circ$ & $\circ$ & $\circ$ & $\bullet$ & $\circ$ & $\bullet$ & $\bullet$ & $\circ$ & $\circ$ & $\bullet$ & $\circ$ & $\circ$ & $\bullet$ & 7 \\
\hline \multicolumn{2}{|c|}{ Execução de compras } & $\circ$ & $\bullet$ & $\bullet$ & $\circ$ & $\circ$ & $\circ$ & $\circ$ & $\circ$ & $\circ$ & $\bullet$ & $\circ$ & $\circ$ & $\circ$ & $\circ$ & $\circ$ & $\bullet$ & $\circ$ & $\bullet$ & 5 \\
\hline \multicolumn{2}{|c|}{ Total } & 9 & 9 & 11 & 5 & 5 & 4 & 5 & 6 & 6 & 9 & 7 & 7 & 6 & 7 & 9 & 6 & 6 & 9 & \\
\hline
\end{tabular}


A Tabela 2 traz algumas características adicionais. As quatro primeiras não são binárias, ou seja, é possível que o mesmo sistema atenda a uma ou mais características. Estas características são importantes para avaliar como os sistemas vem sendo desenvolvidos, evidenciando as aplicações em diferentes etapas, sua disponibilidade, e principais setores envolvidos no processo.

A primeira característica abordada refere-se as etapas do ciclo do desastre nas quais os sistemas atuam. É necessário frisar que apesar de já consolidada na literatura as nomenclaturas utilizadas quanto a divisão das fases de desastres, uma discussão que ainda existe é relativa à incerteza sobre o início e término de cada uma delas (Neal, 1997; Coetzee e Van Niekerk, 2012), e por isso possui um traço subjetivo, visto que nos artigos, relatórios e informações disponíveis analisados sobre as ferramentas não há essa informação explícita. Em relação a esta característica pode-se observar a considerável ênfase do desenvolvimento de ferramentas para a fase de resposta. John (2017) evidencia em sua revisão de estudos empíricos na cadeia de suprimentos humanitária que há uma lacuna em estudos empíricos envolvendo a fase de mitigação e a necessidade de desenvolvimento de ferramentas para esta fase, corroborando com os resultados encontrados nesta revisão, onde apenas 5 das 18 ferramentas avaliadas possuem aplicação nesta fase.

A segunda característica refere-se à disponibilidade da ferramenta, onde pode-se verificar o predomínio de ferramentas proprietárias/comerciais, o que deveria ser evitado no campo humanitário, segundo Lickfett et al. (2008). Os autores afirmam que tecnologias opensource são aliadas em eficiência, além de aumentar a possibilidade de colaboração e ganhos em termos de interoperabilidade e modularidade, portanto deveria existir uma maior quantidade de ferramentas com essa característica.

A terceira característica refere-se ao nível de implementação do software percebe-se que a maioria dos sistemas analisados já estão na fase de implementação. Vale ressaltar que segundo Howard e MacEachren (1996) o nível de maturidade em cada uma das etapas pode ser diferente, portanto neste nível de implementação, por exemplo, estão inclusos sistemas já utilizados em situações reais, como também protótipos ainda em teste.

A quarta característica considerada é quanto ao tipo de aplicação, os resultados encontrados reforçam uma tendência destacada por Poblet, GarcíaCuesta e Casanovas (2013) e por Bacigalupe e Velasco-Martin (2018) sobre o uso da interface web no desenvolvimento de sistemas, justificada pela evidente necessidade das atualizações de informações em tempo real. Outra interessante 
observação é como a utilização de interface mobile é capaz de potencializar a participação popular. Dos 6 sistemas com esta característica, todos também apresentam algum nível de participação popular.

Vale observar ainda a inexistente participação da iniciativa privada no desenvolvimento das ferramentas analisadas. Pode ser uma oportunidade para avanços, principalmente no que concerne o aporte financeiro. É importante destacar a atuação das instituições acadêmicas em termos de desenvolvimento, das 18 ferramentas, 12 foram desenvolvidas por pesquisadores acadêmicos. No que concerne a participação popular ainda há um caminho a ser percorrido pelas ferramentas. Esse fato pode ser atribuído a dificuldade de validar informações externas, contudo é uma importante forma de engajamento popular, que pode inclusive fomentar doações e voluntariado (Bacigalupe e Velasco-Martin, 2018).

Os dois últimos itens foram destacados por serem duas características centrais do objeto desta pesquisa e por constituir formas de minimizar os problemas de convergência de materiais e gerenciamento de doações tratados ao longo deste estudo. A baixa quantidade de ferramentas com essas características (7 e 5, respectivamente) demonstra que ainda há uma lacuna que pode ser preenchida e gerar melhorias para o estado da arte dos sistemas em LH. É nestas lacunas que o SmartDonation possui seu principal potencial de contribuição não somente para a literatura acadêmica, mas sobretudo para o campo prático da gestão de desastres.

Neste contexto, o SmartDonation apresenta importantes características que contribuem para uma maior participação popular através de sistemas de informação, e que por meio de sua interface web possibilita concomitantemente troca de informações e de forma mais ágil e disponibilização de recursos em um período de tempo mais curto, contudo ainda pode avançar no aspecto da disponibilidade da ferramenta e potencializar seu impacto.

Desse modo, a partir da RSL obtém-se as principais funcionalidades de sistemas de gerenciamento em operações humanitárias e características importantes que podem facilitar o acesso e o avanço do desenvolvimento de sistemas em LH. É possível ainda corresponder as categorias citadas por Nielsen (1994) acerca da aceitabilidade prática do software, como custo, compatibilidade, confiabilidade, que são diretamente relacionadas com as funcionalidades custos diretos e custos indiretos, cross-linking e interoperabilidade, e segurança da informação. Logo, do ponto de vista funcional o SmartDonation atende à algumas das categorias tradicionais da aceitabilidade prática. 


\section{5 \\ Estudo de caso}

O presente capítulo apresenta o estudo de caso sobre a aceitabilidade do sistema desenvolvido, pelas potenciais instituições administradoras. Como público-alvo foram consideradas organizações humanitárias que atuam diretamente no auxílio a vítimas de desastres e também instituições que atuam na assistência continuada de pessoas em situação de vulnerabilidade social, por entender que essas instituições também podem apresentar dificuldades no gerenciamento de doações e no processo de compras de suprimentos.

A análise do estudo utiliza os elementos apresentados no capítulo 2 , a saber: doações, processo de compras e avaliação do software. As subseções deste capítulo visam entender as similaridades e diferenças de cada instituição no que tange esses elementos. Sendo essencial compreender se há um processo estruturado de compras e doações, os maiores desafios relacionados e ações conduzidas. Mendes et al. (2019b) fazem o detalhamento dos processos de doação e aquisição de suprimentos de cada uma das instituições. O Quadro 5 resume as unidades de análise selecionadas para o estudo de caso . 
Quadro 5 - Unidades de análise do estudo de caso

\begin{tabular}{|c|c|c|c|c|}
\hline Instituição & Área de atuação & $\begin{array}{c}\text { Cargo do } \\
\text { entrevistado }\end{array}$ & $\begin{array}{c}\text { Tempo } \\
\text { no cargo }\end{array}$ & Campanhas em que atuou \\
\hline$A$ & $\begin{array}{l}\text { Uma das principais entidades de assistência às vítimas de desastres, além de } \\
\text { desenvolver projetos de assistência contínuos visando a melhoria das } \\
\text { comunidades e pessoas em situação de vulnerabilidade }\end{array}$ & $\begin{array}{l}\text { Coordenador de } \\
\text { programas } \\
\text { humanitários }\end{array}$ & 3 anos & $\begin{array}{l}\text { Projeto Zika, situação de desastres e } \\
\text { inundações em Alagoas, situação de } \\
\text { imigração na Colômbia, epidemia de } \\
\text { febre amarela }\end{array}$ \\
\hline $\mathrm{B}$ & $\begin{array}{l}\text { Organização da Sociedade Civil de Interesse Público (OSCIP) - que, por meio } \\
\text { da articulação em rede, se constitui, como uma plataforma que articula } \\
\text { diversos atores. Nela, pessoas físicas e jurídicas encontram resposta para } \\
\text { investir recursos financeiros, humanos, materiais e conhecimentos técnicos a } \\
\text { fim de promover o desenvolvimento social. Atua como intermediária entre } \\
\text { ONGs e doadores. }\end{array}$ & $\begin{array}{l}\text { Consultor de } \\
\text { projetos }\end{array}$ & 1 ano & $\begin{array}{l}\text { Conhece significativamente } \\
\text { processo de entrada de doações e } \\
\text { todas as campanhas pontuais }\end{array}$ \\
\hline $\mathrm{C}$ & $\begin{array}{l}\text { Unidade vinculada à uma Universidade, que atende as demandas de uso dos } \\
\text { espaços comuns no campus, avaliando propostas internas e externas de } \\
\text { intervenções que envolvam a imagem da Universidade e viabilizando a } \\
\text { realização daquelas que condizem com os preceitos da Instituição. Procura } \\
\text { estimular a participação da comunidade acadêmica em ações sociais através } \\
\text { da produção de atividades que despertem o comportamento voluntário e } \\
\text { cidadão }\end{array}$ & $\begin{array}{l}\text { Coordenadora de } \\
\text { atividades } \\
\text { comunitárias e } \\
\text { culturais }\end{array}$ & 8 anos & $\begin{array}{l}\text { Campanhas de doação de sangue, } \\
\text { campanhas de arrecadação de } \\
\text { alimentos e outros itens. }\end{array}$ \\
\hline $\mathrm{D}$ & $\begin{array}{l}\text { Atua na garantia do direito à moradia nas favelas mais precárias e invisíveis } \\
\text { em vários países do continente. Para superar a pobreza multidimensional nas } \\
\text { comunidades, desenvolve uma metodologia de trabalho que busca fortalecer } \\
\text { as capacidades comunitárias de identidade, organização e trabalho em rede, } \\
\text { engajando os moradores e as moradoras das comunidades e mobilizando } \\
\text { jovens voluntários e voluntárias por meio de um modelo de intervenção } \\
\text { contínuo e Programas Sociais que geram soluções concretas de melhorias das } \\
\text { condições de moradia e habitat }\end{array}$ & $\begin{array}{l}\text { Coordenadora de } \\
\text { alojamentos }\end{array}$ & 8 anos & $\begin{array}{l}\text { Construções em comunidades do Rio } \\
\text { de Janeiro }\end{array}$ \\
\hline$E$ & $\begin{array}{l}\text { OSCIP que atua em comunidades carentes nas cidades de São Paulo, Rio de } \\
\text { Janeiro e Petrópolis, tendo como público alvo crianças de } 4 \text { anos até jovens } \\
\text { de } 18 \text { anos. Os diversos programas e iniciativas se projetam nas comunidades } \\
\text { onde se realizam as atividades que fomentam o desenvolvimento integral da } \\
\text { pessoa através de um serviço de promoção humana }\end{array}$ & $\begin{array}{l}\text { Supervisora } \\
\text { financeira e } \\
\text { coordenador de } \\
\text { planejamento }\end{array}$ & 1 ano & $\begin{array}{l}\text { Campanhas Solidárias de Páscoa, } \\
\text { Dia das Crianças, Natal. Além disso } \\
\text { promove cursos profissionalizantes, } \\
\text { projetos e programas de educação } \\
\text { integral e esporte }\end{array}$ \\
\hline
\end{tabular}




\subsection{Síntese do processo de doações nas instituições}

As instituições analisadas possuem distintas frentes de atuação e também apresentam processos distintos de doações, no Quadro 6 é apresentada uma síntese sobre as questões referentes a doações em cada uma das instituições. É possível perceber que todas possuem desafios a serem superados no que tange o processo de gerenciamento de doações. Duas instituições (C e D) apontam como maiores dificuldades o processo de armazenagem de suprimentos, enquanto a instituição $E$ indica o controle das datas de validade como um problema considerável. Todas aceitam doações financeiras, exceto a instituição $C$, por questões internas da organização ao qual é associada. Ao verificar informações disponibilizadas pela instituição A em seu site, é possível verificar que os doadores podem realizar doações online, podendo ser realizada mensalmente nos valores de 15,30 ou 100 reais ou qualquer valor de maneira avulsa. Não foi possível verificar através de documentos oficiais a predominância do tipo de doação, que não estava disponível no momento da consulta na página da instituição, apesar de existir uma área do site dedicada a transparência e prestação de contas de doações. Já na instituição $B$, para pessoas físicas é possível doar qualquer valor a partir de 5 reais, ou valores mensais fixos entre 20 e 120 reais. Há ainda a opção anual, baseada na declaração de imposto de renda, que direciona $6 \%$ para para a instituição. Há campanhas direcionadas estritamente para empresas, sendo seis campanhas permanentes voltadas exclusivamente para doações monetárias, e apenas uma para itens materiais. O tipo de doações majoritárias é do tipo monetária, essa informação é corroborada pelos resultados financeiros de 2018 , no qual as doações materiais correspondem a $20 \%$ do total de doações. É possível efetuar doações ao longo de todo ano a qualquer momento de maneira pontual ou recorrente, se tornando doador fixo. Sobre a principal forma de doação, a entrevistada afirma que a financeira é mais comum, o que pode ser explicado pela proximidade dos doadores e voluntários, que gera um senso de confiabilidade maior quanto ao destino do dinheiro, segundo a mesma. Esta informação é corroborada pelos dados do Demonstrativo de Resultado em 2017 que aponta uma superioridade relevante das doações financeiras em relação doações de produtos e permuta. Na instituição E é possível apenas visualizar as informações bancárias, e o doador é direcionado para um formulário no qual preenche seus dados pessoais e o valor de contribuição mensal, e a data de vencimento do boleto. Assim, o doador recebe os boletos a serem pagos, via e-mail. Ao falar sobre o tipo de doação predominante, a 
entrevistada afirma que atualmente há superioridade de doações financeiras inclusive nas campanhas solidárias. Essa informação pôde ser confirmada no relatório de transparência da instituição. É unanimidade entre as instituições o recebimento de itens não prioritários, como Islam (2013) aponta ser uma prática comum entre organizações de assistência. Porém apenas uma tem uma política bem definida de não recebimento caso se identifique a data de expiração próxima ou item danificado. Constata-se, portanto, a afirmação de Islam (2013), de que as instituições acolhem este tipo de doação a fim de não desperdiçar doações futuras, e apenas a instituição $D$ não considera ter custos logísticos associados a essa política. Duas das instituições ( $\mathrm{A}$ e E) não possuem uma conformidade em relação a predominância do tipo de doação, já a instituição $C$ que atualmente só recebe doações materiais e a instituição $B$ e $D$ afirmam receber maior aporte de doações financeiras. Todas preocupam-se com a divulgação das campanhas e itens necessários, porém não focam na conscientização sobre consequências em decorrência de cada tipo de doação, ratificando a necessidade de engajamento e investimento em campanhas educacionais apontados por Alexander (2013). Todas, exceto a instituição C possuem programas de fidelização de doadores, mas não há uma avaliação em relação a isso, corroborando com Silva e Leiras (2015), como uma lacuna ainda existente nas operações e instituições. 
Quadro 6 - Síntese das questões referentes a doações

\begin{tabular}{|c|c|c|c|c|c|}
\hline & A & B & C & $\mathrm{D}$ & $E$ \\
\hline $\begin{array}{l}\text { 1. O gerenciamento de } \\
\text { doações é um desafio } \\
\text { para a instituição? }\end{array}$ & $\begin{array}{l}\text { Sim. Apesar da ampla } \\
\text { atuação e experiência, } \\
\text { ainda há oportunidades de } \\
\text { melhoria. }\end{array}$ & $\begin{array}{|lrr|}\text { Sim. Por ser } & \text { uma } \\
\text { instituição intermediária } \\
\text { entre doadores e } & \text { outras } \\
\text { instituições, } & \text { existem } \\
\text { muitas doações } & \text { que } \\
\begin{array}{l}\text { precisam } \\
\text { direcionamento. }\end{array} & \text { de } \\
\end{array}$ & $\begin{array}{l}\text { Apesar do pequeno } \\
\text { volume de doações, a } \\
\text { instituição tem problemas } \\
\text { com armazenagem. }\end{array}$ & $\begin{array}{l}\text { Gerenciar doações segue } \\
\text { sendo um problema a ser } \\
\text { superado, já que é parte } \\
\text { essencial da logística para a } \\
\text { realização das atividades fim. } \\
\text { Uma dificuldade apontada é o } \\
\text { armazenamento }\end{array}$ & $\begin{array}{l}\text { Sim, segue sendo um desafio } \\
\text { à medida que há expansão de } \\
\text { projetos e inclusão de novos. } \\
\text { O maior problema que } \\
\text { enfrentam hoje é controlar as } \\
\text { datas de expiração das } \\
\text { doações }\end{array}$ \\
\hline $\begin{array}{l}\text { 2. Como é o processo } \\
\text { atual de doações? }\end{array}$ & $\begin{array}{|lrr|}\text { As doações podem ser de } \\
\text { natureza financeira } & \text { e } \\
\text { material. As financeiras são } \\
\text { efetuadas pelo site da } \\
\text { própria instituição e as } \\
\text { materiais são recebidas na } \\
\text { sede local ou recolhidas em } \\
\text { pontos de arrecadação. } \\
\text { Ambas são potencializadas } \\
\text { quando há extensiva } \\
\text { divulgação do desastre }\end{array}$ & \begin{tabular}{|l|} 
Doações de natureza \\
material e financeira. As \\
financeiras são efetuadas \\
pelo site da própria \\
instituição, já as materiais \\
são recebidas na própria \\
instituição ou recolhidas \\
em local combinado. Há \\
doações advindas de \\
campanhas, bem como \\
avulsas e espontâneas
\end{tabular} & $\begin{array}{l}\text { A instituição não atende } \\
\text { um público único e } \\
\text { específico faz ações em } \\
\text { decorrência de alguma } \\
\text { situação emergencial ou } \\
\text { por indicação da } \\
\text { comunidade acadêmica. } \\
\text { Atualmente só recebe } \\
\text { doações materiais. }\end{array}$ & $\begin{array}{l}\text { As doações são feitas baseadas } \\
\text { em uma lista de suprimentos } \\
\text { fundamentada na quantidade } \\
\text { de pessoas participantes da } \\
\text { construção. Logo a captação só } \\
\text { começa após o encerramento } \\
\text { das inscrições. As doações } \\
\text { podem ser de natureza material } \\
\text { ou financeira e são efetuadas } \\
\text { diretamente aos responsáveis } \\
\text { pela arrecadação. }\end{array}$ & $\begin{array}{l}\text { Há duas frentes de atuação, } \\
\text { uma para a manutenção da } \\
\text { instituição e programas } \\
\text { realizados ao longo do ano e } \\
\text { campanhas sazonais na qual } \\
\text { as doações possuem maior } \\
\text { fluxo. As doações financeiras } \\
\text { podem ser feitas através do } \\
\text { site da instituição. }\end{array}$ \\
\hline $\begin{array}{l}\text { 3. Há recebimento de } \\
\text { suprimentos } \quad \text { não } \\
\text { prioritários } r \text { ou } \\
\text { inutilizáveis. Se sim, } \\
\text { qual o procedimento } \\
\text { com os mesmos? }\end{array}$ & $\begin{array}{l}\text { Há um considerável volume, } \\
\text { pois as pessoas doam muito } \\
\text { e de tudo, sem se preocupar } \\
\text { com os itens que são } \\
\text { divulgados previamente. A } \\
\text { orientação geral é receber } \\
\text { os itens ainda que não } \\
\text { sejam urgentes. }\end{array}$ & $\begin{array}{l}\text { Itens não prioritários são } \\
\text { recebidos normalmente, } \\
\text { porém para aqueles } \\
\text { danificados ou com data } \\
\text { de expiração próxima a } \\
\text { orientação é o não } \\
\text { recebimento }\end{array}$ & $\begin{array}{l}\text { Há o recebimento de } \\
\text { itens fora do escopo de } \\
\text { campanhas. } \\
\text { recomendação é receber } \\
\text { e avaliar se pode ser } \\
\text { direcionado para } r \\
\text { instituição atendida ser } \\
\text { redirecionado para outra } \\
\text { instituição. }\end{array}$ & $\begin{array}{l}\text { Há o registro de itens fora do } \\
\text { escopo e ainda que não esteja } \\
\text { dentro do requisitado, são } \\
\text { recebidos e enviados para a } \\
\text { comunidade se avaliarem como } \\
\text { útil para os voluntários } \\
\text { envolvidos. }\end{array}$ & $\begin{array}{l}\text { A instituição os recebe e caso } \\
\text { não sejam úteis são } \\
\text { redirecionados para outras } \\
\text { instituições parceiras ou } \\
\text { utilizadas numa espécie de } \\
\text { bazar solidário para financiar } \\
\text { outros projetos }\end{array}$ \\
\hline $\begin{array}{l}\text { 4. Você considera que } \\
\text { há desperdício e/ou } \\
\text { excesso de } \\
\text { suprimentos e mão-de- } \\
\text { obra para lidar com os } \\
\text { itens não prioritários, } \\
\text { causando custos } \\
\text { logísticos extras? }\end{array}$ & $\begin{array}{l}\text { Sim. O processo de triagem } \\
\text { é um dos mais demorados e } \\
\text { que ocupa maior quantidade } \\
\text { de recursos humanos nas } \\
\text { operações. Além de alguns } \\
\text { itens causarem custos } \\
\text { logísticos com transporte } \\
\text { até no caso de descarte }\end{array}$ & $\begin{array}{l}\text { Sim. Em geral itens fora } \\
\text { do escopo advém de } \\
\text { doações inesperadas e } \\
\text { como a instituição não } \\
\text { dispõe de espaço físico } \\
\text { considerável, acaba } \\
\text { sendo um problema } \\
\text { logístico a ser superado. }\end{array}$ & \begin{tabular}{|lr} 
Não, por conta do baixo \\
volume de doações. \\
Contudo com o aumento \\
do número r de \\
campanhas r pode \\
ocasionalmente \\
acontecer.
\end{tabular} & $\begin{array}{l}\text { Sim, e contribui para um custo } \\
\text { extra principalmente em } \\
\text { recursos humanos no processo } \\
\text { de triagem, armazenagem, e } \\
\text { transporte até o local }\end{array}$ & $\begin{array}{l}\text { Essa política acarreta custos } \\
\text { extras em recursos humanos } \\
\text { no processo de triagem, } \\
\text { principalmente. }\end{array}$ \\
\hline
\end{tabular}

(continua) 
Quadro 6 - Fina

\begin{tabular}{|c|c|c|c|c|c|}
\hline $\begin{array}{lr}5 . \quad \text { Durante } & \text { as } \\
\text { campanhas } & \text { a } \\
\text { instituição recebe } \\
\text { maior doação } & \text { de } \\
\text { suprimentos } & \\
\text { (materiais) } & \text { ou } \\
\text { dinheiro? } & \end{array}$ & $\begin{array}{l}\text { Não há uma conformidade } \\
\text { em todos os casos, portanto } \\
\text { não há como definir a } \\
\text { predominância. }\end{array}$ & $\begin{array}{l}\text { Há campanhas } \\
\text { exclusivas para ambos os } \\
\text { tipos de doação, porém a } \\
\text { maior parte dos recursos } \\
\text { de assistência provém de } \\
\text { doações financeiras }\end{array}$ & Somente materiais & 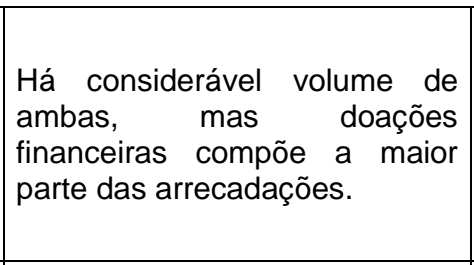 & $\begin{array}{lr}\text { Em geral campanhas } \\
\text { pontuais, recebem } \\
\text { majoritariamenter itens } \\
\text { materiais, enquanto ao logo } \\
\text { do ano há maior concentração } \\
\text { de doações financeiras }\end{array}$ \\
\hline $\begin{array}{lrr}\text { 6. A organização } \\
\text { possui ações de } \\
\text { conscientização sobre } \\
\text { como doar er as } \\
\text { consequências } \quad \text { de } \\
\text { cada tipo de doação } \\
\text { para a instituição e } \\
\text { para os beneficiários? }\end{array}$ & $\begin{array}{|lrr|}\text { Sim. A equipe de } & \text { demunicação } & \text { procura } \\
\text { comas } & \text { divulgar listas com itens } \\
\text { aceitos e formas de doação, } \\
\text { além de recursos } & \text { como } \\
\text { palavras-chave em redes } \\
\text { sociais. }\end{array}$ & $\begin{array}{|lr|}\text { Há um } & \text { melhor } \\
\text { direcionamento } & \text { para } \\
\text { pessoas jurídicas } & \text { para } \\
\text { conscientização } & \text { e } \\
\text { assertividade } & \text { das } \\
\text { doações, } & \text { há } \\
\text { oportunidades } & \text { de } \\
\text { melhoria com } & \text { pessoas } \\
\text { físicas. } & \\
\end{array}$ & $\begin{array}{l}\text { Há preocupação com a } \\
\text { divulgação dos itens a } \\
\text { serem recebidos, não } \\
\text { sobre possíveis } \\
\text { problemas de doações } \\
\text { não solicitadas. }\end{array}$ & $\begin{array}{l}\text { Há a divulgação do que é } \\
\text { necessário, quantidade, quais } \\
\text { os pontos de arrecadação, etc., } \\
\text { mas não exister uma } \\
\text { preocupação em demonstrar } \\
\text { que uma doação fora do escopo } \\
\text { pode prejudicar em algum nível } \\
\text { a logística. }\end{array}$ & $\begin{array}{l}\text { Existe a divulgação da } \\
\text { campanha, mas não há uma } \\
\text { espécie de guia ou manual } \\
\text { que auxilie o doador, também } \\
\text { não acredita que os doadores } \\
\text { tenham conhecimento sobre } \\
\text { os transtornos que uma } \\
\text { doação "errada" pode causar. }\end{array}$ \\
\hline $\begin{array}{lr}\text { 7. Há algum tipo de } \\
\text { avaliação } & \text { e/ou } \\
\text { programa } & \text { de } \\
\text { fidelização } & \text { de } \\
\text { doadores? } & \end{array}$ & $\begin{array}{l}\text { Avaliação não, mas há a } \\
\text { possibilidade de realizar } \\
\text { pagamentos fixos mensais, } \\
\text { o que de alguma forma traz } \\
\text { a fidelização de doadores. }\end{array}$ & $\begin{array}{l}\text { Avaliação não, mas } \\
\text { programa de fidelização } \\
\text { sim, com pagamentos } \\
\text { fixos mensais. }\end{array}$ & $\begin{array}{l}\text { Não. A preocupação da } \\
\text { instituição nesse sentido } \\
\text { é divulgar internamente } \\
\text { quais departamentos e } \\
\text { movimentos já aderiram à } \\
\text { campanha como forma } \\
\text { de incentivar outros a } \\
\text { participarem. }\end{array}$ & $\begin{array}{l}\text { Há essa possibilidade de } \\
\text { fidelização, mas os recursos } \\
\text { são direcionados para outros } \\
\text { programas da instituição. Este } \\
\text { ainda é pouco estruturado e não } \\
\text { conta com essa possibilidade }\end{array}$ & $\begin{array}{l}\text { Há um programa de } \\
\text { fidelização para doações pelo } \\
\text { site da instituição realizado via } \\
\text { pagamento eletrônico ou por } \\
\text { cadastro que é enviado a } \\
\text { instituição e a mesma envia a } \\
\text { cobrança mensalmente para } \\
\text { o doador via e-mail }\end{array}$ \\
\hline $\begin{array}{lr}\text { 8. De que maneira é } \\
\text { realizado } & 0 \\
\text { acompanhamento do } \\
\text { processo de doações? }\end{array}$ & $\begin{array}{l}\text { Apesar de possuir ERP, a } \\
\text { instituição só utiliza o o } \\
\text { módulo financeiro, e utiliza } \\
\text { somente Planilha eletrônica }\end{array}$ & Planilha eletrônica & Planilha eletrônica & Planilha eletrônica & $\begin{array}{l}\text { Manualmente e por meio de } \\
\text { planilha eletrônica }\end{array}$ \\
\hline
\end{tabular}




\subsection{Síntese do processo de compras nas instituições}

As instituições apresentam processos bem distintos entre si, mas também apresentam processos variados de compras dentro da própria instituição a depender do tipo de ocorrência, campanha ou evento. O Quadro 7 traz uma breve síntese sobre os processos de aquisição de suprimentos das instituições com base na seção 2.2. Pode-se observar que apenas "Identificar necessidades" e "Expedir e monitorar entrega" foram citadas por todas. Vale ressaltar ainda, que a instituição A, cita a maioria das etapas, porém enfatiza que a depender da situação, algumas não são realizadas. O detalhamento dos processos de cada uma das instituições pode ser observado em Mendes et al. (2019b)

Quadro 7 - Síntese das etapas do processo de compras por instituição

\begin{tabular}{|c|c|c|c|c|c|}
\hline Etapas & A & B & C & D & $\mathbf{E}$ \\
\hline Avaliar situação & $x$ & $x$ & & $x$ & $x$ \\
\hline Identificar necessidades & $x$ & $x$ & $x$ & $x$ & $x$ \\
\hline Priorizar necessidades & $x$ & $x$ & & & \\
\hline Planejar aquisições & $x$ & & & $x$ & $x$ \\
\hline \multicolumn{6}{|l|}{ Identificar Fontes } \\
\hline Encomendar produtos emergenciais & $x$ & & & & \\
\hline Especificar produtos especiais & $x$ & & & & \\
\hline Pedir produtos emergenciais em estoque & $x$ & & & & \\
\hline Especificar recursos humanos necessários & $x$ & $x$ & & & $x$ \\
\hline Especificar recursos financeiros necessários & $x$ & $x$ & & & $x$ \\
\hline Realizar cotação de produtos & $x$ & $x$ & & & \\
\hline Realizar cotação de recursos de transporte & $x$ & $x$ & & & \\
\hline Consolidar solicitação de produtos & $x$ & & & & \\
\hline Mobilizar recursos nos armazéns de fornecedores & $x$ & & & & \\
\hline Mobilizar recursos nos armazéns estratégicos & $x$ & & & & \\
\hline Comunicar as prioridades aos doadores & $x$ & & $x$ & $x$ & $x$ \\
\hline Receber doações & $x$ & & $x$ & $x$ & $x$ \\
\hline Justificar solicitações especiais & $x$ & & & & \\
\hline Confirmar e validar compra (local e externa) & $x$ & $x$ & & & \\
\hline Comprar produtos locais e externos & $x$ & & & $x$ & $x$ \\
\hline Contratar recursos de transporte & $x$ & & $x$ & & \\
\hline Avaliar e escolher & $x$ & & & & \\
\hline Expedir e monitorar entrega & $x$ & $x$ & $x$ & $x$ & $x$ \\
\hline Revisar e agir & $x$ & $x$ & & $x$ & $x$ \\
\hline
\end{tabular}


O Quadro 8 apresenta uma síntese de questões adicionais referentes ao processo de compras abordadas no estudo de caso.

Nenhuma das instituições possui um método bem definido de previsão de demanda. A instituição A utiliza fontes de informações secundárias, ou seja, utiliza dados fornecidos por outras instituições. As demais, por lidarem com projetos e públicos bem definidos tem uma demanda previamente conhecida, em geral. Com exceção da instituição $\mathrm{C}$, todas as organizações estabelecem metas para campanhas e itens. As cinco instituições afirmam que os itens recebidos, em geral, são capazes de atender a demanda, mas todos relataram já ter ocorrido desequilíbrio entre o programado e o executado. A instituição $D$ frisa que as doações chegam a ser superiores a meta estabelecida, que pode ser explicada pelo recebimento de doações de natureza material e financeira, porém somente as doações materiais tem metas bem delimitadas, as financeiras são utilizadas somente no fim da campanha para compra dos itens não arrecadados através de doações materiais.

Nenhuma das instituições avalia os fornecedores, o que mostra uma fragilidade na verificação de níveis de serviço ao longo das campanhas. No que tange a eficácia do gerenciamento atual, somente a instituição $E$ considera sua forma de gerenciamento ineficaz. Contudo, todas entendem que há oportunidades de melhorias, não só das ferramentas utilizadas, como do macroprocesso como um todo. As instituições $B, D$ e $E$ consideram que doações monetárias para subsidiar os suprimentos necessários para as campanhas é uma maneira mais eficaz de obtenção de recursos, principalmente pela uniformidade e economia com armazenamento. De maneira similar, a instituição $\mathrm{C}$ concorda, porém esbarra em questões hierárquicas da organização que integra. Já a instituição A considera que a depender da localidade, urgência e tipo de ocorrência a maneira mais recomendada pode variar. O interesse pela utilização do sistema é quase unanime, somente o entrevistado da instituição $A$ mostrou-se indeciso, porém seus motivos de apreensão foram igualmente apontados pela instituição $B$, a saber: receio pela aceitação do público, e falta de confiabilidade por não ter sido testado. Já em relação à capacidade, todas possuem as atribuições básicas para receber o sistema. Somente a instituição $C$ esbarra novamente em questões institucionais burocráticas . 
Quadro 8 - Síntese sobre o processo de compras das instituições

\begin{tabular}{|c|c|c|c|c|c|}
\hline & A & B & C & D & $E$ \\
\hline 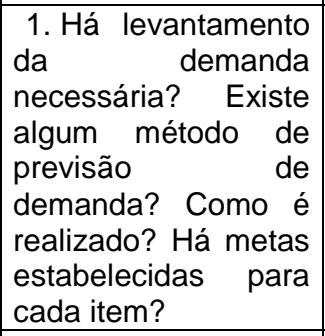 & $\begin{array}{l}\text { A instituição utiliza dados } \\
\text { secundários, daí estabelece } \\
\text { metas para alcançar um número } \\
\text { de itens para compor os kits } \\
\text { emergenciais. Não há um } \\
\text { método bem definido de } \\
\text { previsão, acaba sendo baseado } \\
\text { em experiências anteriores }\end{array}$ & $\begin{array}{l}\text { Não há método de } \\
\text { previsão de demanda } \\
\text { pois a instituição apoia } \\
\text { projetos com públicos } \\
\text { bem definidos em todos } \\
\text { os projetos. Contudo, há } \\
\text { metas estabelecidas em } \\
\text { campanhas específicas. }\end{array}$ & $\begin{array}{lr}\text { Não. As } & \text { campanhas } \\
\text { possuem } & \text { número } \\
\text { estabelecido } & \text { de } \\
\text { pessoas. Também não } \\
\text { há } & \text { metas } \\
\text { estabelecidas } & \text { nem } \\
\text { conformidade } & \text { entre } \\
\text { eles. } & \end{array}$ & $\begin{array}{l}\text { Por se tratar de uma } \\
\text { demanda } \\
\text { determinística as } \\
\text { quantidades são bem } \\
\text { definidas desde o início } \\
\text { da campanha da } \\
\text { arrecadação }\end{array}$ & $\begin{array}{l}\text { Por se tratar demanda } \\
\text { determinística é relativamente } \\
\text { simples de ser mensurada. Há } \\
\text { metas por itens a serem } \\
\text { atingidas em cada campanha. }\end{array}$ \\
\hline $\begin{array}{lr}2 . \text { Os } & \text { itens } \\
\text { recebidos durante as } \\
\text { campanhas são } \\
\text { suficientes para } \\
\text { atender a população } \\
\text { a ser atendida? Há } \\
\text { muita divergência ao } \\
\text { programado com o } \\
\text { que é executado? }\end{array}$ & $\begin{array}{l}\text { É variável. Em geral, o auxílio é } \\
\text { fornecido de maneira suficiente. } \\
\text { Contudo, já ocorreram casos } \\
\text { em que os itens arrecadados } \\
\text { não atenderem a toda a } \\
\text { população atingida sendo } \\
\text { necessária a ação conjunta com } \\
\text { outras filiais com maior } \\
\text { capacidade. }\end{array}$ & $\begin{array}{l}\text { Nem sempre é possível } \\
\text { atingir as metas } \\
\text { estabelecidas. r Já } \\
\text { houveram casos de não } \\
\text { atendimento de uma } \\
\text { parcela do público } \\
\text { inicialmente previsto, } \\
\text { porém o desequilíbrio } \\
\text { não foi considerável, } \\
\end{array}$ & $\begin{array}{l}\text { Não são suficientes em } \\
\text { alguns casos. Em uma } \\
\text { das campanhas o } \\
\text { executado e o } \\
\text { programado divergiram } \\
\text { consideravelmente }\end{array}$ & $\begin{array}{l}\text { Em geral as } \\
\text { campanhas } \\
\text { apresentam } \\
\text { quantidade superior a } \\
\text { necessária. }\end{array}$ & 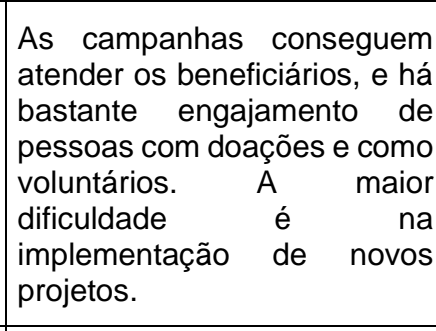 \\
\hline $\begin{array}{l}\text { 3. Há setor de } \\
\text { compras? Quais as } \\
\text { etapas do processo? }\end{array}$ & $\begin{array}{l}\text { Sim. As etapas são descritas } \\
\text { em Mendes et al. (2019b) }\end{array}$ & $\begin{array}{l}\text { Sim. As etapas são } \\
\text { descritas em Mendes et } \\
\text { al. (2019b) }\end{array}$ & $\begin{array}{l}\text { Não. Mas há processo } \\
\text { de aquisição, conforme } \\
\text { descrito em Mendes et } \\
\text { al. (2019b) }\end{array}$ & $\begin{array}{l}\text { Sim. As etapas são } \\
\text { descritas em Mendes } \\
\text { et al. (2019b) }\end{array}$ & $\begin{array}{l}\text { Sim. As etapas são descritas } \\
\text { em Mendes et al. (2019b) }\end{array}$ \\
\hline $\begin{array}{l}\text { 4. Existe avaliação } \\
\text { de fornecedores? }\end{array}$ & $\begin{array}{l}\text { Não existe avaliação de } \\
\text { fornecedores. }\end{array}$ & $\begin{array}{l}\text { Não existe avaliação } \\
\text { sistematizada para nível } \\
\text { de serviço de } \\
\text { fornecedores }\end{array}$ & $\begin{array}{l}\text { Sem processo de } \\
\text { compras, a questão } \\
\text { não se coloca }\end{array}$ & $\begin{array}{l}\text { Não há avaliação de } \\
\text { fornecedores }\end{array}$ & $\begin{array}{l}\text { Não há avaliação de } \\
\text { fornecedores }\end{array}$ \\
\hline 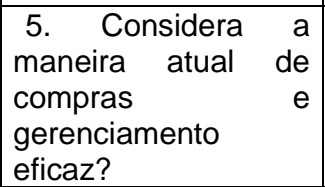 & $\begin{array}{l}\text { Sim, contudo, enfatiza que a } \\
\text { instituição precisa de maior } \\
\text { visibilidade e ser mais prática } \\
\text { com o usuário final }\end{array}$ & $\begin{array}{l}\text { Suficientemente bom } \\
\text { mas tem oportunidade } \\
\text { de melhorias. }\end{array}$ & $\begin{array}{l}\text { Sim. Acredita que para } \\
\text { a demanda e forma de } \\
\text { trabalho atual, é } \\
\text { suficiente }\end{array}$ & $\begin{array}{l}\text { Suficiente para o atual } \\
\text { processo }\end{array}$ & Não \\
\hline
\end{tabular}

(continua) 


\section{Quadro 8 - Final}

\begin{tabular}{|c|c|c|c|c|c|}
\hline $\begin{array}{l}\text { 6. Caso a maior } \\
\text { parte da obtenção de } \\
\text { suprimentos fosse } \\
\text { feita através de } \\
\text { compras subsidiadas } \\
\text { por doações, } \\
\text { considera esta uma } \\
\text { maneira mais eficaz } \\
\text { e eficiente que a } \\
\text { atualmente adotada? }\end{array}$ & $\begin{array}{l}\text { Depende do tipo, localidade, } \\
\text { nível de engajamento dos } \\
\text { doadores, urgência. Quando a } \\
\text { ocorrência é longe de sua } \\
\text { jurisdição é mais eficaz que as } \\
\text { doações financeiras sejam } \\
\text { priorizadas. Ou ainda quando } \\
\text { se trata de desastres de início } \\
\text { lento. }\end{array}$ & $\begin{array}{l}\text { Seria muito mais } \\
\text { vantajoso e fácil para a } \\
\text { instituição, diminuindo } \\
\text { inclusive um dos maiores } \\
\text { problemas da } \\
\text { organização, a } \\
\text { armazenagem }\end{array}$ & $\begin{array}{l}\text { Entende as vantagens } \\
\text { desse modelo de } \\
\text { arrecadação r e } \\
\text { obtenção de itens, mas } \\
\text { esbarra na incerteza } \\
\text { das consequências } \\
\text { reais dessa mudança } \\
\text { para a instituição. }\end{array}$ & \begin{tabular}{|lr} 
Seria muito mais fácil, \\
diminuiria o trabalho \\
dos voluntários fixos, e \\
minimizaria & $a$ \\
dificuldade & de \\
armazenagem por um \\
prazo grande de dias.
\end{tabular} & $\begin{array}{l}\text { Sim, pela uniformização que } \\
\text { pode ser dada, não gerando } \\
\text { conflito entre os beneficiários, } \\
\text { além do custo ser menor se } \\
\text { puder comprar em grandes } \\
\text { quantidades }\end{array}$ \\
\hline $\begin{array}{l}\text { 7. Há interesse da } \\
\text { instituição pelo } \\
\text { sistema? }\end{array}$ & $\begin{array}{l}\text { Indeciso. O principal motivo é o } \\
\text { receio pela não aceitação do } \\
\text { público em geral. Outros dois } \\
\text { motivos citados, é a falta de } \\
\text { confiabilidade no sistema, e o } \\
\text { grau de satisfação já alcançada } \\
\text { com o modo de gerenciamento } \\
\text { atual }\end{array}$ & \begin{tabular}{|lr} 
Sim, mas aponta a \\
cultura da organização \\
como um entrave na \\
adesão. Além da \\
preocupação com a \\
aceitação do público, e \\
baixa confiabilidade por \\
não ter sido testado em \\
situação real \\
\end{tabular} & 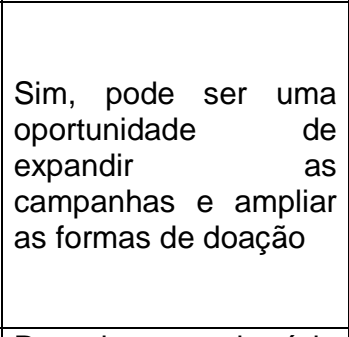 & Sim, bastante & Sim, muito. \\
\hline $\begin{array}{l}\text { 8. Capacidade de } \\
\text { receber o sistema }\end{array}$ & $\begin{array}{l}\text { Possui domínio próprio, } \\
\text { servidor dedicado, setor de TI e } \\
\text { pessoas disponíveis para } \\
\text { gerenciar } \\
\text { o sistema }\end{array}$ & $\begin{array}{l}\text { O Instituto possui } \\
\text { domínio próprio, servidor } \\
\text { dedicado, setor de TI e } \\
\text { pessoas disponíveis } \\
\text { para gerenciar o } \\
\text { sistema. }\end{array}$ & \begin{tabular}{|lr} 
Possui & domínio \\
próprio, & servidor \\
dedicado, suporte de TI \\
e pessoas disponíveis \\
para operacionalizar o \\
sistema de & maneira \\
integral. & Contudo, \\
enfatiza um problema \\
no que tange a falta de \\
autonomia r & para \\
tomadas de & decisão \\
em um rrimeiro \\
momento. & \\
\end{tabular} & $\begin{array}{lr}\text { Possui romínio } \\
\text { próprio, possui servidor } \\
\text { dedicado. Apesar de } \\
\text { não ter umsem setor } \\
\text { exclusivo de } & \text { TI, porém } \\
\text { existem r muitos } \\
\text { voluntários r fixos } \\
\text { capacitados na área e } \\
\text { pessoas disponíveis } \\
\text { para operacionalizar o } \\
\text { sistema. }\end{array}$ & $\begin{array}{l}\text { Possui domínio próprio. A } \\
\text { entrevistada não soube } \\
\text { afirmar se possui servidor } \\
\text { dedicado, mas acredita que } \\
\text { seria possível adquirir, porém } \\
\text { não há suporte de TI, nem } \\
\text { perspectiva para investir } \\
\text { imediatamente. Mas existem } \\
\text { pessoas disponíveis para } \\
\text { receber treinamento e } \\
\text { gerenciar o sistema }\end{array}$ \\
\hline
\end{tabular}




\subsection{Teste de usabilidade}

Nesta seção são apresentados os resultados do teste de usabilidade, com a evolução, percepção e parecer dos usuários durante a execução das tarefas

\subsubsection{Execução das tarefas}

Os testes de usabilidade foram aplicados entre os dias 18 de dezembro de 2018 e 22 de janeiro de 2019 juntamente com as entrevistas, e realizados com os mesmos entrevistados. O teste é dividido em 10 tarefas, a fim de simular etapas simples para abertura de uma campanha. As tarefas são: efetuar login no sistema; cadastrar produtos; atualizar índices de consumo; cadastrar evento; identificar necessidades de suprimentos; solicitar cotação; calcular custos unitários; publicar campanha, verificar status da campanha no painel de controle e enviar pedido aos fornecedores. Cada tarefa foi avaliada quanto ao sucesso ou fracasso de execução e nível de facilidade classificada pelo usuário.

A tarefa 1 consiste em realizar o login, supondo que o usuário já tenha sido cadastrado no sistema como administrador que são informados aos usuários no momento do teste. Todos os usuários executaram a tarefa $1 \mathrm{com}$ facilidade.

A tarefa 2 consiste no cadastro de dois produtos pelo usuário, a saber: água e kit médico. Para cadastrar o produto faz-se necessário da descrição, categoria, unidade de medida, medida e se necessita de refrigeração. Optou-se por não informar cada um dos dados a serem preenchidos a fim de captar a interpretação dos usuários em cada um dos campos e se os termos utilizados poderiam causar algum tipo de confusão ou dificuldade para a execução da tarefa. Como pode ser observado na Tabela 3 , três dos cinco usuários executaram a tarefa sem dificuldades, ao contrário dos últimos dois. Ambos relataram confusão na compreensão do campo Medida, que indica que o termo usado ou a disposição na ordem do preenchimento pode ser repensada. No primeiro momento este erro de interpretação pode parecer inofensivo, mas pode gerar erro em cascata, ocasionando problemas no dimensionamento de pedidos que podem passar despercebidos ao usuário acarretando em custos extras, o que é exatamente um dos problemas que o sistema visa minimizar. Apesar dos demais usuários terem executado a tarefa e a considerado fácil o usuário $E$ não seguiu estritamente as instruções, dessa forma cadastrou um produto não solicitado, que se encaixa nas campanhas da instituição. A aplicadora do teste não interviu.

A tarefa 3 consiste em atualizar os índices de consumo, utilizados para facilitar o dimensionamento da demanda para atendimento de uma determinada 
população. Os índices estipulados no teste foram: 2 litros / pessoa afetada / dia e 1 kit médico / pessoa enferma / 5 dias. Apenas o usuário E, além de completar a tarefa, a classificou como muito fácil, ao contrário dos demais, que a classificaram com nível de dificuldade intermediário. Os principais pontos relatados pelos usuários foram a dificuldade em localizar em que local os índices de consumo deveriam ser atualizados.

A tarefa 4 consiste em realizar o cadastro do evento com todas as informações relevantes. Todos os usuários consideraram a tarefa fácil.

A tarefa 5 refere-se à identificação das necessidades de suprimentos, ou seja, a quantidade necessária para atender as pessoas pelos dias estipulados de assistência. Essa tarefa tem um grau de dificuldade maior segundo os usuários. Os principais problemas e dificuldades encontrados foram: dificuldade em localizar o local no qual as informações deveriam ser inseridas; dificuldade em diferenciar quais campos referiam-se à inserção das quantidades manualmente e ao cálculo automático baseado nas informações anteriormente preenchidas. Posicionamento do botão "Atualizar necessidades" pouco intuitivo.

A tarefa 6 refere-se à solicitação de cotação para os fornecedores. É possível observar que grande parte dos usuários concluiu a tarefa, porém com dificuldade e houve inclusive uma desistência nesta tarefa. Os problemas encontrados incluem a dificuldade em localizar onde fazer a solicitação de cotações; falta de entendimento sobre os "Estados da Operação". Outro ponto é o não aparecimento do evento cadastrado ao tentar cadastrar uma cotação manualmente, o que não se configura apenas como um ponto a ser melhorado, mas um erro que pode comprometer a utilização do sistema. Além dos pontos citados, há ainda uma importante questão: para solicitar a cotação deveria ser necessário a seleção dos produtos a serem cotados antes que o botão "Solicitar cotações" estivesse habilitado. Durante o teste o usuário E e A conseguiram clicar no botão "Solicitar a cotação" sem que fosse necessária a seleção dos produtos, e receberam uma mensagem confirmando o envio. Contudo, os produtos não apareceram como solicitados para os fornecedores já cadastrados.

A tarefa 7 consiste no cálculo dos custos unitários e consequentemente no preço final do consumidor. Basicamente é um botão que soluciona a fórmula (1), contudo quase todos os usuários desistiram do teste nesta etapa, em grande parte pelos problemas encontrados na tarefa anterior. O usuário $\mathrm{E}$ apesar de ter executado a tarefa a considerou de dificuldade mediana.

A tarefa 8 consiste na publicação efetiva da campanha, tornando-a disponível para o usuário doador. Foi facilmente executada pelo usuário. 
A tarefa 9 refere-se à verificação do status da campanha no painel de controle, que deve estar aberta e disponível para o usuário. A tarefa foi facilmente executada.

A tarefa 10 consiste no envio dos pedidos aos fornecedores e foi realizada facilmente pelo usuário. O resumo do desempenho das tarefas pode ser observado na Tabela 3

Tabela 3 - Resumo do desempenho dos usuários

\begin{tabular}{|c|c|c|c|c|c|c|c|c|c|c|}
\hline & \#1 & $\# 2$ & \#3 & \#4 & $\# 5$ & \#6 & \#7 & \#8 & \#9 & $\# 10$ \\
\hline $\begin{array}{l}\text { A } \\
\text { B } \\
\text { C } \\
\text { D } \\
\text { E }\end{array}$ & $\begin{array}{l}8 \\
8 \\
8 \\
8\end{array}$ & $\begin{array}{l}8 \\
8 \\
8 \\
8\end{array}$ & 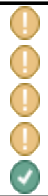 & $\begin{array}{l}8 \\
8 \\
8 \\
8\end{array}$ & $\begin{array}{l}\text { (1) } \\
\text { (1) } \\
(1)\end{array}$ & $\begin{array}{l}\bar{x} \\
(1) \\
(1)\end{array}$ & $\begin{array}{l}\boldsymbol{x} \\
\boldsymbol{x} \\
\boldsymbol{x} \\
\bar{x} \\
\overline{0}\end{array}$ & 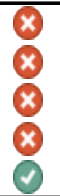 & $\begin{array}{l}\bar{x} \\
\dot{x} \\
\dot{x} \\
\dot{x} \\
\dot{\theta}\end{array}$ & $\begin{array}{l}x \\
\dot{x} \\
\dot{x} \\
\dot{x} \\
\end{array}$ \\
\hline$\stackrel{x}{(1)}$ & $\begin{array}{l}\text { Des } \\
\text { Tar } \\
\text { Tar }\end{array}$ & cluí & $\begin{array}{l}\text { difi } \\
\text { ac }\end{array}$ & & & & & & & \\
\hline
\end{tabular}

A fim de identificar quais tarefas são mais críticas e ser capaz de dar suporte a tomada de decisão caso recursos tenham de ser alocados para reparação de erros e dificuldades encontradas no teste, foi construída uma matriz GUT. As ocorrências foram sintetizadas no Apêndice 4.

\subsubsection{SUMI}

O método SUMI (Software Usability Measurement Inventory) é um rigoroso método para medição de qualidade, desenvolvido, validado e unificado em uma base internacional com diversos protótipos e softwares comerciais. Ele é utilizado para fazer comparação entre produtos ou versões de produtos e/ou identificar o software mais apropriado para a organização a partir da descoberta de falhas de usabilidade antes de um produto estar finalizado (SUMI). É importante frisar que este instrumento utiliza um banco de dados no qual são baseados os parâmetros de cada uma das escalas e este banco de dados é composto pelos mais variados tipos de software, incluindo sistemas comerciais com elevado custo de investimento financeiro e de recursos humanos em seu desenvolvimento.

Os itens do SUMI geralmente se referem à experiência que o respondente tem com o software sendo avaliado em comparação com suas expectativas. As expectativas surgem do trabalho com software de todas as variedades. Por exemplo, é raro que os entrevistados que avaliam um sistema tenham expectativas de experiência de muitos tipos diferentes de sistema. A maioria dos entrevistados estará comparando o sistema com o qual estão trabalhando, com 
outros softwares que eles usam em sua vida diária. Uma importante ressalva na análise do teste de usabilidade é que Nielsen (2000) aponta que com 5 usuários, aproximadamente $85 \%$ dos problemas de usabilidade são encontrados, porém no presente estudo, o instrumento de avaliação selecionado mostra-se bastante suscetível estatisticamente, o pode levar a interpretações imprecisas. Conforme mostra a Tabela 4, a instituição B pode ser considerada outlier para esta análise. O ideal seria aumentar o tamanho da amostra, contudo por conta de limitações de recursos disponíveis opta-se pela análise do instrumento com 4 dos 5 usuários, o que não significa que o usuário precisa ser desconsiderado do teste de usabilidade, visto que além da análise do instrumento, ainda existe o mapeamento de tarefas crtíticas e insights importantes advindos de outros momentos.

Tabela 4 - Pontuações das escalas avaliadas por instituição

\begin{tabular}{ccccccc}
\hline ID & Eficiência & Impacto & Assistência & Controle & Aprendizagem & Global \\
\hline C & 61 & 74 & 44 & 64 & 56 & 64 \\
A & 54 & 68 & 38 & 68 & 60 & 53 \\
D & 54 & 65 & 30 & 45 & 52 & 51 \\
E & 48 & 68 & 11 & 40 & 56 & 38 \\
B & 22 & 16 & 13 & 30 & 43 & 20 \\
\hline
\end{tabular}

As declarações apresentadas aos participantes abordam suas atitudes e sua relação com o sistema. O programa de software dedicado chamado SUMISCO, que integra o pacote de avaliação SUMI. A Tabela 5 traz um resumo das principais medidas estatísticas resultantes do SUMI.

Tabela 5 - Resumo estatístico do teste de usabilidade (SUMI)

\begin{tabular}{|c|c|c|c|c|c|c|}
\hline Escala & Descrição & Média & Desv-Pad & Mediana & Mín & Máx \\
\hline Global & $\begin{array}{l}\text { Sentimento geral de satisfação com } \\
\text { a experiência dos usuários do } \\
\text { software que está sendo avaliado }\end{array}$ & 51.50 & 10.66 & 52.0 & 38 & 64 \\
\hline Eficiência & $\begin{array}{l}\text { O software está permite a execução } \\
\text { das tarefas de maneira rápida, } \\
\text { eficaz e econômica }\end{array}$ & 54.25 & 5.32 & 54.0 & 48 & 61 \\
\hline Impacto & $\begin{array}{l}\text { A interação com o software } \\
\text { promove sensação agradável e é } \\
\text { estimulante }\end{array}$ & 68.75 & 3.77 & 68.0 & 65 & 74 \\
\hline Assistência & $\begin{array}{l}\text { O software se comunica de uma } \\
\text { maneira útil e auxilia na resolução } \\
\text { de problemas operacionais }\end{array}$ & 30.75 & 14.36 & 34.0 & 11 & 44 \\
\hline Controle & $\begin{array}{l}\text { o software está respondendo de } \\
\text { maneira esperada e consistente a } \\
\text { entradas e comandos }\end{array}$ & 54.25 & 13.82 & 54.5 & 40 & 68 \\
\hline Aprendizagem & $\begin{array}{l}\text { É relativamente simples } \\
\text { familiarizar-se com o software; e } \\
\text { que sua interface tutorial, manuais } \\
\text { são legíveis e instrutivos }\end{array}$ & 56.00 & 3.27 & 56.0 & 43 & 60 \\
\hline
\end{tabular}


É importante ressaltar que os resultados são pontuados e comparados com um banco de dados padronizado. A pontuação média do banco de dados padronizado é 50 , com um desvio padrão de 10. Como esse banco de dado é desenvolvido a partir de produtos comerciais bem-sucedidos, um sistema que atinge uma pontuação de 40 a 60 é comparável em termos de usabilidade à maioria desses produtos (o banco de dados de padronização inclui a pontuação abaixo e acima desse intervalo).

O banco de dados padronizado fornece, como uma diretriz geral, que um software comercial razoavelmente aceitável deve ter um conjunto de subpontuações de 55 ou mais, e uma pontuação global acima de 50 com um desvio padrão de 10 (com uma pontuação máxima de 73). Na escala global, a mais confiável de todas as escalas do SUMI indica que a usabilidade do sistema avaliado é comparável a sistemas comerciais bem-sucedidos, contudo a pontuação está abaixo da média. Em termos de usabilidade, as subescalas mostram que apenas a categoria Impacto obteve a pontuação razoavelmente aceitável, enquanto todas as demais apresentaram pontuações abaixo da média. É importante enfatizar a alarmante pontuação na categoria Assistência, quase trinta pontos abaixo do razoável.

A Figura 5 mostra a média para cada uma das categorias do SUMI e para a de Usabilidade Global. Se o valor de uma categoria estiver acima da linha 50 (ou seja, melhor que o banco de dados de referência), a barra será mostrada em verde. Se estiver abaixo da marca de 50 , a barra será mostrada em vermelho. As barras também mostram o intervalo do intervalo de confiança de $95 \%$ das médias usando os grampos verticais pretos. O significado deste conceito estatístico é o seguinte: se repetíssemos exatamente a mesma pesquisa, com o mesmo tamanho de amostra sob condições idênticas na mesma população de usuários (com seleção aleatória a cada vez) por um número infinito de vezes, os grampos mostram onde a média das amostras cairia $95 \%$ das vezes. Na prática, o que o intervalo de confiança de $95 \%$ nos diz é o intervalo de variação na amostra que está sendo analisada. 


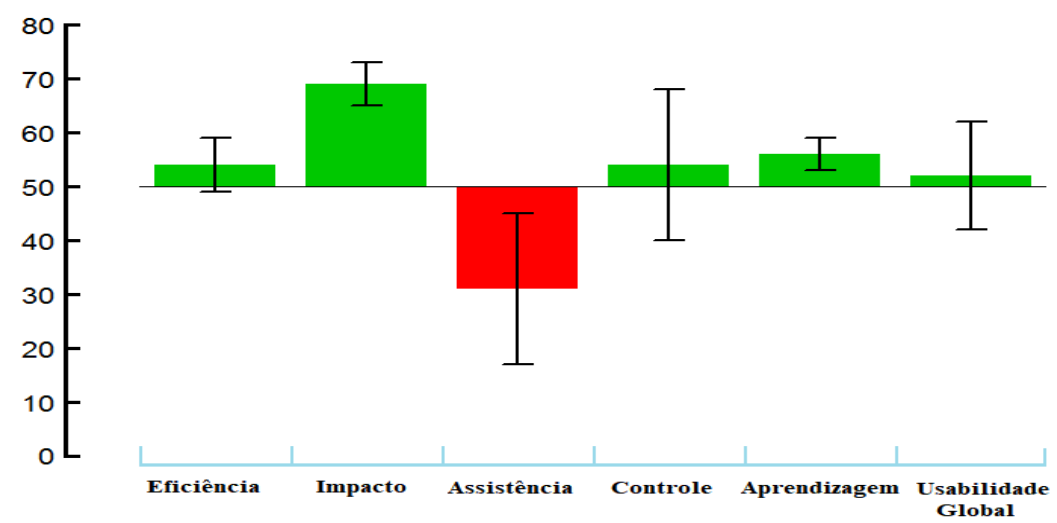

Figura 5 - Médias por escala SUMI com $95 \%$ de intervalo de confiança

Outra importante análise é a avaliação de pontos fortes e fracos do software quando comparado com as estatísticas no banco de dados padronizado. A maneira como seus respondentes responderam a cada pergunta é analisada e comparada de acordo com as chamadas frequências observadas e os resultados previstos pelo banco de dados (frequências esperadas). Existem três categorias de respostas para cada questão SUMI (Concordo - Não Sei - Discordo). A estatística Qui-Quadrado é usada como uma medida do grau em que as frequências observadas e esperadas diferem. Quanto maior o valor do QuiQuadrado, maior a diferença entre 'observado' e 'esperado'. O grau de liberdade utilizado é 2. Qualquer probabilidade maior ou igual a $p=0,95$ é tratada como 'estatisticamente significativas' (SUMI, 2019). Observa-se que há significância estatística quando há muitos mais votos "observados" do que "esperado". Se a afirmação for positiva, isso é um bom sinal. Se a afirmação é uma afirmação negativa, então isso é ruim. Um 'Discordo' de uma afirmação negativa é bom e 'Discordo' de uma afirmação positiva é ruim. O Quadro 9 mostra os pontos fortes e fracos com resultados estatísticos significantes.

Quadro 9 - Pontos fracos e fortes estatisticamente significantes

\begin{tabular}{|c|c|c|c|c|}
\hline Item & Afirmação & Veredito & $\mathbf{x}^{2}$ & $\begin{array}{c}\text { Valor } \\
\text { de } \mathbf{p}\end{array}$ \\
\hline 33 & A organização dos menus parece bastante lógica. & Discordo & 23,875 & 0,999 \\
\hline 13 & $\begin{array}{c}\text { A forma como as informações do sistema são } \\
\text { apresentadas é clara e compreensível. }\end{array}$ & Discordo & 18,854 & 0,999 \\
\hline 23 & $\begin{array}{c}\text { Eu posso entender e agir de acordo com as informações } \\
\text { fornecidas por este software. }\end{array}$ & Discordo & 18,608 & 0,999 \\
\hline 3 & As instruções e os prompts são úteis. & Discordo & 16,322 & 0,999 \\
\hline 28 & $\begin{array}{c}\text { O software me ajudou a superar os problemas que tive } \\
\text { ao usá-lo. }\end{array}$ & Discordo & 10,767 & 0,995 \\
\hline 15 & A documentação do software é muito informativa. & Discordo & 8,697 & 0,987 \\
\hline 4 & $\begin{array}{c}\text { Este software parou em algum momento } \\
\text { inesperadamente. }\end{array}$ & Discordo & 6,953 & 0,969 \\
\hline 8 & $\begin{array}{c}\text { Acho que as informações de ajuda fornecidas por este } \\
\text { software não são muito úteis. }\end{array}$ & Concordo & 6,126 & 0,953 \\
\hline
\end{tabular}


Observa-se que o único ponto positivo apresentado é o item 4, pode-se afirmar que durante o teste o software não parou inesperadamente. Os demais itens mostram-se de forma negativa e são fatores de atenção a serem levados em consideração na proposição de melhorias para o sistema.

Há ainda os resultados referentes aos demais itens, classificados como uma tendência dos respondentes a concordar, ou em discordar, ou ainda, a indiferença. Estes itens não serão tratados aqui pela baixa relevância estatística.

Além dos 50 itens com perguntas fechadas, são adicionadas 4 perguntas, sendo 2 delas abertas, a fim de compreender melhor a percepção subjetiva de cada usuário e ainda utilizar esses itens para realizar a triangulação dos dados a fim de corroborar ou contradizer resultados advindos das questões fechadas.

O item 51 do SUMI refere-se ao quão importante é o tipo de software para o usuário. Para dois deles é "Importante", para os outros três é "Extremamente Importante". Já o item 52 refere-se as habilidades e conhecimentos em software, $20 \%$ consideram-se experientes, mas não técnicos, $40 \%$ podem lidar com a maioria dos softwares, os outros $40 \%$ consideram-se muito experientes e técnicos.

Quando questionados sobre o melhor aspecto do software praticamente todos afirmam que a interface para o doador é o melhor aspecto, ainda que não tenham testado a aplicação para o doador diretamente, a apresentação do sistema abordou este viés. $O$ entrevistado $B$ afirma ainda que a concepção gerada para a resolução do problema é interessante. $O$ entrevistado $D$ afirma declara que o melhor aspecto é o maior controle e praticidade das operações. O entrevistado E afirma que o melhor aspecto além da interface, é a possibilidade de gerenciar diversas campanhas em um mesmo espaço.

O último item refere-se a sugestões de melhoria. O entrevistado $A$ identifica a necessidade de investimento em suporte, deu como sugestão direta a implementação de um "bot" para ligação com um canal de suporte técnico. O entrevistado $B$ sugere que sejam consideradas as melhores práticas do guia PMBOK no que tange aquisições, foi considerado um item de atenção pelo respondente. Outra sugestão é a consideração do universo de organizações do terceiro setor, segundo o respondente os termos são e vocabulários utilizados são muito técnicos e podem dificultar a utilização mais ampla do software. Já o entrevistado $C$ sugere a reorganização da forma de cadastro das informações, o ideal seria a utilização de abas, ou a utilização de um botão "Próximo" que deixasse o preenchimento mais lógico. Outro ponto sugerido foi a exportação de dados e relatórios ao longo dos processos. O entrevistado $\mathrm{D}$, assim como o $\mathrm{C}$, aponta a necessidade de exportar dados do sistema. Sugere ainda a possibilidade 
de agradecimento personalizado por campanha, manual das funcionalidades do sistema disponível, bem como um FAQ. Inserção do prazo de encerramento dos eventos e campanhas para o doador ter a visibilidade do quão perto do fechamento está. Assim como o entrevistado $\mathrm{C}$ as telas de cadastro são consideradas pouco intuitivas e não contínuas. Um fator apontado como limitante é a dependência de hospedagem para a aplicação.

Avaliando as respostas "livres" pode-se afirmar que os apontamentos feitos corroboram com os resultados apresentados nas questões fechadas. $O$ item com menor média foi o de "Assistência", que corresponde à percepção dos respondentes de que o software se comunica de maneira útil e auxilia na resolução de problemas operacionais. Essa baixa pontuação aliada a sugestão recorrente dos entrevistados indica que o software não está se comunicando adequadamente e pode dificultar tarefas de fácil execução.

\subsection{Análise frente às instituições de ajuda humanitária}

A aceitabilidade de um software proposta por Nielsen (1994) e composta pela aceitabilidade prática que consiste na avaliação de várias categorias tradicionais algumas já apresentadas na seção 4 a partir da RSL, como custos, compatibilidade etc. $O$ que se aprofunda com o estudo de caso realizado é a noção de aceitabilidade do sistema pelas instituições tendo como maior foco as categorias de utilidade e usabilidade, além da análise frente aos processos de doações e compras das instituições.

A chegada de itens não prioritários é uma realidade comprovadamente presente em todas as instituições segundo os resultados apresentados, problema recorrente em casos de desastres conforme destacam a Pan American Health Organization (2001), Holguín-Veras (2012), e Islam (2013), que também as entende como um obstáculo em contextos de assistência social. Todas as instituições aceitam estes itens ainda que não sejam necessários no momento, a fim de não prejudicar doações futuras. Outro ponto que pode estar associado a este fenômeno é o processo pouco estruturado e sem etapas bem definidas de doações e aquisições de recursos. Ainda impera a máxima do "o que vier é lucro", capaz de gerar transtornos exorbitantes já discutidos neste trabalho. Esses problemas têm reflexo direto nos custos logísticos seja em armazenagem, como na instituição $B, D$ e $E$ ou em recursos humanos e transporte (instituições $A, D$ e E), ratificando a relação entre o recebimento de itens não prioritários e o aumento dos custos logísticos estabelecida por Holguín-Veras (2012). 
Das 5 instituições, 3 afirmaram receber doações financeiras em maior quantidade, informação confirmada nos demonstrativos financeiros das instituições, em conformidade com o impulso crescente da comunidade internacional para esta forma de auxílio citado por Harvey e Bailey (2011), mas esta relativa superioridade que pode proporcionar maior flexibilidade para as organizações não indica uma garantia de atingimento da quantidade necessária para atendimento de determinada população. Por vezes, esses recursos são alocados em tarefas como transporte e armazenagem, que são encarecidos pelo recebimento de produtos inutilizáveis. Essa defasagem entre o que é necessário ou programado e o que é recebido ou executado poderia ter menor impacto nas ações das instituições caso estas investissem em programas educativos, ou outras formas de conscientização conforme Alexander (2013) enfatiza. Na prática, as instituições afirmam ter essa preocupação, mas limitam-se a divulgação de uma lista de itens que estão abertos a receber, em geral, nem mesmo com a quantidade necessária ou maiores especificações, o que poderia ser restruturado com o estabelecimento de um processo melhor definido. Para exemplificar, com exceção da instituição A nenhuma das demais afirma ter "Especificar recursos" em seu processo de aquisição, o que influi na assertividade e capacidade de tomada de decisão do doador, além de causar problemas em cascata durante as campanhas de arrecadação. E este fato poderia ser erroneamente atribuído, por desatenção, ao fato das instituições não apresentarem qualquer método de previsão de demanda, contudo isto ocorre pelo tipo de serviço prestado à população, que é de assistência social, como é o caso das instituições $B, C, D$ e $\mathrm{E}$ e consequentemente com um número bem definido de beneficiários e necessidades, ou pela natureza dos dados de caráter secundário, como é o caso da instituição $A$.

Nenhuma das instituições realiza avaliação, seja de doadores ou de fornecedores, perdendo oportunidade de fortalecer sua relação com dois stakeholders centrais de suas operações e executar ações direcionadas mais efetivas. O processo de gerenciamento de doações ocorre de maneira unânime entre todas as instituições com a utilização de planilhas eletrônicas, e somente a instituição $E$ afirma estar de fato insatisfeita com a forma atual de controle. O que não se reflete na reposta sobre o interesse da instituição no SmartDonation. Através do mapeamento das características dos processos e das respostas obtidas pode-se conjecturar que a utilidade do SmartDonation é identificada de maneira mais evidente por instituições que possuem pouca estruturação de processos, como a instituição C, D e E. Aquelas que possuem processos mais 
bem estruturados tendem a enxergar menor utilidade no sistema, ou apresentar maiores apreensões, sendo assim instituições que não possuem setor de compras ou processo bem estruturado mostram-se mais interessadas no sistema que pode cobrir uma deficiência da organização. Todas as organizações avaliaram positivamente a utilidade do sistema e todas, apesar das ressalvas, demonstraram interesse em utilizá-lo em suas operações.

Ao que se refere a usabilidade, o sistema apresentou uma série de oportunidades de melhoria. A primeira evidência é a quantidade de desistências ao longo das tarefas do teste de usabilidade, a maioria teve dificuldades de executar a tarefa 6 e somente um concluiu da 7 em diante, ainda que todos se autodeclarem usuários experientes. Os problemas de usabilidade ficam ainda mais evidentes na análise do SUMI, que ficou abaixo da média considerada aceitável, fato que pode ter sido ocasionado pelo pequeno tamanho da amostra, conforme demonstrado na seção anterior. Mesmo com a retirada do elemento outlier, o item "Assistência" é mal avaliado, que denota a baixa capacidade do sistema em auxiliar na resolução de problemas operacionais, é imediato conjecturar que caso este item estivesse melhor desenvolvido, talvez os demais itens pudessem ter um desempenho melhor, visto que ao se deparar com dificuldades durante o teste não havia módulo de ajuda ou manual disponível para consulta. Portanto, na categoria usabilidade, o SmartDonation fica abaixo do esperado no item "Assistência" e possui diversas melhorias a serem implementadas, a fim de diminuir o tempo necessário de treinamento e minimizar possíveis resistências na utilização do sistema, além de facilitar o acesso de usuários de vários níveis de expertise. 


\section{6 \\ Survey}

O presente capítulo apresenta o método survey utilizado para avaliação da aceitabilidade do sistema por potenciais doadores. O SmartDonation, a priori, depende da adesão de usuários externos à instituição para funcionar, já que se propõe a gerenciar doações financeiras e alocar os recursos provindo de doadores em compras para campanhas. Apesar de parecer relativamente simples não basta perguntar se um determinado usuário aceita ou não aceita determinada aplicação, mas se ao ser apresentado a esta aplicação o usuário corresponde de maneira satisfatória ao mesmo. Além da aceitabilidade social, são investigadas as atitudes, preferências e influência dos tipos de desastres na tomada de decisão dos doadores.

A aplicação do instrumento selecionado foi realizada entre os dias 21 de dezembro de 2018 a 30 de janeiro de 2019. A partir da coleta de dados obtida, é feita a análise da aceitabilidade do sistema e dos principais motivadores para doações e não-doações. O questionário que pode ser consultado no Apêndice 2.

\subsection{Resultados da estatística descritiva}

A fim de facilitar a análise dos resultados, as observações feitas a partir das respostas são divididas primeiramente por instrumentos de pesquisa, que são melhor detalhados no Apêndice 2.

O perfil e caracterização dos respondentes é baseado no instrumento $5 \mathrm{~A}$ e foi respondido integralmente por 94 pessoas e mostra que a média de idade é de 26,7 anos. Dos entrevistados $65,4 \%$ são do gênero feminino e $34,6 \%$ do gênero masculino; 75,5\% declara possuir Ensino Superior de escolaridade, 24,6\% Ensino Médio e menos de 1\% Ensino Fundamental. Em relação a renda familiar, 19,05\% afirmam possuir renda de até dois salários mínimos (valor de $\mathrm{R} \$ 998$ atualmente), $21,9 \%$ entre dois e quatro, $19,05 \%$ entre quatro e seis, $11,43 \%$ entre seis e oito, $8,57 \%$ entre oito e dez, $11,47 \%$ entre 10 e 15 e 8,57\% acima de 15 salários mínimos. Ao que se refere a denominação religiosa, mais da metade $(57,14 \%)$ dos entrevistados se identifica com denominações cristãs, desse total $47,62 \%$ são católicas, 9,52\% evangélicos; $33,33 \%$ não se identificam com qualquer 
denominação religiosa, $2,86 \%$ denominam-se espíritas e as demais denominações: adventismo, agnóstico, budismo, candomblé, politeísta, panteísta e crença numa divindade maior tem $0,95 \%$ dos respondentes cada.

A seguir é avaliada a inclinação em realizar diferentes tipos de doação em diferentes tipos de desastres a partir de uma escala likert de 5 pontos. É importante frisar que para fins de análise os respondentes são classificados de duas maneiras quanto a sua propensão de doar: caso tenham selecionado 4 ou 5 são considerados "Doadores", caso selecionem 3 são considerados "Neutros", e “Não Doadores" caso contrário. O instrumento 5B é respondido por 94 pessoas.

Conforme mostrado no Gráfico 2, há uma grande propensão dos respondentes em doar suprimentos, chegando a um percentual de Doadores ("Disposto" e "Muito disposto") superior a $80 \%$ em todos os tipos de desastres. É importante observar que o tipo de desastre com maior propensão a doação é a de início súbito e com causas naturais, com $90 \%$ dos respondentes dispostos ou muito dispostos a doar. Em casos de início lento há praticamente o mesmo percentual disposto a doar, independente da natureza da causa associada. Todavia ao se analisar conjuntamente com o percentual de não doadores observase que no caso de desastres de início lento e causas humanas há uma aversão à doação ligeiramente superior.

Gráfico 2 - Propensão à doação de suprimentos

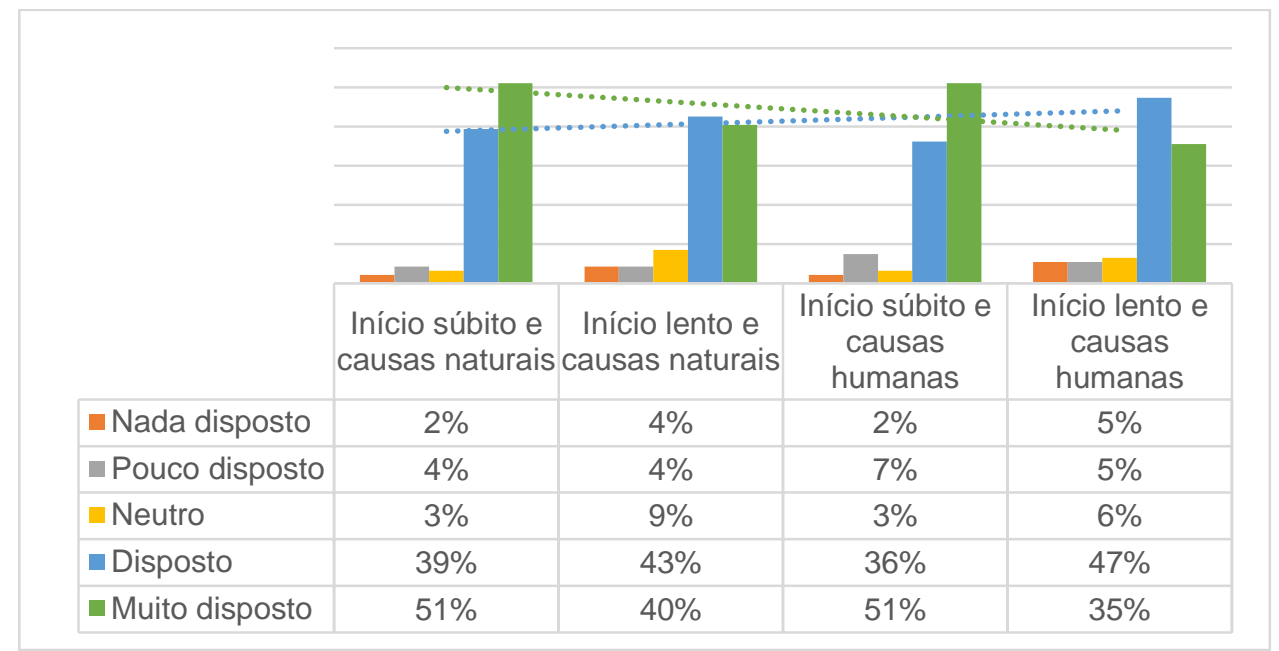

Em relação a doação de vestuário a grande propensão dos respondentes em doar permanece, chegando a um percentual de Doadores superior de $84 \%$ em 3 dos 4 tipos de desastres. Contudo, esse percentual diminui ligeiramente em desastres de início lento e causas naturais, chegando a 76\%. O percentual de não doadores se mantem entre 7 e $9 \%$ em todos os casos, conforme ilustrado no Gráfico 3. 


\section{Gráfico 3- Propensão à doação de vestuário}

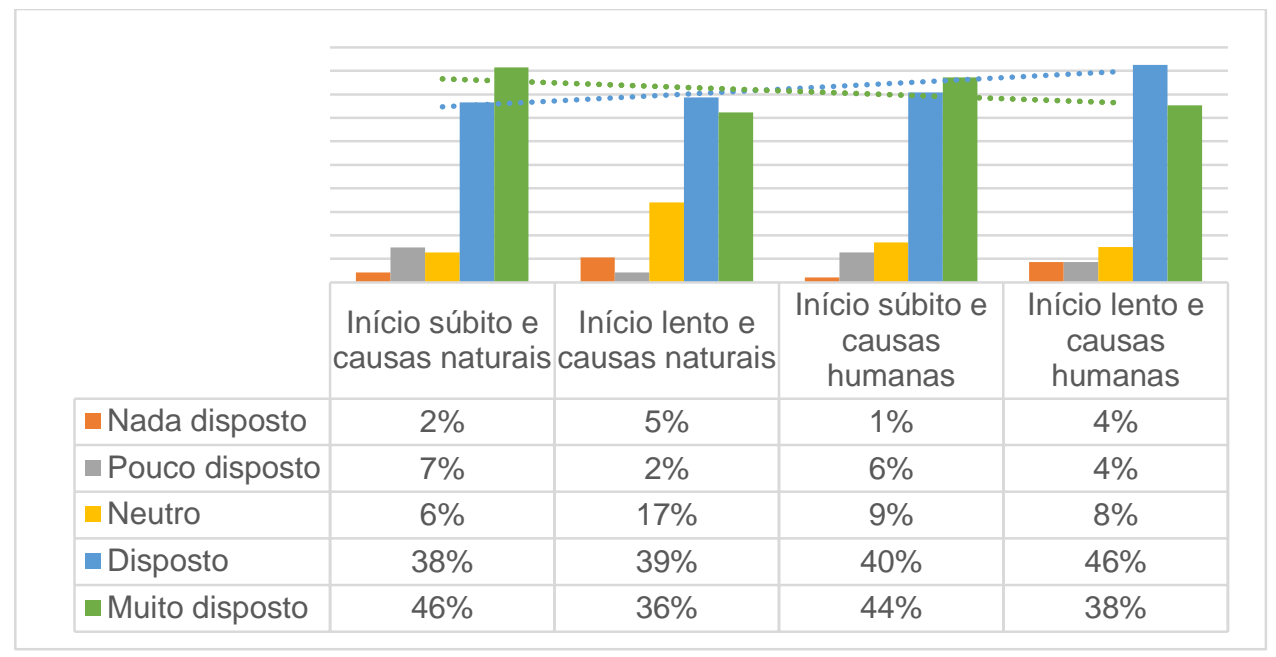

Já em relação a doação financeira o panorama muda drasticamente. Os respondentes mostram-se bem mais resistentes à doação em dinheiro que em relação aos demais tipos. O percentual de doadores por tipo de desastre varia entre 43 e 50\%, sendo o menor referente aos de início lento e causas humanas e o maior, aos de início súbito e causas naturais. Outra análise pertinente é relativa ao percentual de não doadores, os percentuais são elevados e variam entre $35 \mathrm{e}$ $39 \%$, que pode ser observado no Gráfico 4. Demonstrando que há a necessidade de um esforço para mudança de comportamento do doador, frente a este tipo de doação.

\section{Gráfico 4- Propensão à doação financeira}

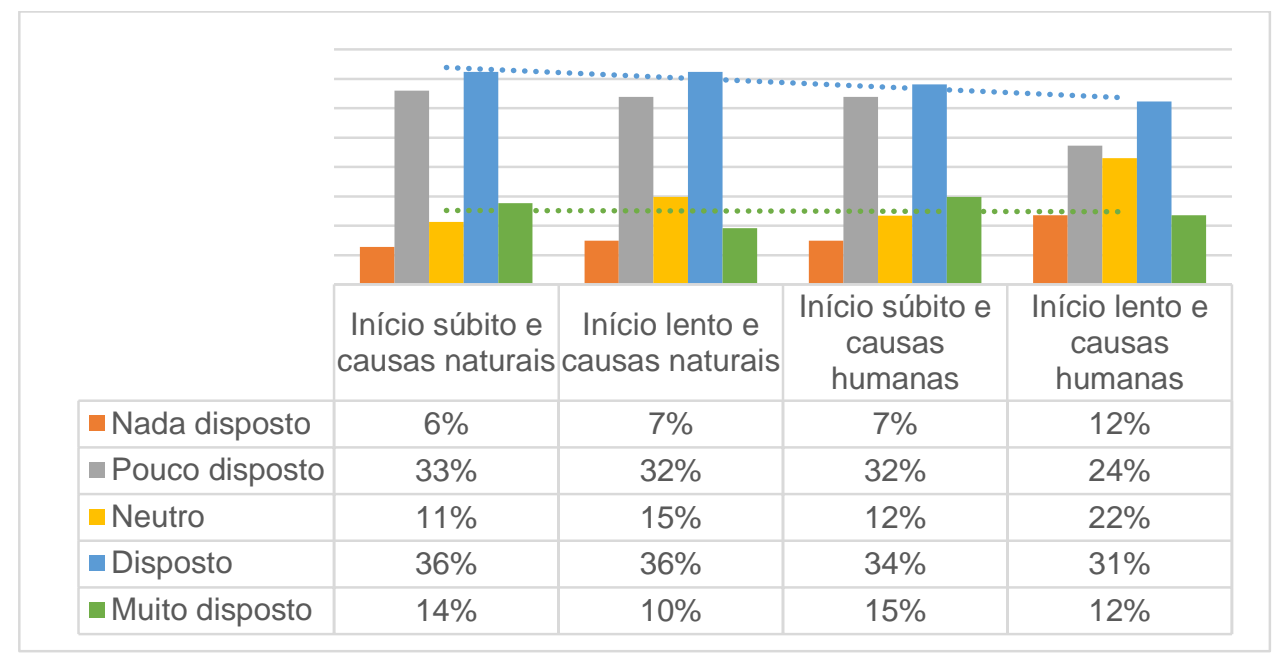

Pode-se observar uma maior inclinação a doação de itens, como suprimentos e vestuário, com uma tênue superioridade dos suprimentos. Esse resultado corrobora com o estudo de Holguín-Veras (2012) em que afirma que em muitos casos há grande volume de doações desse tipo. Apesar disso essa 
inclinação mostrada nos resultados contrasta com o levantamento da USP (2017) no qual há uma superioridade considerável de itens de vestuários e os suprimentos (alimentos) doados não chegam em quantidade suficiente. Essa maior inclinação a doação de itens materiais, aliada à resistência apresentada pelos respondentes em relação a doação financeira é o que na prática colabora para a ocorrência da convergência de materiais.

Já em relação a influência dos tipos de desastres na tomada de decisão, pode-se notar uma taxa menor de doadores em casos de desastres de início lento e causas humanas em dois dos três tipos de doações avaliadas. Por outro lado, quando se observa a maior taxa de doadores, corresponde aos casos de desastre de início súbito e causas naturais em todos os tipos de doações, seguido pelos desastres de início súbito e causas humanas. Essas informações provindas do instrumento 4B contrapõe o exposto por Zagefka et al. (2011), que afirmam que os desastres de causas naturais "provocam" mais doações em detrimentos dos de causas humanas, o que pode aferir é que, neste caso, a evolução mais rápida gera maior propensão à doação.

$\mathrm{O}$ instrumento $5 \mathrm{C}$ é respondido por 62 pessoas e equivale a compreensão dos motivos da não doação financeira, sendo pertinente entender as possíveis motivações que podem trazer importantes insights para as organizações e melhorias nos processos de captação de recursos. As respostas são múltiplas a fim de compreender se mais de um fator interfere no processo de decisão de não doar.

O principal motivo dado pelos respondentes é a de "Falta de recursos financeiros", que reforça os resultados das pesquisas realizadas pelo IDIS (2015, 2017). Nos dois anos o motivo citado como incentivo para realização de doações foi a "Falta de dinheiro" também sendo um dos fatores mais citados na pesquisa de da Costa, Daré e Veloso (2004), evidenciando que apesar do período de tempo decorrido entre as pesquisas a motivação principal se mantem. Este elemento não possui possibilidade de ação direta por parte das instituições, mas pode direcionar para um fracionamento e flexibilização das políticas de doação, já que o "Medo de se comprometer e não conseguir cumprir" também é um dos três motivos mais apontados como relevantes. Cabe frisar ainda a importância dada a aspectos relacionados à transparência, reformulação de estratégias de abordagem e divulgação contínua de ações destacados nas respectivas opções: "Não sei como o dinheiro será utilizado"; "Não confio em entidades sem fins lucrativos"; "Não gosto da forma que as entidades costumam abordar, acho muito invasivo"; "Não conheço os meios de ajuda e instituições". Essas informações consolidam o 
destaque feito por Alexander (2013) sobre a preocupação da comunidade de doadores sobre como o dinheiro é utilizado pelas organizações. Pode-se ainda ressaltar que a falta de exemplos ou hábitos pode ser relacionado a questões socioculturais que podem ser repensadas na lógica estratégica das organizações. Enfatiza-se que o processo de doação não foi considerado complicado por nenhum dos respondentes, o que pode ser um indicativo que a maneira de doar não é vista como um problema iminente.

O instrumento 5D corresponde a apresentação e avaliação da capacidade de o sistema tornar o respondente mais propenso a doação. O vídeo é indexado ao questionário no momento da coleta de dados, e apresenta os problemas inerentes as doações em geral, o funcionamento do sistema, bem como sua interface. Em seguida, as questões apresentadas no instrumento 5B são feitas novamente, a fim de avaliar se há mudança no comportamento dos respondentes. Este instrumento obteve 76 respostas, o que significa que 18 respondentes desistiram antes, logo as comparações nesta análise são feitas comparando as respostas desses mesmos respondentes ao instrumento 5B.

Cabe enfatizar que o percentual total de doadores tanto antes quanto após a apresentação do sistema é calculado com base nas respostas dadas apenas por aqueles que responderam a ambos, ou seja, apesar do instrumento 5B ter sido respondido por 94 pessoas, apenas as respostas do 76 que concluíram o instrumento 5D são levadas em consideração, por isso o percentual de doadores difere da análise feita anteriormente.

O Quadro 10 mostra a comparação das respostas dadas em relação à doação financeira através do Instrumento $5 \mathrm{~B}$, e as dadas no Instrumento $5 \mathrm{D}$, após a apresentação do SmartDonation. Percebe-se o decréscimo de Não doadores e Neutros em todos os tipos de desastres e consequente acréscimo no número de Doadores. Pode-se perceber que o número de doadores aumentou igualmente com 13 a mais em três dos tipos de desastres, com exceção aos de início lento e causas naturais que obteve 4 a menos, 9 a mais no total. Vale aqui ressaltar que o número de não doadores menor nos desastres de início lento não se traduzem em um número maior de doadores, o número de respondentes neutros nesses casos é maior, com destaque para a proporção considerável em casos de início lento e causas humanas.

Quadro 10 - Comparativo antes e após a apresentação do sistema

\begin{tabular}{|c|c|c|c|c|c|c|c|}
\hline \multicolumn{2}{|c|}{$\begin{array}{l}\text { Início súbito e } \\
\text { causas naturais }\end{array}$} & \multicolumn{2}{|c|}{$\begin{array}{c}\text { Início lento e } \\
\text { causas naturais }\end{array}$} & \multicolumn{2}{|c|}{$\begin{array}{c}\text { Início súbito e } \\
\text { causas humanas }\end{array}$} & \multicolumn{2}{|c|}{$\begin{array}{c}\text { Início lento e } \\
\text { causas humanas }\end{array}$} \\
\hline Antes & Depois & Antes & Depois & Antes & Depois & Antes & Depois \\
\hline
\end{tabular}




\begin{tabular}{|c|c|c|c|c|c|c|c|c|}
$\begin{array}{c}\text { Não } \\
\text { doadores }\end{array}$ & 29 & 18 & 26 & 19 & 29 & 18 & 25 & 18 \\
\hline Neutros & 8 & 6 & 12 & 10 & 9 & 7 & 17 & 11 \\
\hline Doadores & 39 & 52 & 38 & 47 & 38 & 51 & 34 & 47 \\
\hline
\end{tabular}

A fim de melhor ilustrar essa variação, o Gráfico 5 mostra os percentuais relacionados a quantidade de doadores antes e após a apresentação do sistema.

Gráfico 5 - Classificação antes e após a apresentação do sistema

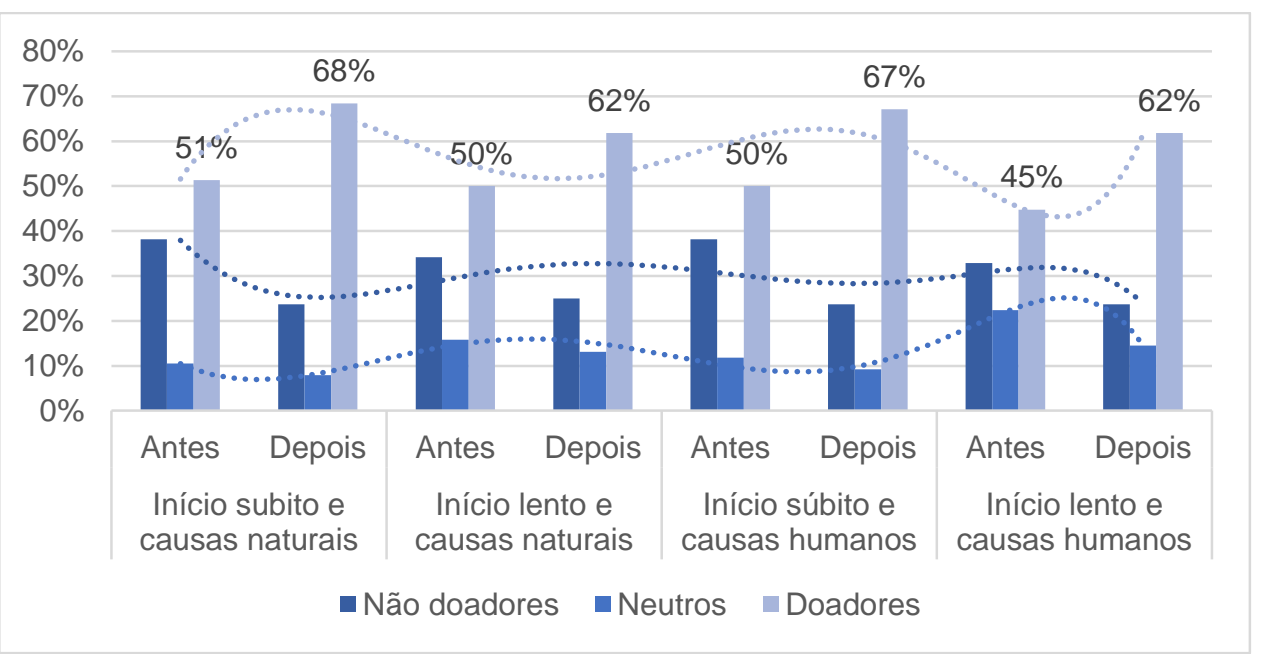

Apesar de visualizar o percentual de queda, manutenção e aumento em cada classificação dos tipos de doadores, não é possível afirmar o percentual de mudança, ou seja, qual porcentagem de "Não doadores" se manteve assim, tornou-se "Neutro" ou "Doador" e vice-versa. O Gráfico 6 traz essa informação levando em consideração os desastres de início súbito e causas naturais, mostrando de forma mais detalhada como os respondentes de fato reagiram após a apresentação do sistema. O eixo vertical refere-se à classificação anterior dos respondentes, enquanto o eixo horizontal ilustra o percentual de cada classificação posterior a apresentação do sistema. Observa-se que os respondentes caracterizados como "Inicialmente doadores" mantiveram sua propensão, em sua maioria. Aqui é mais facilmente observado que apesar do número maior de Não Doadores "convertidos" em Doadores, a taxa dessa conversão dos Neutros em Doadores é maior, evidenciando a já esperada dificuldade em mudar o comportamento do doador avesso à doação financeira. 
Gráfico 6 - Respondentes (início súbito e causa natural)

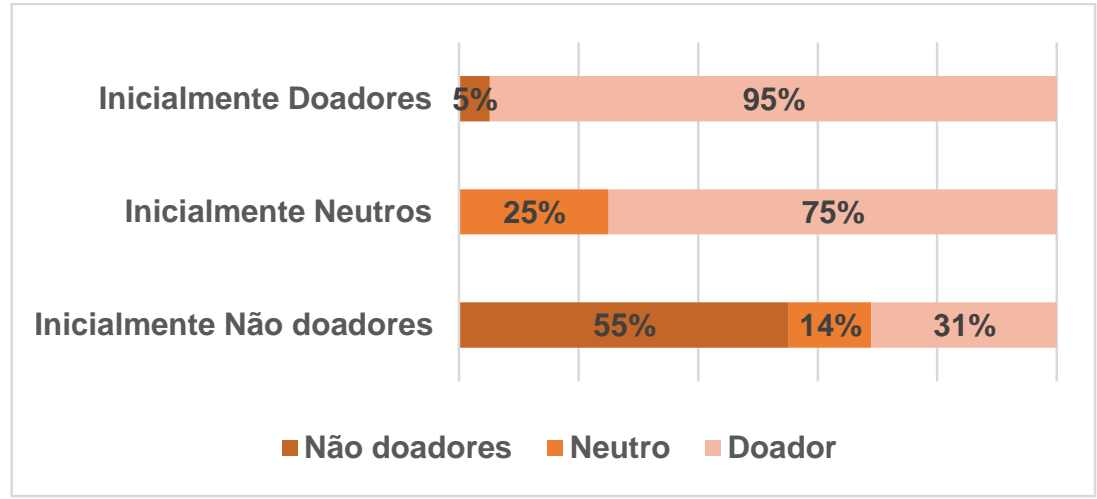

O Gráfico 7 mostra o percentual de manutenção e mudança dos respondentes quanto a sua classificação em casos de desastres de início lento e causas naturais. O comportamento dos Inicialmente Doadores e Inicialmente Não Doadores seguiu o mesmo padrão do caso anterior com taxas de migração e manutenção de comportamento muito próximas dos valores anteriormente mencionados, enquanto os Neutros se tornaram mais propensos a doar em uma taxa muito menor, além de uma parte ter se tornado avesso à doação, o que não ocorreu no caso anterior, podendo ser um indicativo que a velocidade da evolução do desastre pode ter um maior peso na tomada de decisão.

Gráfico 7 - Respondentes (início lento e causa natural)

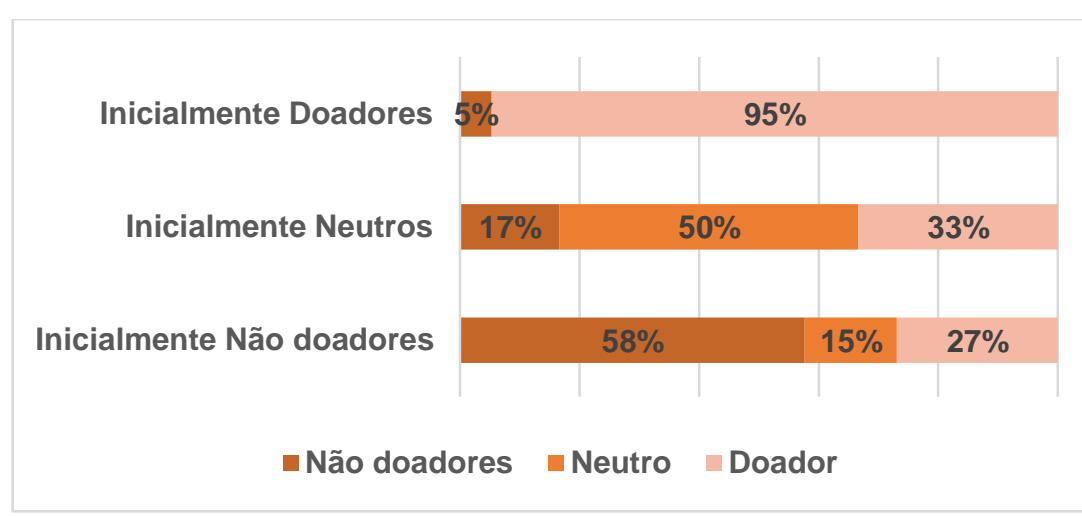

O Gráfico 8 mostra o percentual de manutenção e mudança dos respondentes quanto a sua classificação em casos de desastres de início súbito e causas humanas. O comportamento dos Doadores também se manteve praticamente o mesmo dos casos anteriores com uma menor taxa de aversão ao sistema detectada (3\%), e a taxa de mudança e manutenção de Não Doadores é exatamente a mesma dos desastres de início súbito e causas naturais. Ao observar os Neutros percebe-se uma mudança mais relevante em relação aos casos anteriores, mais da metade do total mostrou-se mais propenso a doar, 
enquanto 33\% se manteve neutro, ou seja, o sistema não foi causou uma menor ou maior propensão para doação, não interferindo na tomada de decisão. Os $11 \%$ restantes até então neutros não doariam através do sistema.

\section{Gráfico 8 - Respondentes (início súbito e causa humana)}

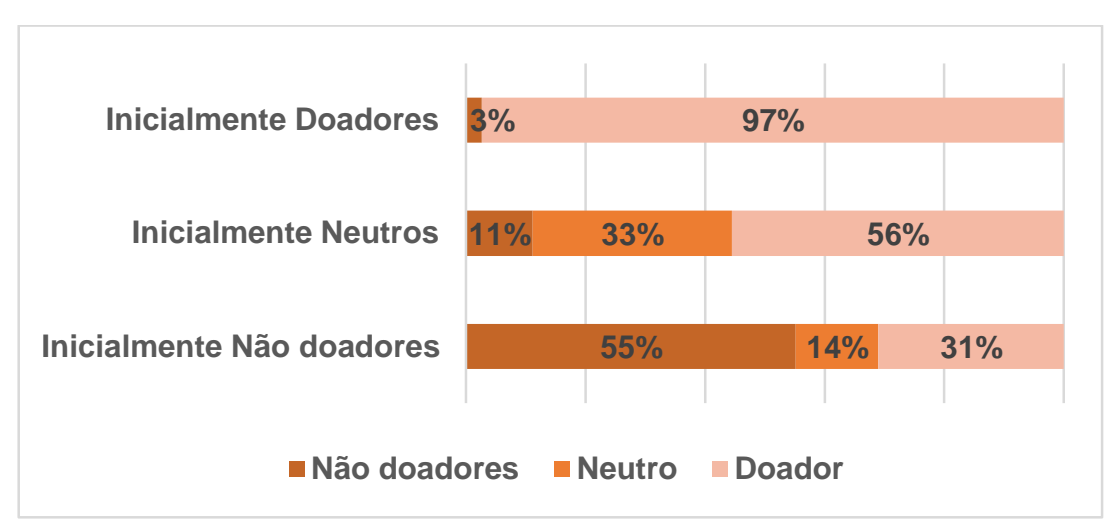

O Gráfico 9 mostra a mudança de manutenção de status dos respondentes em casos de desastres de início lento e causas humanas. As taxas de manutenção e mudança de Doadores permanecem muito similar aos casos anteriores. A taxa de conversão de Neutros em Doadores chega a 53\% assemelhando-se ao caso anterior (início súbito e causas humanas) e o percentual que se mantem neutro é de cerca de $41 \%$. A maior diferença, no entanto, se dá ao se observar os Não Doadores, a taxa de manutenção desse status é de 64\%, a maior entre todos os tipos de desastres e a taxa de mudança para Doadores é a menor, cerca de $20 \%$ do total, mostrando que pode haver uma percepção diferente pelos respondentes com este tipo de desastre que ocasiona uma maior resistência à doação. 
Gráfico 9 - Respondentes (início lento e causa humana)

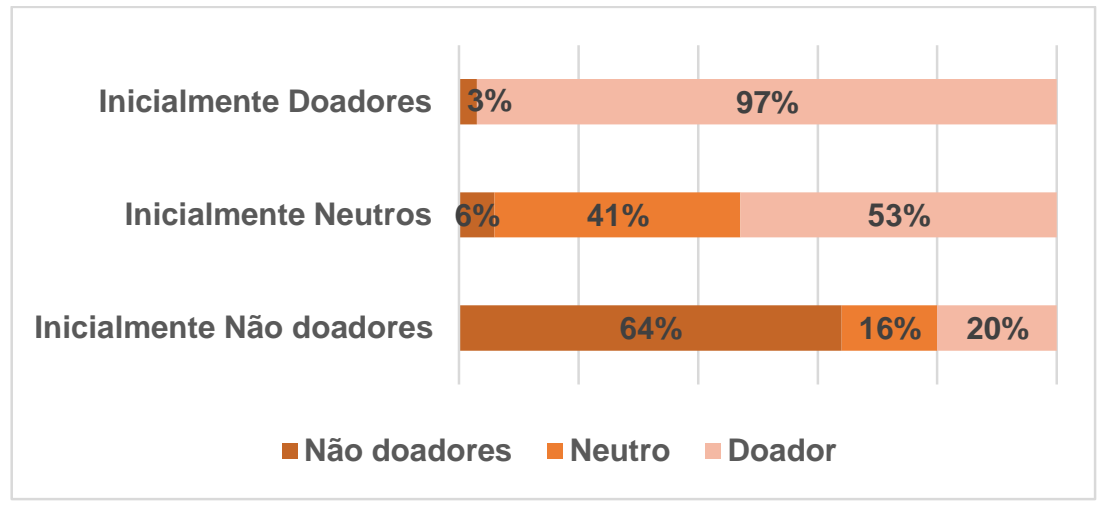

Cabe enfatizar que nos gráficos anteriormente ilustrados, a porcentagem refere-se ao total daquela classificação, contudo é relevante apontar a porcentagem do total de respondentes que migra de classificação de maneira "positiva", ou seja, apresenta maior propensão à doação financeira. Observa-se que em casos de desastres de início súbito e causas naturais, 5\% do total de 76 respondentes eram Inicialmente Não doadores e se tornaram Neutros, 8\% de Neutros tornaram-se Doadores e 12\% dos Não Doadores tornaram-se Doadores. Esse e os demais casos são ilustrados no Quadro 11, onde ND são Não Doadores; $\mathrm{N}$, Neutros e D, doadores.

Quadro 11 - Taxa de migração positiva por tipo de desastre

\begin{tabular}{|l|c|c|c|c|}
\cline { 2 - 5 } \multicolumn{1}{c|}{} & ND $\neg \mathbf{N}$ & $\mathbf{N} \neg \mathbf{D}$ & ND $\neg \mathbf{D}$ & Migração positiva \\
\hline Início súbito e causas naturais & $5 \%$ & $8 \%$ & $12 \%$ & $25 \%$ \\
\hline Início lento e causas naturais & $5 \%$ & $5 \%$ & $9 \%$ & $19 \%$ \\
\hline Início súbito e causas humanas & $5 \%$ & $7 \%$ & $12 \%$ & $24 \%$ \\
\hline Início lento e causas humanas & $5 \%$ & $12 \%$ & $7 \%$ & $24 \%$ \\
\hline
\end{tabular}

Ressalta-se que os resultados obtidos instrumento 5D corroboram parcialmente com a afirmação de Zagefka et al. (2011) sobre haver maior propensão de doações em desastres causados naturalmente. Foi possível observar que em desastres de início súbito e causas naturais os respondentes demonstram maior propensão a doação, bem como menor resistência à mudança, contudo desastres de causas naturais, mas com início lento não é possível fazer as mesmas afirmações. $O$ instrumento $5 \mathrm{E}$ também foi analisado, porém por se tratar de fatores gerais de influência e preferências nas doações, e não-exclusivos ao SmartDonation optou-se por apresenta-lo no Apêndice 5. 


\subsection{Análise do SmarDonation frente à percepção de doadores}

Esta seção é dedicada à análise do sistema frente aos resultados descritos na seção anterior em associação aos constructos propostos na seção 3.4.

O primeiro fator relacionado é a influência dos tipos de desastres na tomada de decisão do doador. Nos resultados obtidos os desastres de início súbito e causas naturais geram maior inclinação a doações de todos os tipos que os demais tipos de desastres, que corrobora com o estudo realizado por Zagefka et al. (2011) que indica maior inclinação a doação em desastres associados a causas naturais. Todavia, essa afirmação não se confirma para os casos de desastres naturais de início lento, que em nenhum dos três tipos de doação (suprimentos, vestuário ou doação financeira) apresenta maior inclinação à doação pelos respondentes ao ser comparados com os casos de início súbito e causas humanas, por exemplo. A propensão à doação, neste caso, só se mostra maior que em desastres de início lento e de causas humanas em caso de doações financeiras. O que chamamos de taxa de migração de classificação dos respondentes foi mais significativa em desastres de início súbito e a que apresentou pior desempenho refletido em altas taxa de manutenção do status anterior refere-se aos desastres de início lento e causas humanas. Esses resultados, obtidos através do instrumento $5 \mathrm{~B}$ e $5 \mathrm{D}$, levam a supor que a velocidade de evolução do desastre possui maior influência que a origem do mesmo.

O segundo fator refere-se à motivação que compreende uma série de elementos envolvidos no estimulo ou desestimulo do ato de doar. Como principais motivações para não doar são citados elementos individuais, o principal apontado é a falta de recursos financeiros (44\%), resultado consonante com as pesquisas do IDIS $(2015 ; 2017)$. Ainda aparecem elementos externos ligados as entidades, sendo a incerteza em como os recursos são utilizados (34\%), o principal apontado, apontado por Alexander (2013) como o principal entrave a doações financeiras. Já em relação aos principais elementos relacionados ao ato de doar são citados elementos altruístas, como preocupação social (67\%), e pessoais, como identificação com a organização (49\%) e satisfação interna gerada (41\%). A importância de elementos para avaliação de uma instituição também é discutida assim como na pesquisa de da Costa, Daré e Veloso (2004). A transparência e controle foram os principais elementos apontados pelos respondentes. Quando o assunto são as ferramentas determinantes na busca de informações e solicitação de doações, há uma superioridade significativa das redes sociais (88\%), seguida 
por TV (65\%) e campanhas publicitárias (48\%). A importância crescente das redes sociais pode ser percebida ao comparar os resultados da PDB (IDIS, 2015) em que $48 \%$ citaram as redes sociais como ferramenta determinante para doações financeiras.

O terceiro fator referente as preferências se justificam a partir da necessidade de entender quais das citadas pelos respondentes podem ser implementadas ou melhoradas pela instituição. Pode-se perceber novamente a influência das redes e mídias sociais para os doadores que aparece como forma preferencial para acompanhar as realizações a partir das doações $(75 \%)$, seguido por e-mails informativos enviados (65\%), e divulgação no site da própria instituição (60\%). Além da indicação de preferência por várias possibilidades na forma de doar, e predileção por divulgação de auditorias do tipo externa que é considera confiável ou muito confiável por $98 \%$ dos respondentes.

Diante dos resultados apresentados na seção anterior, pode-se afirmar que o software é visto positivamente por parte considerável dos respondentes. Dos 76 respondentes, pelo menos 52 doariam financeiramente através do sistema em alguma das situações apresentadas. Vale ressaltar que a taxa de migração também é um dado importante, visto que demonstra a possibilidade de mudança no comportamento do não doador e do respondente neutro, chegando a $25 \% \mathrm{em}$ um dos casos. Obviamente, sabe-se que a propensão à doação financeira pode não se concretizar e um aumento de $17 \%$ no número dos respondentes classificados como "Doadores" não significa que o sistema é capaz de aumentar a taxa de doação das instituições em 17\%, mas significa que o entorno social se vê afetado positivamente com o sistema e, portanto, pode ser considerado aceito por parte dos potenciais doadores. 


\section{7 \\ Conclusão}

Com a aplicação da pesquisa, pode-se afirmar que os objetivos do estudo foram alcançados, visto que é possível avaliar o atendimento do SmartDonation às funcionalidades esperadas de um sistema de gerenciamento em operações humanitárias e a aceitabilidade do sistema pelas instituições e potenciais doadores, respondendo às questões de pesquisa apresentadas. Também é possível identificar as principais ferramentas utilizadas no gerenciamento de doações; caracterizar os processos de doações e compras das instituições; investigar a propensão de doação financeira pelos usuários diante do sistema, bem como os fatores que influem no ato de doar ou não, bem como suas preferências, atingindo, portanto, os objetivos secundários do estudo.

O referencial teórico elucidou os principais problemas envolvendo doações materiais, evidenciando os benefícios que a doação monetária pode trazer, além das questões envolvidas no processo decisório do doador. Também reforçou a importância do processo de compras e suas principais etapas envolvidas, e as principais formas de avaliação de software, reforçando a necessidade de avaliar protótipos e sistemas teoricamente finalizados, além de evidenciar lacunas e oportunidades de pesquisa no uso de softwares em LH.

A aplicação dos três métodos de pesquisa foi complementar e permitiu o melhor entendimento da percepção de vários stakeholders, e melhor entendimento das questões relacionadas a cada um deles. A RSL permitiu identificar as principais funcionalidades e características dos sistemas de gerenciamento em LH, identificar as ferramentas já propostas, desenvolvidas e/ou já utilizadas em LH e compará-las com o objeto de estudo com base nas funcionalidades identificadas, sendo relevante para melhorias e melhor atendimento dos requisitos do público-alvo do sistema com base na literatura, bem como estabelecimento do estado da arte de sistemas utilizados em gerenciamento de doações em operações humanitárias. Além disso, a RSL comprovou uma quantidade relativamente pequena de ferramentas que cobrem as funcionalidades propostas e o alcance restrito das mesmas, também foi possível identificar elementos de aceitabilidade prática, como custos e compatibilidade. 
Já o estudo de caso foi capaz de analisar como as instituições operam e avaliar sua aceitabilidade, além de avaliar mais profundamente sua usabilidade. Como resultado, identificou-se problemas urgentes a serem solucionados, como no cadastro de produtos e atualização de índices de consumo, que gerariam consequências graves na utilização em campo; necessidade de geração de relatórios; confirmação de ações pelo usuário antes da execução das mesmas, entre outros insights alcançados pelas instituições que testaram a ferramenta. $\mathrm{O}$ estudo de caso ainda foi capaz de evidenciar os pontos fracos no que tange a usabilidade do sistema, considerado insuficiente em Assistência, mesmo sem a exclusão do elemento considerado outlier. Ademais as instituições puderam demonstrar que apesar das arestas a serem retificadas na usabilidade, o sistema é útil, principalmente para instituições que possuem a aquisição de recursos em seu escopo de funcionamento, mas que ainda necessitam de estruturação e suporte tecnológico. Foi possível ainda o cruzamento das informações coletadas durante as entrevistas com informações disponibilizadas pela própria instituição, identificando características dos processos de cada uma das instituições, similaridades como o uso unânime de planilhas eletrônicas com pouca ou nenhuma automação dos processos, e política de recebimento de itens não prioritários, que comprometem a eficiência e eficácia dos processos da organização. Também foi possível coletar sugestões de melhorias diretamente com as organizações que o sistema visa atender. O estudo de caso, portanto, comprovou a aceitabilidade do sistema por parte das instituições, contudo também apontou a necessidade de melhorias para um bom funcionamento.

A pesquisa survey foi capaz de avaliar a aceitabilidade do sistema, e analisar as atitudes, preferências e motivações dos doadores concomitantemente. Como resultado, identificou-se que a inclinação a doação de suprimentos e vestuário é consideravelmente maior que a financeira. Foi possível constatar que os tipos de desastres que geram maior propensão a doações são os de início súbito e causas naturais, e que neste estudo a velocidade de evolução dos desastres tem maior peso para os respondentes que a origem. Foi possível comprovar a capacidade do sistema em mudar positivamente a inclinação do usuário a doações financeiras, podendo chegar a $25 \%$. A pesquisa ainda identificou que o principal fator relativo a não doação é de caráter individual (falta de recursos) e não externo, a preocupação social e autossatisfação gerada aliadas à transparência e técnicas de captação de recursos apropriadas são os principais motivos para doação. Além das preferências relatadas pelos usuários e o valor típico (mediana) de doações que estariam dispostos a fazer que foi de $R \$ 247,50$ ao ano. A pesquisa foi, 
portanto, capaz de validar a aceitabilidade do sistema pelos potenciais doadores e entender os fatores relevantes na tomada de decisão.

Dentre as limitações presentes no decorrer da pesquisa, pode-se citar a ausência de estudo quantitativo das funcionalidades das ferramentas encontradas na RSL, dessa forma a análise não se resumiria a avaliar de as ferramentas apresentam determinada funcionalidade, mas o grau de impacto dela no sistema e o quão melhor uma funcionalidade é melhor em um sistema que em outro. Outra limitação é o tamanho da amostra utilizada no teste de usabilidade do estudo de caso, que é a mínima recomendada, e mostrou-se muito suscetível a interferência de outliers. A ausência de análises estatísticas mais robustas, como análise fatorial, são uma limitação significativa da pesquisa survey, bem como o tamanho da amostra que ao final do questionário, no Instrumento 4E obteve apenas 52 respostas, menos de $50 \%$ dos respondentes iniciais. Outra limitação da pesquisa survey é a definição da amostra que foi feita por conveniência, que limita a generalização da pesquisa. Além das já citadas outro fator limitante é a realização do teste de usabilidade por apenas um dos stakeholders envolvidos nas operações. Outra limitação é que apenas as instituições tiveram contato direto como sistema desenvolvido, os doadores apenas visualizaram sua interface e tiveram uma explanação sobre a problemática que o mesmo visa minimizar.

Contudo, apesar das limitações expostas, o presente estudo apresenta diferentes contribuições de forma efetiva com implicações teóricas e práticas. Em relação às implicações teóricas, há uma contribuição para a literatura de gestão de operações humanitárias, experiência do usuário (UX) e marketing social, visto que foram discutidas a relação entre ferramentas desenvolvidas e utilizadas em LH, a percepção dos usuários frente ao sistema desenvolvido, além de investigar os fatores relevantes na tomada de decisão de doadores que podem ser influenciados por campanhas de marketing. Quanto às implicações práticas, esta pesquisa contribui para a entendimento das possibilidades de melhorias do objeto de estudo a partir da perspectiva direta de stakeholders envolvidos nas ações nas quais o sistema busca dar suporte. Ressalta ainda necessidade da busca por estratégias focadas na transparência por parte das instituições, investimento nos pontos indicados como principais pelos usuários, além da necessidade de ferramentas complementares para orientação de doadores.

Salvo os aspectos mencionados como resoluções necessárias ou proposições de melhorias, as instituições podem encontrar no SmartDonation o atendimento a uma lacuna operacional ao passo que os doadores encontram no layout similar ao de uma loja virtual maior transparência e familiaridade no ato de 
doar, trazendo, dessa forma, melhorias significativas nas operações humanitárias e de assistência social. Em relação às limitações referentes aos métodos de pesquisa, sugere-se como trabalhos futuros que na RSL seja realizada a análise quantitativa das funcionalidades e não apenas descritiva, bem como a atualização da revisão realizadas em outras bases além do Scopus. Apesar do tamanho da amostra utilizada no estudo de caso ter sido apresentado como limitação para o instrumento de análise (SUMI), não se sugere a realização do estudo em uma amostra maior, visto que os insights são considerados suficientes para implementação de melhorias. O que se sugere então é o acompanhamento da utilização do sistema em situações reais ou em simulações de campo, após a resolução dos problemas encontrados e implementação de melhorias. Sugere-se também a utilização de análise fatorial a fim de dar maior robustez estatística para os resultados. Além disso, pode-se investigar ainda a propensão de doações por parte de potenciais doadores em diferentes sistemas já desenvolvidos em compará-los quanto à eficácia. 
8

\section{Referências}

ABNT - ASSOCIAÇÃO BRASILEIRA DE NORMAS TÉCNICAS. (2003). NBR ISO/IEC 9126-1: Engenharia de software: qualidade de produto: Parte 1: Modelo de qualidade.

ABNT - ASSOCIAÇÃO BRASILEIRA DE NORMAS TÉCNICAS. (2011). NBR ISO 9241-11: Requisitos ergonômicos para o trabalho com dispositivos de interação visual: Parte 11: Orientações sobre usabilidade

ABRAN, A.; KHELIFI, A.; SURYN, W.; SEFFAH, A. (2003). Usability meanings and interpretations in ISO standards. Software quality journal, 11(4), 325-338.

AGRAWAL, R., SPRINGER, A., \& LOVELL, E. (2015, October). QuickResponseHost: Enabling crowdsourced disaster response stations. In 2015 IEEE Global Humanitarian Technology Conference (GHTC) (pp. 233-239). IEEE.

AHMED, Z., YASMIN, S., \& IMTIAZ, A. (2014, April). Helping Hand: An efficient donation procedure based on mobile banking. In 2014 International Conference on Electrical Engineering and Information \& Communication Technology (pp. 1-5). IEEE.

AIDMATRIX. Strategies and Solutions. Disponível em <http://www.aidmatrix.org/>. Acesso em: 16 out. 2018

AKHTAR, P.; MARR, N.E.; GARNEVSKA, E.V. (2012), "Coordination in humanitarian relief chains: chain coordinators", Journal of Humanitarian Logistics and Supply Chain Management, Vol. 2 No. 1, pp. 85-103

ALEXANDER, J. (2013), "Don't get upset when relief organizations use your donations for overhead", Slate Magazine, 14 de Novembro. Disponível em https://slate.com/news-and-politics/2013/11/how-typhoon-aid-organizationsspend-your-cash-donations.html. Acesso em:: 25 nov. 2018

ALMEIDA, L. R. D. (2016). Acessibilidade virtual: um estudo sobre a acessibilidade, a usabilidade e a comunicabilidade em portais institucionais federais.

ALVES, M. D. L. (2016). Análise e projeto de usabilidade com o redesign do sistema de ambulatório e faturamento do hu-ufsc.

ARNETTE, A. N.; ZOBEL, C. W. (2016). Investigation of material convergence in the September 2013 Colorado floods. Natural Hazards Review, 17(2), 05016001.

ASSILA, A.; EZZEDINE, H. (2016). Standardized usability questionnaires: Features and quality focus. Electronic Journal of Computer Science and Information Technology: eJCIST, 6(1). 
AVILA, J.; SOSTMANN, K.; BRECKWOLDT, J.; PETERS, H. (2016). Evaluation of the free, open source software WordPress as electronic portfolio system in undergraduate medical education. BMC medical education, 16(1), 157.

BACIGALUPE, G.; VELASCO-MARTIN, J. (2018, March). Are Crisis Platforms Supporting Citizen Participation?. In International Workshop on Complex Networks (pp. 283-290). Springer, Cham.

BACKER, P. D.; COSTA, H. M. (1995). Gestao ambiental. A administracao verde. Rio de Janeiro. Qualitymark.

BEHL, A.; DUTTA, P. (2018). Humanitarian supply chain management: a thematic literature review and future directions of research. Annals of Operations Research, 1-44.

BELOW, R.; WALLEMACQ, P. (2018). Annual disaster statistical review 2017. Centre for Research on the Epidemiology of Disasters (CRED).

BERK, L.; BERK, M.; DODD, S.; KELLY, C.; CVETKOVSKI, S.; JORM, A. F. (2013). Evaluation of the acceptability and usefulness of an information website for caregivers of people with bipolar disorder. BMC Medicine, 11(1), 162.

BICKMAN, L.; ROG, D. J. (1998). Handbook of applied social research methods. British Journal of Educational Studies, 46, 351-351.

BLECKEN, A. (2009). A reference task model for supply chain processes of humanitarian organizations. Universität Paderborn, Alemanha.

BLECKEN, A. (2010). Supply chain process modelling for humanitarian organizations. International Journal of Physical Distribution ; Logistics Management, 40(8/9), 675-692.

BRICK, J. M.; KALTON, G. (1996). Handling missing data in survey research. Statistical methods in medical research, 5(3), 215-238.

CAREEM, M.; SILVA C.; SILVA R.; RASCHID L.; WEERAWARANA S. Sahana: Overview of a Disaster Management System. International Conference on Information and Automation,Colombo, Sri Lanka, 2006

Carneiro, P. V.; Costa, O. A. F.; Brito Jr, I.; Yoshizaki, H. T. Y. (2014). Uma análise sobre o pós-desastre das chuvas em Cubatão ocorridas em fevereiro de 2013. In Anais do XXVII ANPET-Congresso Nacional de Pesquisa e Ensino em Transporte.

CAUCHICK, P.; MORABITO, R., ; PUREZA, V. (2011). Metodologia de pesquisa em engenharia de produção. Elsevier Brasil.

CENTRE OF RESEARCH FOR THE EPIDEMIOLOGY OF DISASTERS (CRED). International Disaster Database 2018. Disponível em: http://www.emdat.be/. Acesso em: 25 jun. 2018.

CERTO, S. T.; DAILY, C. M.; CANNELLA JR, A. A.; DALTON, D. R. (2003). Giving money to get money: How CEO stock options and CEO equity enhance IPO valuations. Academy of Management Journal, 46(5), 643-653. 
CHIKOLO, I. (2006). Role of logistics in humanitarian relief operation. CILT World, 14(7), 7.

CHOMILIER, B.; SAMII, R.; VAN WASSENHOVE, L.N. (2003), "The central role of supply chain management at IFRC", Forced Migration Review, Vol. 18 No. 2, pp. 15-16

COETZEE, C.; VAN NIEKERK, D. (2012). Tracking the evolution of the disaster management cycle: A general system theory approach. Jàmbá: Journal of Disaster Risk Studies, 4(1), 1-9.

COSTA, R. (2017). Arquitetura Da Informação E Usabilidade Em Interfaces: Estudo De Caso Do Website Da Nrsystem. International Journal of Professional Business Review, 2(2), 52-64.

CRED - Centre for Research on the Epidemiology of Disasters. Natural Disasters 2018. 2019. Disponível em: <https://www.cred.be/publications>. Acesso em: 10 jan. 2018

CRUZ, I. C.; DO NASCIMENTO SILVA, T. T.; BUENO, M. J. C. (2017). Complexidade na distribuição de donativos na logística humanitária. O caso de mariana. South American Development Society Journal, 2(5), 01-13.

CYBIS, W.; BETIOL, A. H.; FAUST, R. (2015). Ergonomia e usabilidade: conhecimentos, métodos e aplicações, atualizada e ampliada. Novatec, SP.

DA COSTA, F. M.; DARÉ, P. R. C.; VELOSO, A. R. (2004). From Consumer Behavior to Donor Behavior: Adapting Marketing Concepts. Brazilian Business Review, 1(1), 45-62.

DE FARIA CORDEIRO, K., CAMPOS, M. L. M., \& BORGES, M. R. (2014, May). Adaptive integration of information supporting decision making: $A$ case on humanitarian logistic. In ISCRAM.

DENZIN, N. K.; LINCOLN, Y. S. (2006). O planejamento da pesquisa qualitativa: teorias e abordagens. In $\mathrm{O}$ planejamento da pesquisa qualitativa: teorias e abordagens.

ECKHARDT, D.; LEIRAS, A. (2015). A disaster management framework based on the overview of the existent tools on top of a multi-criteria decision. In Proceedings of the 26th Annual POMS Conference. Washington.

ERTEM, M. A.; BUYURGAN, N.; ROSSETTI, M. D. (2010). Multiple-buyer procurement auctions framework for humanitarian supply chain management. International Journal of Physical Distribution ; Logistics Management, 40(3), 202-227.

ERTEM, M.; BUYURGAN, N. (2011). An auction-based framework for resource allocation in disaster relief. Journal of Humanitarian Logistics and Supply Chain Management, 1(2), 170-188.

FILARDI, A. L.; TRAINA, A. J. M. (2008). Montando questionários para medir a satisfação do usuário: avaliação de interface de um sistema que utiliza técnicas de recuperação de imagens por conteúdo. In Proceedings of the VIII Brazilian Symposium on Human Factors in Computing Systems (pp. 176-185). Sociedade Brasileira de Computação. 
FONTAINHA, T. C. et al. Process management and models for disaster response. Rio de janeiro: Puc-Rio-CTC-DEI, 2018, 34p. Relatório Técnico, 2018.

FORZA, C. (2002). Survey research in operations management: a process-based perspective. International journal of operations ; production management, 22(2), 152-194.

FRITZ, C. E.; MATHEWSON, J. H. (1957). "Convergent behavior: A disaster control problem." Special Rep. for the Committee on Disaster Studies, Disaster Study No. 9, Publication 476, National Academy of Sciences, Washington, DC, 3-28.

FRITZ INSTITUTE. Helios On-Demand Software: Tactical Visibility for the Humanitarian Supply Chain. Disponível em: <http://www.fritzinstitute.org/PDFs/HELIOS/HELIOS\%20OVERVIEW.pdf>.

Acesso em: 14 ago. 2018.

FUDALINSKI, J.; PAWLAK, K. (2012). Conditions of shaping the procurement function in the process of development of the sector of non-profit organizations. Contemporary dilemmas of management. Krakow Society for Education, Krakow, 57-79.

GELAN, A. (2006). Cash or food aid? A general equilibrium analysis for Ethiopia. Development Policy Review, 24(5), 601-624.

GONÇALVES, M. B.; LIMA, F. S. (2018). A logística humanitária no contexto da pesquisa, ensino e extensão universitária. Revista Gestão; Sustentabilidade Ambiental, 7, 19-30.

GREGORIO, L. T. D. Função de Logística na Resposta a Desastres: Estruturação da Administração de Doações. PROJETO SHS - Solução Habitacional Simples. Rio de Janeiro, 2012.

HARVEY, P.; BAILEY, S. (2011). Good practice review cash transfer programming in emergencies. Humanitarian Practice Network at Overseas Development Institute. Strategic Note Cash Transfers in Humanitarian Contexts.

HERLIN, H.; PAZIRANDEH, A. (2012). Nonprofit organizations shaping the market of supplies. International Journal of Production Economics, 139(2), 411-421.

HOLGUÍN-VERAS, J.; JALLER, M.; VAN WASSENHOVE, L. N.; PÉREZ, N.; WACHTENDORF, T. (2012). Material convergence: Important and understudied disaster phenomenon. Natural Hazards Review, 15(1), 1-12.

HOWARD, David; MACEACHREN, Alan M. Interface design for geographic visualization: Tools for representing reliability. Cartography and Geographic Information Systems, v. 23, n. 2, p. 59-77, 1996.

HOWDEN, M. (2009, May). How humanitarian logistics information systems can improve humanitarian supply chains: a view from the field. In Proceedings of the 6th international ISCRAM conference, Gothenburg, Sweden.

HUBER, M.; VAN BOVEN, L.; MCGRAW, A. P.; JOHNSON-GRAHAM, L. (2011). Whom to help? Immediacy bias in judgments and decisions about humanitarian 
aid. Organizational Behavior and Human Decision Processes, 115(2), 283293.

HWANG, G. J.; SUNG, H. Y.; HUNG, C. M.; HUANG, I.; TSAI, C. C. (2012). Development of a personalized educational computer game based on students' learning styles. Educational Technology Research and Development, 60(4), 623-638.

IDIS, Pesquisa Doação Brasil. 2015. Disponivel em: < https://www.idis.org.br/pesquisa-doacao-brasil/>. Acesso em: 12 nov. 2018.

IDIS, Country Giving Report. 2017. Disponível em: < https://www.idis.org.br/country-giving-report-2017-brasil/>. Acesso em: 12 nov. 2018.

IMPACTOS DAS DOAÇÕES DE MATERIAIS EM DESASTRES. USP. Disponível em: $\quad<$ http://usp.br/semanact/2017/evento/impactos-das-doacoes-de-materiaisem-desastres/>. Acesso em: 10 ago. 2018

INSTITUTO OPUS | Pesquisa Eleitoral, de Mercado e Opinião Pública (2018). Disponível em: <https://www.opuspesquisa.com/>. Acesso em: 24 mar. 2019

ISLAM, M. (2013). In-kind donation practices, challenges and strategies for NGOs and donors (Doctoral dissertation, Georgia Institute of Technology).

JOHN, L. (2018). Review of empirical studies in humanitarian supply chain management: Methodological considerations, recent trends and future directions. In The Palgrave handbook of humanitarian logistics and supply chain management (pp. 637-673). Palgrave Macmillan, London.

KERLINGER, F. N. (1966). Foundations of behavioral research.

KOESUMA, S., RIANTANA, R., SISWANTO, B., AJI PURNOMO, F., \& LELONO, S. (2017, November). dLOGIS: Disaster Logistics Information System. In Journal of Physics Conference Series (Vol. 909, No. 1).

KOVÁCS, G.; SPENS, K.M. (2007), "Humanitarian logistics in disaster relief operations", International Journal of Physical Distribution; Logistics Management, Vol. 37 No. 2, pp. 99-114

LANEROLLE, P., RATHNAYAKA, S., RUPASINGHE, H., MADHUSHANKA, S., SAMARAKOON, U., \& KASTHURIRATHNE, D. (2018, October). Donate. Ik: A Smart Donation Handling System. In 2018 National Information Technology Conference (NITC) (pp. 1-6). IEEE.

LARMAN, C. (2012). Applying UML and patterns: an introduction to object oriented analysis and design and interative development. Pearson Education India.

LEIRAS, A.; JR, I. DE B.; PERES, E. Q.; BERTAZZO, T. R.; YOSHIZAKI, H. T. Y. (2014). Literature review of humanitarian logistics research: trends and challenges. Journal of Humanitarian Logistics and Supply Chain Management, 4(1), 95130.

LICKFETT, J.; ASHISH, N.; MEHROTRA, S.; VENKATASUBRAMANIAN, N.; GREEN, J. (2008). The RESCUE disaster portal for disasters and emergency response. In Proceedings of the 5th International ISCRAM Conference. 
LOGISTIC CLUSTER. Logistics Operational Guide, 2015. Disponível em: < https://dlca.logcluster.org/display/LOG/Procurement>. Acesso em: 10 fev. 2019

MEIRIM, H. (2007). Logística humanitária e logística Empresarial, mmrbrasil.

MENDES, D. M. G., LEAL, J. E., DA SILVA JÚNIOR, O.S. (2017, November). Desenvolvimento de um sistema de apoio à Logística Humanitária. XXXI ANPET - Congresso Nacional de Pesquisa em Transporte. Anais. Recife PE. ANPET

MENDES, D. M. G.; LEAL, J. E.; FONTAINHA, T. C. Descrição de sistemas de gerenciamento de doações. PUC-RIO-CTC-DEI, 2019a, 14p. Relatório Técnico.

MENDES, D. M. G.; LEAL, J. E.; FONTAINHA, T. C. Descrição dos processos de doações e compras de organizaçãos de assistência humanitária. PUCRIO-CTC-DEI, 2019b, 20p. Relatório Técnico.

MOLANO, J. I. R.; YARA, E. S.; GARCÍA, L. K. J. (2015, June). Model for measuring usability of survey mobile apps, by analysis of usability evaluation methods and attributes. In Information Systems and Technologies (CISTI), 2015 10th Iberian Conference on (pp. 1-6). IEEE.

MONGEON, P.; PAUL-HUS, A. (2016). The journal coverage of Web of Science and Scopus: a comparative analysis. Scientometrics, 106(1), 213-228.

NEAL, D. M. (1997). Reconsidering the phases of disasters. International Journal of Mass Emergencies and Disasters, 15(2), 239-264.

NIELSEN, J. (1994). Usability engineering. Elsevier.

NIELSEN, J. "Why you only need to test with 5". Nielsen Norman Group. March 19, 2000. Disponível em < https://www.nngroup.com/articles/why-you-only-needto-test-with-5-users/>. Acesso em: 05 mai. 2019.

NO ONE IS PAYING ATTENTION TO THE WORST HUMANITARIAN CRISIS SINCE WORLD WAR II. The Washington Post $<$ https://www.washingtonpost.com/opinions/global-opinions/no-one-is-payingattention-to-the-worst-humanitarian-crisis-since-world-warii/2017/06/25/70d055f8-5767-11e7-ba90-

f5875b7d1876_story.html?noredirect $=$ on; utm_term $=.6133656 b 6473>$. Acesso em: 10 ago. 2018

OOSTERHOF, L.; HEUVELMAN, A.; PETERS, O. (2009). Donation to disaster relief campaigns: Underlying social cognitive factors exposed. Evaluation and program planning, 32(2), 148-157.

ORTUÑO, M. T., CRISTÓBAL, P., FERRER, J. M., MARTÍN-CAMPO, F. J., MUÑOZ, S., TIRADO, G., \& VITORIANO, B. (2013). Decision aid models and systems for humanitarian logistics. A survey. In Decision aid models for disaster management and emergencies (pp. 17-44). Atlantis Press, Paris.

ÖZDAMAR, L.; ERTEM, M. A. (2015). Models, solutions and enabling technologies in humanitarian logistics. European Journal of Operational Research, 244(1), $55-65$. 
ÖZPOLAT, K.; RILLING, J.; ALTAY, N.; CHAVEZ, E. (2015). Engaging donors in smart compassion: USAID CIDI's Greatest Good Donation Calculator. Journal of Humanitarian Logistics and Supply Chain Management, 5(1), 95-112.

PAN AMERICAN HEALTH ORGANIZATION. Emergency Preparedness, Disaster Relief Coordination Program, World Health Organization. Division of Emergency, Humanitarian Action. (2001). Humanitarian supply management and logistics in the health sector. Pan American Health Org.

PEREIRA, A. F., PADILHA, D., \& PROCÓPIO, L. L. (2016). Relpio: uma aplicação Mobilepara auxiliar no cadastro de vítimas de catástrofes naturais. Revista Eletrônica TECCEN, 9(1), 20-25.

PERIARD, G. Matriz GUT: Guia Completo. (2011). Disponível em: <http://www.sobreadministracao.com/matriz-gut-guia-completo/>. Acesso em: 24 nov. 2018

POBLET, M.; GARCÍA-CUESTA, E.; CASANOVAS, P. (2013). Crowdsourcing tools for disaster management: A review of platforms and methods. In International Workshop on Al Approaches to the Complexity of Legal Systems (pp. 261-274). Springer, Berlin, Heidelberg.

PUROHIT, H., CASTILlO, C., DIAZ, F., SHETH, A., \& MEIER, P. (2014). Emergency-relief coordination on social media: Automatically matching resource requests and offers. First Monday, 19(1).

SALVINO, E.; LEAL, J.E. (2012) Sistema de doações pela internet para a ajuda humanitária. Rio de Janeiro. 89p. Dissertação de Mestrado - Departamento de Engenharia Industrial, Pontifícia Universidade Católica do Rio de Janeiro.

SANTA ROSA, J. G.; MARQUES, T. (2014) Um estudo sobre a utilização de questionários de satisfação do usuário no desenvolvimento de interfaces. COUTINHO, SG; MOURA, M.; CAMPELLO, SB; CADENA, RA.

SANZ, F.; GALVEZ, R.; RUSU, C.; RONCAGLIOLO, S.; RUSU, V.; COLLAZOS, C. A.; QUIÑONES, D. (2016). A set of usability heuristics and design recommendations for u-Learning applications. In Information Technology: New Generations (pp. 983-993). Springer, Cham.

SCHULZ, S. F. (2009). Disaster relief logistics: benefits of and impediments to cooperation between humanitarian organizations (Vol. 15). Haupt Verlag AG.

SETIABUDI, D. H., WIDYADANA, I. G. A., HARSONO, V., \& WONGSO, R. C. (2018). A New Disaster Aid Information System Model for Indonesia Red Cross: A Case Study in East Java Province. Int. J Sup. Chain. Mgt Vol, 7(3).

SHAFIQ, B., AE CHUN, S., ATLURI, V., VAIDYA, J., \& NABI, G. (2012). Resource sharing using UICDS ${ }^{\mathrm{TM}}$ framework for incident management. Transforming Government: People, Process and Policy, 6(1), 41-61.

SHNEIDERMAN, B. (1998). Designing the user interface: Strategies for effective human. Computer Interaction. 
SIDRÃO, A.; LIMA, C. H. T.; PINTO, J.; BASTOS, W. Donare: Sistema de Gerenciamento de ações Humanitárias. Faculdade de Sistemas de Informação, Veris Faculdades, 2011.

SILIUS, K.; TERVAKARI, A. M. (2003). An evaluation of the usefulness of webbased learning environments. The evaluation tool into the portal of Finnish virtual university. In International Conference of Network Universities and e-learning. Valencia, España.

SILVA, D. R. E. DA; LEIRAS, A. Proposta conceitual de um sistema de gerenciamento de resposta a desastres. Rio de Janeiro, 2015. 85p. Dissertação de Mestrado - Departamento de Engenharia Industrial, Pontifícia Universidade Católica do Rio de Janeiro

SILVA, S. (2003). Qualidade de Software-Uma Abordagem Baseada na Satisfação do Usuário, Dissertação de Mestrado em Ciências de Engenharia. UENF, Campos dos Goytacazes-RJ.

SMILOWITZ, K.; DOLINSKAYA, I. (2011) Decision-making tools for distribution networks in disaster relief. Center for the Commercialization of Innovative Transportation Technologies - Northwestern University.

STARR, M. K.; VAN WASSENHOVE, L. N. (2014). Introduction to the special issue on humanitarian operations and crisis management. Production and Operations Management, 23(6), 925-937.

SUMI QUESTIONNAIRE HOMEPAGE. Disponível em <http://sumi.uxp.ie/>. Acesso em: 14 abr. 2019.

TATHAM, P.; SPENS, K. (2011). Towards a humanitarian logistics knowledge management system. Disaster Prevention and Management: An International Journal, 20(1), 6-26.

THOMAS, A. S.; KOPCZAK, L.R. (2005) From Logistics to Supply Chain Management: The Path Forward in the Humanitarian Sector.Fritz Institute, San Francisco, CA.

THOMÉ, A. M. T.; SCAVARDA, L. F.; SCAVARDA, A. J. (2016). Conducting systematic literature review in operations management. Production Planning, Control, 27(5), 408-420.

UN: WORLD FACING GREATEST HUMANITARIAN CRISIS SINCE 1945. BBC. Disponível em: https://www.bbc.com/news/world-africa-39238808 Acesso em:: 10 ago. 2018

UNISDR, M. (2017). UNISDR Terminology for Disaster Risk Redution. United Nations International Strategy for Disaster Reduction (UNISDR) Geneva, Switzerland.

VAN WASSENHOVE, L. N. (2006). Humanitarian aid logistics: supply chain management in high gear. Journal of the Operational Research Society, 57(5), 475-489.

VARELLA, L.; GONÇALVES, M. (2017). Avaliação de desempenho dos processos referentes a gestão de doações em cadeias de suprimentos humanitárias. In: 
XXXI ANPET - Congresso Nacional de Pesquisa em Transporte. Anais. Recife PE. ANPET.

VIEIRA, H.; BARANAUSKAS, M. C. C. (2003). Design e avaliação de interfaces humano-computador. Creative Commons, Brasil.

YIN, R. K. (2017). Case study research and applications: Design and methods. Sage publications.

ZAGEFKA, H.; NOOR, M.; BROWN, R.; DE MOURA, G. R.; HOPTHROW, T. (2011). Donating to disaster victims: Responses to natural and humanly caused events. European journal of social psychology, 41(3), 353-363. 


\section{Apêndice 1 - Protocolo de pesquisa}

Este protocolo visa padronizar os procedimentos de estudo de caso conforme indicado por Yin (2017). Segundo o autor, o protocolo deve indicar a seleção das fontes de dados, os instrumentos de pesquisa, procedimentos de coleta e análise de dados, a fim de uniformizar o desenvolvimento da pesquisa.

A - Definições iniciais do protocolo de pesquisa

A pergunta de pesquisa que orienta o objetivo que orienta o estudo de caso é: O sistema proposto é aceito pelas instituições? Além deste objetivo principal, há ainda objetivos secundários em caracterizar os processos de doações e aquisições das instituições, bem como identificar propostas de melhorias do ponto de vista das instituições.

A seleção dos casos é feita de acordo com diferentes critérios, a fim de estabelecer limites que definem o que pode ser estudado para ajudar a descobrir, confirmar ou qualificar os as hipóteses do estudo e identificar casos com características que destaquem as diferenças estudadas. Os critérios adotados no presente estudo encontram-se no Quadro 12.

Quadro 12 - Critérios de seleção das instituições

\begin{tabular}{|l|l|}
\hline \multicolumn{1}{|c|}{ Critérios } & \multicolumn{1}{c|}{ Meios de verificação } \\
\hline Atuar na assistência humanitária & Ser entidade sem fins lucrativos \\
\hline Atuar no Rio de Janeiro & $\begin{array}{l}\text { Ter sede/filial na cidade do Rio de } \\
\text { Janeiro }\end{array}$ \\
\hline $\begin{array}{l}\text { Atuar em campanhas de de } \\
\text { arrecadação de doações }\end{array}$ & $\begin{array}{l}\text { Ter atuado em pelo menos uma } \\
\text { campanha com arrecadação de } \\
\text { donativos }\end{array}$ \\
\hline $\begin{array}{l}\text { Ser representativa na área de } \\
\text { assistência humanitária }\end{array}$ & $\begin{array}{l}\text { Aval de estudiosos da área de } \\
\text { logística humanitária }\end{array}$ \\
\hline
\end{tabular}

No quadro 12 pode-se observar que para assegurar que as instituições possuem propósitos similares devem ser entidades sem fins lucrativos, que atuem na cidade do Rio de Janeiro e atuem em campanhas de arrecadação de donativos seja para desastres súbitos ou para assistência da população em situação de vulnerabilidade socioeconômica, além de possuir atuação coerente com a logística humanitária para estudiosos da área. 
São coletadas informações de cinco instituições (A, B, C, D e E), tendo cada uma delas um entrevistado sobre os processos atuais de doações, características operacionais, stakeholders envolvidos, e percepção quanto ao sistema. Optou-se por omitir informações referentes a identificação dos entrevistados e instituições para manter a confidencialidade.

\section{B - Estruturação técnica para coleta de dados}

As fontes de dados são múltiplas e no que tange as organizações, as fontes primárias para coleta de dados empíricos são: entrevistas semiestruturadas, com questões abertas para possibilitar flexibilidade e maior participação dos respondentes, sua condução é baseada nos tópicos contidos no roteiro da entrevista, utilizado para avaliar o perfil das organizações e interesse das mesmas pela utilização do sistema. Em seguida, é feita a segunda parte da entrevista, a fim de avaliar a capacidade de recebimento e investimento das organizações para a utilização do sistema e por fim é realizada a avaliação da usabilidade do sistema através de um teste de usabilidade. A Figura 6 mostra as etapas para avaliação, a fim de facilitar o entendimento da etapa de coleta de dados.

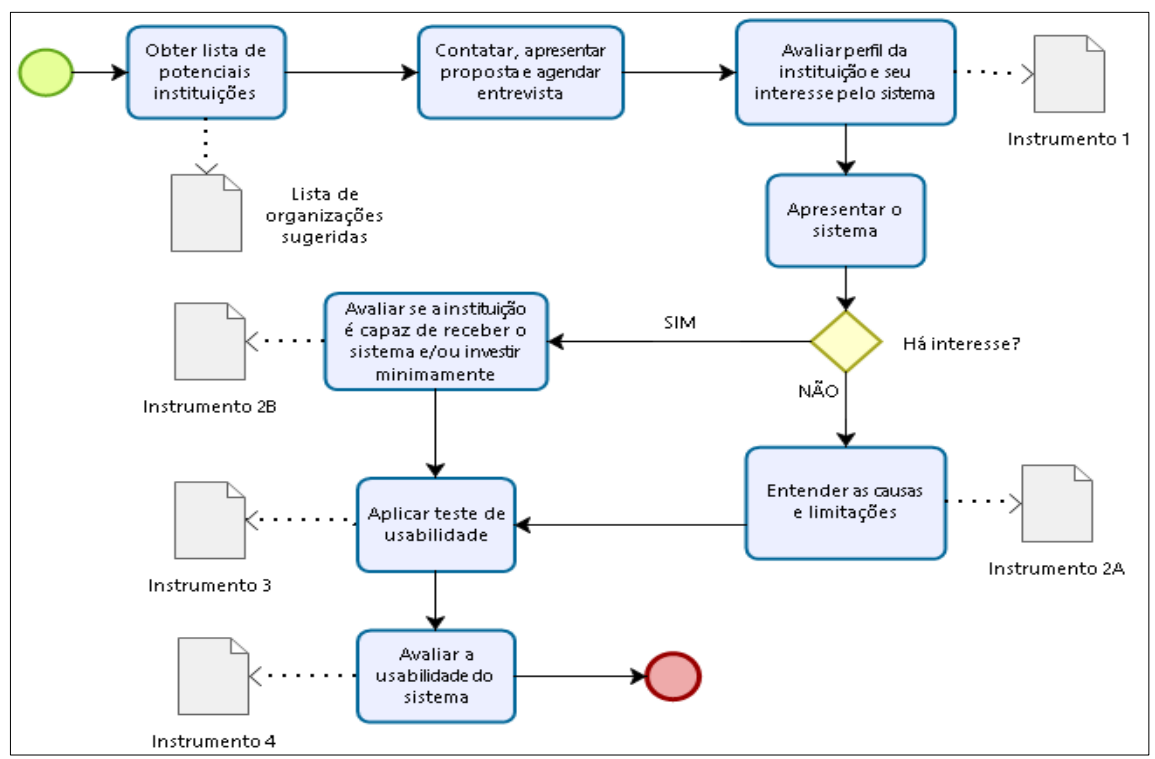

Figura 6 - Etapas de coleta de dados nas instituições

As entrevistas foram realizadas entre 18 de dezembro de 2018 e 22 de janeiro de 2019. Os materiais utilizados para o procedimento de coleta de dados são: roteiro de entrevista, bloco para anotações, aparelho eletrônico de gravação, 
celular e notebook com o protótipo instalado para execução do teste de usabilidade.

$$
\text { C - Instrumentos de pesquisa }
$$

Para realizar a coleta de dados é utilizado um roteiro de entrevista dividido em três partes. O Quadro 13 traz a primeira parte, cujo foco é a identificação dos problemas apresentados na instituição que visam ser mitigados pelo SmartDonation, a caracterizando como público alvo; é feita ainda a identificação dos problemas enfrentados no que tange as doações e compras e como é feito o gerenciamento pela instituição, em seguida a entrevistadora faz uma pequena demonstração das funcionalidades do sistema a fim de avaliar se o sistema é do interesse da instituição.

Quadro 13 - Instrumento de pesquisa 1

\begin{tabular}{|c|c|c|}
\hline & Perguntas & Fonte \\
\hline \multirow{8}{*}{ 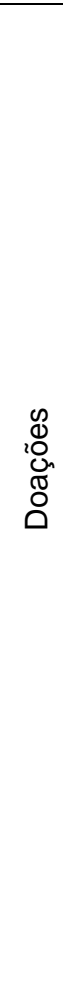 } & O gerenciamento de doações é um desafio para a instituição? & Autores (2018) \\
\hline & Como é o processo atual de doações? & Autores (2018) \\
\hline & $\begin{array}{l}\text { Há recebimento de suprimentos não prioritários (que não deveriam } \\
\text { chegar para uma determinada campanha em um dado momento) ou } \\
\text { inutilizáveis (próximo a data de expiração, violados, etc.). Se sim, } \\
\text { qual o procedimento com os mesmos? }\end{array}$ & $\begin{array}{l}\text { PAHO, 2001; } \\
\text { Holguín-Veras } \\
\text { et al. }(2012 a)\end{array}$ \\
\hline & $\begin{array}{l}\text { Você considera que há desperdício e/ou excesso de suprimentos e } \\
\text { mão-de-obra para lidar com os itens não prioritários? }\end{array}$ & $\begin{array}{l}\text { Holguín-Veras } \\
\text { et al. }(2012 a)\end{array}$ \\
\hline & $\begin{array}{l}\text { A instituição durante as campanhas recebe maior doação de } \\
\text { suprimentos (materiais) ou dinheiro? }\end{array}$ & $\begin{array}{l}\text { Holguin-Veras, } \\
\text { et al. (2012a) }\end{array}$ \\
\hline & $\begin{array}{l}\text { A organização possui ações de conscientização sobre a melhor } \\
\text { maneira de doar e as consequências de cada tipo de doação para a } \\
\text { instituição e para os beneficiários? }\end{array}$ & $\begin{array}{l}\text { Alexander } \\
(2013)\end{array}$ \\
\hline & $\begin{array}{l}\text { Há algum tipo de avaliação e/ou programa de fidelização de } \\
\text { doadores? }\end{array}$ & $\begin{array}{l}\text { Eckhardt, e } \\
\text { Leiras (2015) }\end{array}$ \\
\hline & $\begin{array}{l}\text { De que maneira é realizado o acompanhamento do processo de } \\
\text { doações? } \\
\begin{array}{llll}\text { (a)Manualmente } & \text { (b) Planilha eletrônica } & \text { (c) Sistema interno(d) } \\
\text { Aplicação web } & \text { (e) Não fazemos acompanhamento }\end{array}\end{array}$ & Autores (2018) \\
\hline \multirow{2}{*}{ 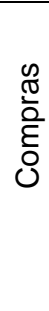 } & $\begin{array}{l}\text { Há levantamento da demanda necessária? Existe algum método de } \\
\text { previsão de demanda? Como é realizado? Há metas estabelecidas } \\
\text { para cada item? }\end{array}$ & Autores (2018) \\
\hline & $\begin{array}{l}\text { Os itens recebidos durante as campanhas são suficientes para } \\
\text { atender a população a ser atendida? Há muita divergência ao } \\
\text { programado com o que é executado? }\end{array}$ & $\begin{array}{l}\text { Arnette e } \\
\text { Zobel (2016) }\end{array}$ \\
\hline
\end{tabular}

(continua) 
Quadro 13 - Final

\begin{tabular}{|c|c|c|}
\hline \multirow[t]{4}{*}{ 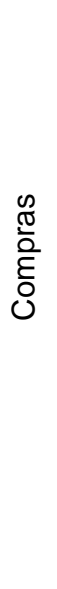 } & Há setor de compras? Quais as etapas do processo? & $\begin{array}{l}\text { Fudalinski e } \\
\text { Pawlak(2012) } \\
\text { Fontainha et } \\
\text { al. (2018); } \\
\text { Blecken } \\
(2010)\end{array}$ \\
\hline & Existe avaliação de fornecedores? & Autores (2018) \\
\hline & Considera a maneira atual de compras e gerenciamento eficaz? & Autores(2018) \\
\hline & $\begin{array}{l}\text { Caso a maior parte da obtenção de suprimentos fosse feita através } \\
\text { de compras subsidiadas por doações, considera esta uma maneira } \\
\text { mais eficaz e eficiente que a atualmente adotada? }\end{array}$ & Autores(2018) \\
\hline & Há interesse da instituição pelo sistema? & Autores (2018) \\
\hline
\end{tabular}

O Quadro 14 traz o instrumento de pesquisa 2A, que possui a função de avaliar as razões do não interesse da instituição. Este instrumento possui escala likert variando de 1 a 5, correspondendo a Discordo fortemente e Concordo fortemente, respectivamente.

Quadro 14 - Instrumento de pesquisa 2A

\begin{tabular}{|l|l|l|l|l|l|}
\hline & 1 & 2 & 3 & 4 & 5 \\
\hline $\begin{array}{l}\text { Acredito que o meu modo atual de gerenciamento de } \\
\text { doações seja o ideal ou suficiente. }\end{array}$ & & & & & \\
\hline $\begin{array}{l}\text { Falta de recursos técnicos (capacidade do servidor, } \\
\text { falta de quadro técnico na instituição para instalação } \\
\text { e manutenção, etc.). }\end{array}$ & & & & & \\
\hline Receio pela não aceitação do público em geral. & & & & & \\
\hline Falta de confiabilidade no sistema. & & & & & \\
\hline Outro. Qual? & & & & & \\
\hline
\end{tabular}

Já as questões referentes ao instrumento 2B são apresentadas a seguir, e visam investigar a capacidade por parte da instituição de receber e manter o sistema.

- Possui domínio próprio ou tem a possibilidade de adquirir? (ex: sitedainstituição.com.br, custo médio de $\mathrm{R} \$ 30,00$ por ano)

- Possui servidor dedicado ou tem a possibilidade de adquirir (custo médio de $R \$ 40,00$ por mês)? 
- Possui setor direcionado para TI ou tem a possibilidade de investir para este projeto?

- Com o treinamento sendo fornecido (12 horas), há na instituição pessoas disponíveis para serem treinadas e disponíveis para gerenciar o sistema?

Além do roteiro de entrevista, outro instrumento de pesquisa é utilizado, a fim de padronizar também o teste de usabilidade a ser realizado pelos respondentes. A seguir é apresentado o roteiro de teste de usabilidade, constando as tarefas a serem executadas pelos representantes das instituições.

\section{Instrumento de pesquisa 3 - Roteiro de teste de usabilidade}

1. Efetuar login no sistema

Login: adm@puc-rio.br

Senha: adm

2. Cadastrar produtos na base de dados

Água mineral (2 litros)

Kit Médico (gaze, álcool, curativo)

3. Atualizar índices de consumo

1 kit / pessoa / 5 dias

$2 \mathrm{~L} /$ pessoa afetada / dia

4. Cadastrar evento

- Deslizamento Morro do Bumba (Niterói - RJ)

- 66 pessoas afetadas

- 10 pessoas enfermas

- Ocorrência no dia 10/11/2018

- 5 dias de assistência

5. Identificar necessidades de suprimentos

6. Solicitar cotação de produtos

7. Calcular custos unitários

8. Publicar campanha

9. Verificar campanha no painel

10. Enviar pedidos aos fornecedores

A terceira parte consiste na realização do teste de usabilidade que utiliza o Instrumento 4 para execução das tarefas que possibilitam a avaliação da usabilidade, que é realizada mesmo que a instituição não apresente interesse no 
sistema, pois acredita-se que pode ser uma importante fonte de aprimoramento do sistema. A seleção do instrumento para a presente pesquisa é baseada no estudo de Assila e Ezzedine (2016), o qual indica o SUMI como o instrumento com maior equilíbrio em termos de cobertura de critérios e maior agilidade (menor número de perguntas), sendo o instrumento escolhido para a avaliação de usabilidade. O instrumento pode ser visto no Anexo 1.

D - Análise de dados

Para a análise de dados provenientes das agências humanitárias da primeira parte da entrevista é feita a análise intracaso, através da análise dos dados coletados em cada estudo de caso separadamente e posteriormente a análise intercaso, analisando os dados coletados em conjunto. As entrevistas são transcritas e armazenadas em meio eletrônico e é feita a geração de resumos que possibilitem a posterior triangulação dos dados.

Para a aplicação do teste de usabilidade é utilizado um roteiro de aplicação desenvolvido com algumas das principais funcionalidades do sistema a fim de que o usuário possa realizá-las e basear sua avaliação em tarefas reais. O método "pensar em voz alta" ou verbalização, é utilizado a fim de capturar as impressões do usuário ao realizar determinada tarefa. Todo o processo é gravado em áudio em concomitância com as anotações efetuadas manualmente pelo aplicador do teste. Após a execução das tarefas, os usuários estão aptos a responder o Instrumento 4, o SUMI. A análise deste instrumento é feita através de um software exclusivo para sua análise, o SUMISCO, que fornece relatórios de cada um dos aspectos de usabilidade. Além dessa ferramenta, a aplicadora do teste ranqueia as atividades mais críticas, por meio da matriz GUT (Apêndice 4), elencando assim quais das tarefas é mais crítica do ponto de vista do funcionamento do sistema para as instituições. 


\section{Apêndice 2 - Instrumentos da Survey}

A - Definições iniciais

Para realizar a coleta de dados pela perspectiva dos doadores é utilizado um questionário online na plataforma OnlinePesquisa como instrumento, com perguntas fechadas a fim de trazer uma análise quantitativa sobre a aceitabilidade do sistema pelo público geral, focado na percepção do usuário quanto a doações e ao sistema.

O principal objetivo da survey nesta pesquisa é investigar se o sistema proposto é aceito por potenciais doadores, além de investigar outras questões ligas aos objetivos secundários, que passam pela compreensão de fatores que influenciam no ato de doar e não doar, além de avaliar o potencia do sistema em modificar a percepção dos respondentes em relação a doações monetárias. A fim de capturar essas percepções o instrumento foi dividido em cinco partes. A Figura 7 ilustra a sequência de cada um dos instrumentos na pesquisa.

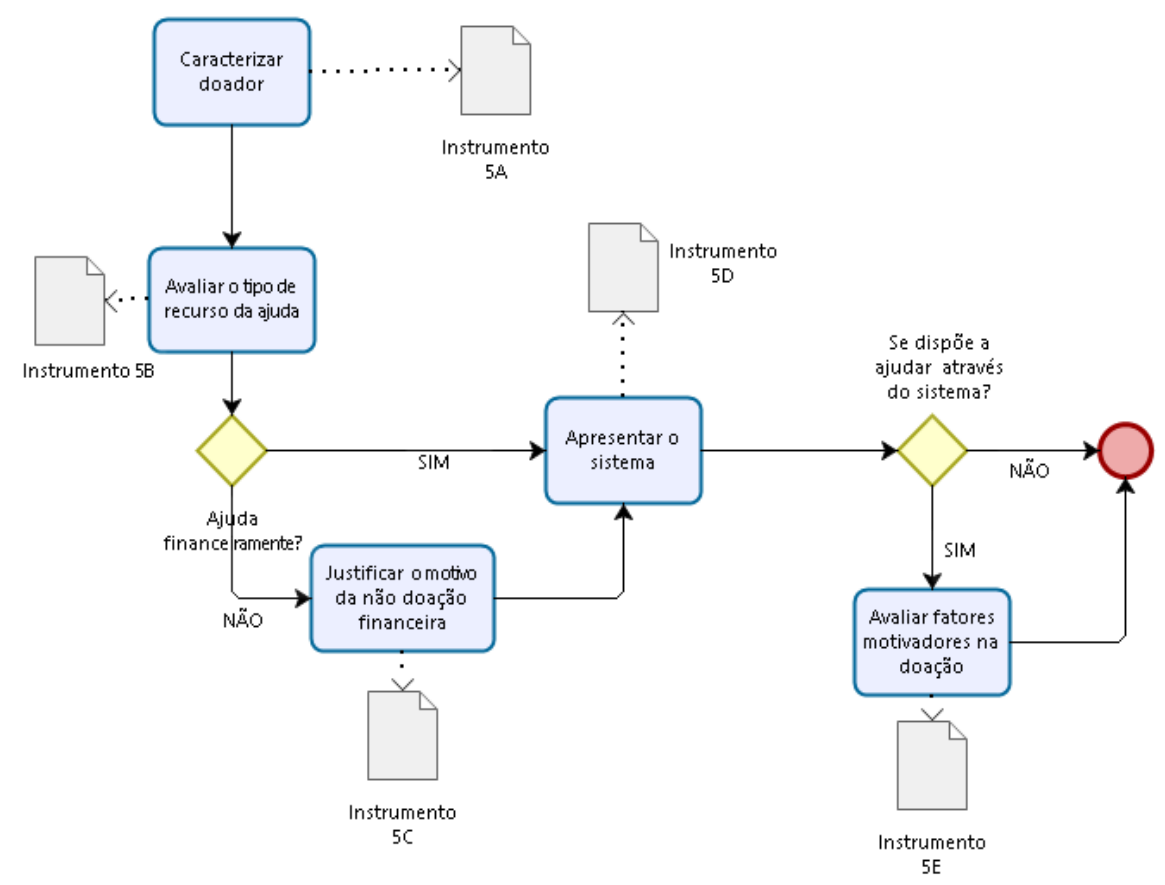

Figura 7 - Fluxo do questionário do doador 
B - Instrumentos de pesquisa

O instrumento $5 \mathrm{~A}$, a seguir, é utilizado para caracterizar o respondente em aspectos referentes a gênero, idade, nível de escolaridade, religião e renda.

\section{Instrumento 5A}

- Gênero:

( ) Feminino

( ) Masculino

( ) Outro:

- Idade:

- Nível de escolaridade

( ) Ensino Fundamental

( ) Ensino Médio

( ) Ensino Superior

- Informe sua renda FAMILIAR: (salário mínimo atual: R\$954)

( ) Até 2 salários mínimos

( ) entre 2 e 4 salários mínimos

( ) entre 4 e 6 salários mínimos

( ) entre 6 e 8 salários mínimos

( ) entre 8 e 10 salários mínimos

( ) entre 10 e 15 salários mínimos

( ) acima de 15 salários mínimos

- Qual a sua denominação religiosa? (Fonte: Pesquisa Doação Brasil,2015)

( ) Nenhuma

( ) Católica

( ) Espírita

( ) Evangélica

( ) Candomblé

( ) Outras

Já o instrumento 5B e 5D são utilizados para identificar preferências nos tipos de doação/ajuda, contudo o instrumento 5B é utilizado antes da apresentação do sistema, enquanto o 5D é apresentado posteriormente. Aqui é 
importante elucidar como se dá o fluxo sequencial do questionário quando há questões múltiplas escalonadas. A sequência segue para o fluxo "SIM" caso clique em "Disposto" ou "Muito Disposto" para doações financeiras em qualquer tipo de desastre, caso contrário o fluxo a ser seguido é o NÃO na Figura 7 anteriormente apresentada.

\section{Instrumento 5B e 5D}

Responda o quão disposto (a) estaria em ajudar nos seguintes casos:

- Em casos de desastres de início súbito e de causas naturais, como furacões e terremotos:

\begin{tabular}{|c|c|c|l|l|l|}
\hline & $\begin{array}{c}\text { Nada } \\
\text { disposto }\end{array}$ & $\begin{array}{c}\text { Pouco } \\
\text { disposto }\end{array}$ & Indiferente & Disposto & Muito disposto \\
\hline Suprimentos & & & & & \\
\hline Vestuário & & & & & \\
\hline Doação Financeira & & & & & \\
\hline
\end{tabular}

- Em casos de desastres de início lento e de causas naturais, como seca e fome:

\begin{tabular}{|c|c|c|c|c|c|}
\hline & $\begin{array}{c}\text { Nada } \\
\text { disposto }\end{array}$ & $\begin{array}{c}\text { Pouco } \\
\text { disposto }\end{array}$ & Indiferente & Disposto & Muito disposto \\
\hline Suprimentos & & & & & \\
\hline Vestuário & & & & & \\
\hline Doação \\
Financeira
\end{tabular}

- Em casos de desastres de início súbito e decorrentes de ações humanas, como ataques terroristas e vazamentos químicos:

\begin{tabular}{|c|c|c|l|l|l|}
\hline & $\begin{array}{c}\text { Nada } \\
\text { disposto }\end{array}$ & $\begin{array}{c}\text { Pouco } \\
\text { disposto }\end{array}$ & Indiferente & Disposto & Muito disposto \\
\hline Suprimentos & & & & & \\
\hline Vestuário & & & & & \\
\hline Doação Financeira & & & & & \\
\hline
\end{tabular}

- Em casos de desastres de início lento e decorrentes de ações humanas, como crises políticas e de refugiados:

\begin{tabular}{|c|c|c|c|c|c|}
\hline & $\begin{array}{c}\text { Nada } \\
\text { disposto }\end{array}$ & $\begin{array}{c}\text { Pouco } \\
\text { disposto }\end{array}$ & Indiferente & Disposto & Muito disposto \\
\hline Suprimentos & & & & & \\
\hline
\end{tabular}




\begin{tabular}{|c|l|l|l|l|l|}
\hline Vestuário & & & & & \\
\hline Doação Financeira & & & & & \\
\hline
\end{tabular}

O instrumento $5 \mathrm{C}$ visa detectar os fatores que influem na não-doação, e é descrito a seguir no Quadro 15.

- Assinale as razões para a não doação em dinheiro: (Fontes: Pesquisa Doação Brasil, 2015; da Costa, Daré e Veloso, 2004)

\section{Quadro 15 - Instrumento de pesquisa 5C}

\begin{tabular}{|c|c|c|}
\hline & Opções & Fontes \\
\hline ( ) & Não doo porque me faltam recursos financeiros & da Costa, Daré, e Veloso, 2004 \\
\hline ( ) & Não confio em entidades sem fins lucrativos & $\begin{array}{l}\text { Pesquisa Doação Brasil, 2015; } \\
\text { da Costa, Daré e Veloso, } 2004\end{array}$ \\
\hline ( ) & $\begin{array}{c}\text { Não gosto da forma como as entidades costumam } \\
\text { me abordar para pedir doações, considerando-as } \\
\text { muito invasivas }\end{array}$ & da Costa, Daré, e Veloso, 2004 \\
\hline ( ) & Acho complicado fazer uma doação & Pesquisa Doação Brasil, 2015 \\
\hline ( ) & $\begin{array}{c}\text { Problemas sociais são de responsabilidade do } \\
\text { governo }\end{array}$ & Pesquisa Doação Brasil, 2015 \\
\hline ( ) & Não sei como o dinheiro será utilizado & $\begin{array}{l}\text { Pesquisa Doação Brasil, 2015; } \\
\text { da Costa, Daré e Veloso, } 2004\end{array}$ \\
\hline ( ) & $\begin{array}{c}\text { Tive experiências negativas com doações } \\
\text { anteriormente }\end{array}$ & $\begin{array}{l}\text { Pesquisa Doação Brasil, 2015; } \\
\text { da Costa, Daré e Veloso, } 2004\end{array}$ \\
\hline ( ) & $\begin{array}{l}\text { Resolver os problemas sociais é de responsabilidade } \\
\text { do governo }\end{array}$ & Pesquisa Doação Brasil, 2015 \\
\hline ( ) & $\begin{array}{c}\text { Tenho medo de me comprometer e não poder } \\
\text { cumprir }\end{array}$ & Pesquisa Doação Brasil, 2015 \\
\hline ( ) & O processo de doação é complicado & Pesquisa Doação Brasil, 2015 \\
\hline ( ) & Não existe incentivo fiscal & Pesquisa Doação Brasil, 2015 \\
\hline ( ) & $\begin{array}{c}\text { O modo como as organizações ajudam as pessoas } \\
\text { não resolve o problema }\end{array}$ & Pesquisa Doação Brasil, 2015 \\
\hline ( ) & Não conheço os meios de ajuda e instituições & Pesquisa Doação Brasil, 2015 \\
\hline ( ) & Não tive exemplos/Não tenho o hábito & Pesquisa Doação Brasil, 2015 \\
\hline ( ) & Ninguém me pediu & Pesquisa Doação Brasil, 2015 \\
\hline
\end{tabular}

A apresentação conceitual do sistema é feita independentemente da resposta dada, o vídeo por se acessado através do seguinte link: https://youtu.be/Vz5UN3As60s__O vídeo traz além da interface do sistema, uma breve introdução sobre a problemática das doações, com o seguinte texto: "Após assistir o vídeo e com a possibilidade de realizar a doação financeira pelo sistema 
proposto (SmartDonation), responda o quão disposto(a) estaria em ajudar nos seguintes casos:". O respondente é direcionado para o instrumento 5D. Dessa forma, pode-se avaliar se o sistema é capaz de promover mudanças no comportamento dos respondentes.

Já o instrumento $5 \mathrm{E}$ visa avaliar as preferências dos doadores e fatores mais influentes na decisão de doar.

\section{Instrumento 5E}

- Qual o valor da doação que você estaria disposta(o) a fazer?

\begin{tabular}{|l|l|l|l|l|}
\hline & $\begin{array}{c}1 \text { a } 3 \text { vezes } \\
\text { ao ano }\end{array}$ & $\begin{array}{c}4 \text { a } 6 \text { vezes } \\
\text { ao ano }\end{array}$ & $\begin{array}{c}7 \text { a } 9 \text { vezes } \\
\text { ao ano }\end{array}$ & $\begin{array}{c}10 \text { a } 12 \\
\text { vezes ao } \\
\text { ano }\end{array}$ \\
\hline até $\mathrm{R} \$ 15,00$ & & & & \\
\hline entre $\mathrm{R} \$ 15,00$ e $\mathrm{R} \$ 30,00$ & & & & \\
\hline entre $\mathrm{R} \$ 30,00$ e $\mathrm{R} \$ 50,00$ & & & & \\
\hline entre $\mathrm{R} \$ 50,00$ e $\mathrm{R} \$ 75,00$ & & & & \\
\hline entre $\mathrm{R} \$ 75,00$ e $\mathrm{R} \$ 100,00$ & & & & \\
\hline entre $\mathrm{R} \$ 100,00$ e $\mathrm{R} \$ 200,00$ & & & & \\
\hline acima de $\mathrm{R} \$ 200,00$ & & & & \\
\hline
\end{tabular}

- Classifique de acordo com o nível de importância os fatores que justificam a doação:

\begin{tabular}{|c|c|c|c|c|c|c|}
\hline & $\begin{array}{c}\text { Nada } \\
\text { Importante }\end{array}$ & $\begin{array}{c}\text { Pouco } \\
\text { Importante }\end{array}$ & Neutro & Importante & $\begin{array}{c}\text { Muito } \\
\text { Importante }\end{array}$ & Fonte \\
\hline $\begin{array}{c}\text { Preocupação } \\
\text { social }\end{array}$ & & & & & & $\begin{array}{l}\text { PDB, 2015; da } \\
\text { Costa, Daré, e } \\
\text { Veloso, } 2004\end{array}$ \\
\hline $\begin{array}{c}\text { Identificação } \\
\text { com a } \\
\text { organização }\end{array}$ & & & & & & $\begin{array}{l}\text { PDB, 2015; da } \\
\text { Costa, Daré, e } \\
\text { Veloso, } 2004\end{array}$ \\
\hline $\begin{array}{c}\text { Satisfação } \\
\text { interna } \\
\text { gerada }\end{array}$ & & & & & & $\begin{array}{l}\text { PDB, 2015; da } \\
\text { Costa, Daré, e } \\
\text { Veloso, } 2004\end{array}$ \\
\hline $\begin{array}{l}\text { Imagem } \\
\text { pessoal }\end{array}$ & & & & & & $\begin{array}{c}\text { da Costa, Daré, e } \\
\text { Veloso, } 2004\end{array}$ \\
\hline $\begin{array}{l}\text { Minha } \\
\text { religião } \\
\text { prega a } \\
\text { caridade }\end{array}$ & & & & & & $\begin{array}{c}\text { Pesquisa Doação } \\
\text { Brasil, } 2015\end{array}$ \\
\hline
\end{tabular}


- Classifique a importância dos diferentes tipos de informação na hora avaliar a confiabilidade da instituição: (Fonte: da Costa, Daré, e Veloso, 2004)

\begin{tabular}{|c|c|l|l|l|l|}
\hline & $\begin{array}{c}\text { Nada } \\
\text { Importante }\end{array}$ & & & Muito \\
\hline $\begin{array}{c}\text { Histórico da entidade (prêmios } \\
\text { recebidos, campanhante } \\
\text { realizadas, reconhecimento } \\
\text { público, etc.) }\end{array}$ & & & & & \\
\hline $\begin{array}{c}\text { Área e foco de atuação } \\
\text { Quem são os responsáveis e } \\
\text { gestores da instituição. } \\
\text { Orientação religiosa da } \\
\text { instituição. }\end{array}$ & & & & & \\
\hline $\begin{array}{c}\text { A instituição se pautar pela } \\
\text { transparência das suas ações e } \\
\text { objetivos. }\end{array}$ & & & & & \\
\hline $\begin{array}{c}\text { A instituição utilizar técnicas de } \\
\text { captação de recursos que são } \\
\text { apropriadas e não invasivas. }\end{array}$ & & & & & \\
\hline $\begin{array}{c}\text { Existirem controles adequados } \\
\text { das atividades da organização }\end{array}$ & & & & & \\
\hline
\end{tabular}

- Assinale a(s) ferramenta(s) de mídia determinante ou mais conveniente na busca de informações e solicitação de doações: (Fonte:adaptado de da Costa, Daré, e Veloso, 2004; Pesquisa Doação Brasil, 2012)

( ) TV

( ) Correio

( ) E-mail (mala-direta)

( ) Redes sociais

( ) Solicitação online ao navegar na internet (anúncios)

( )Campanhas publicitárias de instituições sem fins lucrativos

( ) Ligação telefônica

( ) SMS

( ) Aplicativo no celular

( ) Abordagem pessoal (domicílio/local público)

( )Outra. Qual?

- Qual a melhor forma de pagamento? (da Costa, Daré, e Veloso, 2004; Pesquisa

Doação Brasil, 2015) 
( ) Boleto

( ) Cartão de crédito

( ) Débito em conta corrente

( ) Depósito bancário

( ) Ligação telefônica (0800)

( ) Em dinheiro na própria instituição

( ) Outra:

- Qual forma de acompanhar o que é realizado a partir das doações prefere: (da Costa, Daré, e Veloso, 2004)

( ) Através de e-mails informativos com um balanço sobre a campanha

( ) Através de publicações em mídias

( ) No próprio site da instituição.

( ) Através de reportagens na mídia (rádio, televisão, sites, etc.)

( ) Outra:

- Classifique os tipos de auditoria:

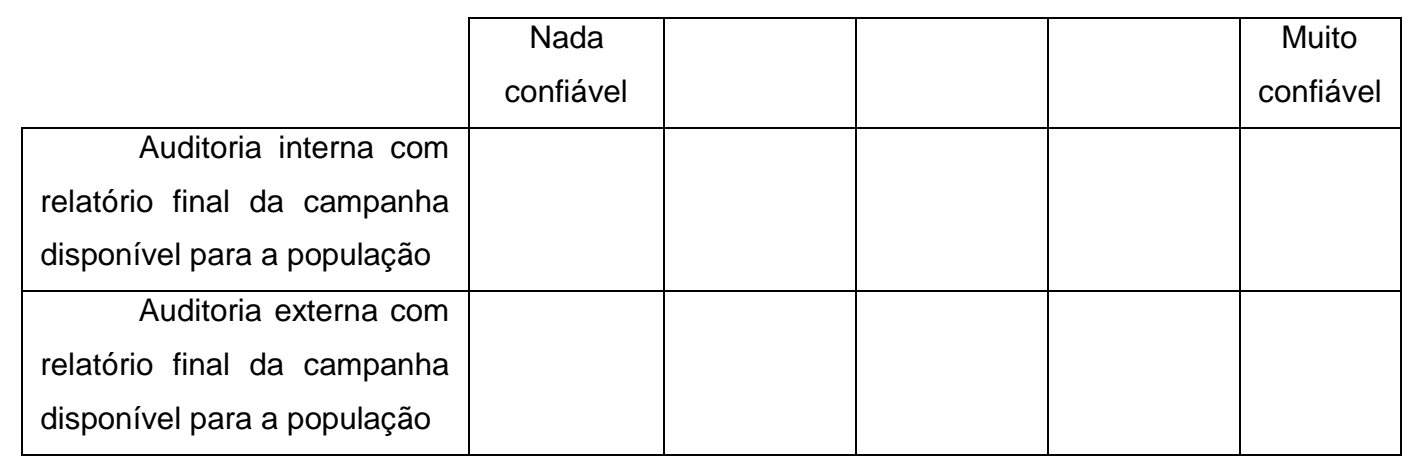

- Ao fim da doação, qual o tipo de feedback espera?

( ) Certificado de doação

( ) Email de agradecimento

Outro:

- Recomendaria a utilização desse tipo de sistema a outras pessoas?

( ) $\operatorname{Sim}$ ( ) Não

C - Análise de dados

A coleta de dados foi realizada entre os dias 21 de dezembro de 2018 a 30 de janeiro de 2019 em caráter transversal, ou seja, uma única vez ao longo do 
tempo. Os dados incompletos podem ser classificados como não respostas parciais, que é o termo utilizado entre não respostas totais e de item, ocorrem quando um participante corta a entrevista no meio, quando um respondente em uma pesquisa de painel não fornece dados para um ou mais grupos do painel, ou quando um respondente em uma pesquisa multifásica fornece dados para algumas, mas não todas as fases de coleta de dados. A abordagem selecionada para lidar com esses dados é a de ponderação (Brick e Kalton,1996), na qual, os não-participantes parciais são eliminados do arquivo de análise, envolvendo o descarte das respostas que os não-respondentes parciais forneceram.

Os instrumentos são analisados por meio de estatística descritiva, a fim de evidenciar padrões e sumarizar dados. 


\section{Apêndice 3 - Funcionalidades e características}

Quadro 16 - Funcionalidades e características dos sistemas

\begin{tabular}{|c|c|c|}
\hline $\begin{array}{l}\text { Funcionalidade / } \\
\text { Característica }\end{array}$ & Referência & Descrição \\
\hline $\begin{array}{l}\text { Cadeia de } \\
\text { Suprimentos } \\
\text { (Projeto e } \\
\text { Desenho) }\end{array}$ & $\begin{array}{l}\text { Blecken } \\
(2009)\end{array}$ & $\begin{array}{l}\text { Realizar um projeto para a Cadeia de Suprimentos } \\
\text { visando a concepção estratégica de toda a rede de } \\
\text { oferta e demanda com o objetivo de alcançar uma } \\
\text { rentabilidade ótima. }\end{array}$ \\
\hline $\begin{array}{c}\text { Cadeia de } \\
\text { Suprimentos } \\
\text { (Planejamento) }\end{array}$ & $\begin{array}{l}\text { Blecken } \\
(2009)\end{array}$ & $\begin{array}{l}\text { Planejar a Cadeia de Suprimentos em todas as } \\
\text { tarefas de planejamento estratégico, tático e } \\
\text { operacional, de forma a otimizar a execução dos } \\
\text { processos. }\end{array}$ \\
\hline $\begin{array}{l}\text { Cadeia de } \\
\text { Suprimentos } \\
\text { (Execução) }\end{array}$ & $\begin{array}{c}\text { Blecken } \\
(2009)\end{array}$ & $\begin{array}{l}\text { Ser capaz de gerenciar a cadeia de suprimentos, } \\
\text { doação de recursos financeiros, equipamentos, } \\
\text { materiais ou outros itens, de acordo com a } \\
\text { necessidade do desastre, da melhor maneira } \\
\text { possível. Deve possuir um sistema de } \\
\text { gerenciamento de alertas que informa ao usuário os } \\
\text { possíveis gargalos e incidentes quando comparados } \\
\text { com limites pré-definidos no sistema. }\end{array}$ \\
\hline Documentação & $\begin{array}{l}\text { Blecken } \\
(2009)\end{array}$ & $\begin{array}{l}\text { Possuir documentação de fácil acesso e em formato } \\
\text { objetivo. Documentação deve ser acessível on-line, } \\
\text { bem como remotamente. }\end{array}$ \\
\hline Relatórios & $\begin{array}{c}\text { Blecken } \\
\text { (2009) }\end{array}$ & Gerar relatórios (internos e externos) em tempo real. \\
\hline Acessibilidade & $\begin{array}{c}\text { Blecken } \\
\text { (2009) }\end{array}$ & $\begin{array}{l}\text { Ser acessível localmente e remotamente através da } \\
\text { Internet. }\end{array}$ \\
\hline Controladoria & $\begin{array}{c}\text { Blecken } \\
(2009)\end{array}$ & $\begin{array}{l}\text { Ser capaz de fornecer informações financeiras } \\
\text { através de relatórios. }\end{array}$ \\
\hline Cross-linking & $\begin{array}{l}\text { Blecken } \\
(2009)\end{array}$ & $\begin{array}{l}\text { Ser intra-organizacional, por exemplo, armazéns } \\
\text { regionais podem ser conectados com armazéns } \\
\text { centrais para ganhar visibilidade dos estoques da } \\
\text { cadeia de fornecimento. Oferecer possibilidades de } \\
\text { cross-link com o software usado em outros } \\
\text { departamentos da mesma organização, como } \\
\text { recursos humanos e de finanças. }\end{array}$ \\
\hline
\end{tabular}

(continua)

Quadro 16 - Continuação 


\begin{tabular}{|c|c|c|}
\hline $\begin{array}{l}\text { Modularidade e } \\
\text { Adaptabilidade }\end{array}$ & $\begin{array}{l}\text { Blecken } \\
(2009)\end{array}$ & $\begin{array}{l}\text { Ser possível a utilização de apenas alguns módulos } \\
\text { da ferramenta proposta de acordo com a } \\
\text { necessidade da fase do desastre }\end{array}$ \\
\hline Usabilidade & $\begin{array}{l}\text { Blecken } \\
\text { (2009) }\end{array}$ & Possuir interface de fácil utilização (intuitiva). \\
\hline Custos Diretos & $\begin{array}{l}\text { Blecken } \\
\text { (2009) }\end{array}$ & $\begin{array}{l}\text { Possibilitar o levantamento de custos relacionados } \\
\text { ao software e ao hardware. }\end{array}$ \\
\hline Custos Indiretos & $\begin{array}{c}\text { Blecken } \\
(2009)\end{array}$ & $\begin{array}{l}\text { Possibilitar o levantamento de custos relacionados } \\
\text { com treinamento, customização e manutenção. }\end{array}$ \\
\hline $\begin{array}{l}\text { Registro de } \\
\text { Voluntários }\end{array}$ & $\begin{array}{l}\text { Careem et al. } \\
\qquad(2006)\end{array}$ & $\begin{array}{l}\text { Registrar e gerenciar voluntários, divididos entre } \\
\text { entidades e indivíduos. }\end{array}$ \\
\hline Notificações & $\begin{array}{l}\text { Careem et al. } \\
\qquad(2006)\end{array}$ & $\begin{array}{l}\text { Permitir o envio de qualquer tipo de mensagem } \\
\text { relativa ao desastre (mensagens de texto, e-mail e } \\
\text { redes sociais). }\end{array}$ \\
\hline Interoperabilidade & $\begin{array}{l}\text { Shafiq et al. } \\
\qquad(2012)\end{array}$ & $\begin{array}{l}\text { Ser capaz de interagir com aplicações externas } \\
\text { através de um protocolo padronizado. Cada entidade } \\
\text { pode continuar trabalhando com suas próprias } \\
\text { ferramentas e, quando necessário, enviar } \\
\text { informações para um sistema central. Várias } \\
\text { organizações humanitárias com acesso as mesmas } \\
\text { informações, com o objetivo de facilitar a } \\
\text { coordenação e cooperação e, assim, melhorar a } \\
\text { eficiência das operações. }\end{array}$ \\
\hline $\begin{array}{l}\text { Segurança da } \\
\text { Informação }\end{array}$ & $\begin{array}{c}\text { Eckhardt e } \\
\text { Leiras (2015) }\end{array}$ & $\begin{array}{l}\text { Possuir níveis de segurança desenvolvidos de } \\
\text { acordo com as melhores práticas do mercado. }\end{array}$ \\
\hline Multiusuários & $\begin{array}{c}\text { Eckhardt e } \\
\text { Leiras (2015) }\end{array}$ & $\begin{array}{l}\text { Ser capaz de gerenciar vários usuários ao mesmo } \\
\text { tempo, níveis hierárquicos e com diferentes tipos de } \\
\text { acesso. }\end{array}$ \\
\hline $\begin{array}{l}\text { Avaliação de } \\
\text { doadores }\end{array}$ & $\begin{array}{c}\text { Eckhardt e } \\
\text { Leiras (2015) }\end{array}$ & $\begin{array}{l}\text { Possibilitar a avaliação dos doadores (entidades } \\
\text { humanitárias) baseada no cumprimento dos } \\
\text { compromissos acordados. }\end{array}$ \\
\hline $\begin{array}{c}\text { Base de Dados } \\
\text { Histórica }\end{array}$ & $\begin{array}{c}\text { Eckhardt e } \\
\text { Leiras (2015) }\end{array}$ & $\begin{array}{l}\text { Possuir uma base de dados histórica para consultas, } \\
\text { comparações entre desastres para estudos de } \\
\text { previsibilidade. }\end{array}$ \\
\hline $\begin{array}{c}\text { Etapa do ciclo de } \\
\text { desastre }\end{array}$ & $\begin{array}{l}\text { Poblet, García- } \\
\text { Cuesta e } \\
\text { Casanovas } \\
\text { (2013) }\end{array}$ & $\begin{array}{l}\text { Indica em qual das quatro fases do ciclo de gestão } \\
\text { de desastres a ferramenta pode ser aplicada } \\
\text { Mitigação, preparação, resposta ou recuperação }\end{array}$ \\
\hline Disponibilidade & $\begin{array}{l}\text { Poblet, García- } \\
\text { Cuesta e } \\
\text { Casanovas } \\
\text { (2013) }\end{array}$ & $\begin{array}{l}\text { Freeware - Gratuito e aberto. } \\
\text { Open Source - Acesso ao código-fonte, mas não } \\
\text { necessariamente gratuito. } \\
\text { Proprietário e licenciado - Comercializável }\end{array}$ \\
\hline
\end{tabular}

(continua)

Quadro 16 - Final 


\begin{tabular}{|c|c|c|}
\hline $\begin{array}{l}\text { Nível hierárquico } \\
\text { de implementação }\end{array}$ & $\begin{array}{c}\text { Howard e } \\
\text { MacEachren } \\
\text { (1996) }\end{array}$ & $\begin{array}{l}\text { Conceitual - Etapa em que são gerados modelos } \\
\text { descritivos conceituais com técnicas de } \\
\text { modelagem, por exemplo. } \\
\text { Operacional - É definida a estrutura de dados e } \\
\text { como são manipulados. Envolve a definição das } \\
\text { operações apropriadas para alcançar os objetivos } \\
\text { do nível conceitual } \\
\text { Implementação - Considerações sobre o que o } \\
\text { usuário terá que ver e entender de modo a interagir } \\
\text { com o sistema. Define-se e implementa-se a } \\
\text { aparência geral do sistema de fato. }\end{array}$ \\
\hline $\begin{array}{l}\text { Aplicação } \\
\text { (Interface) }\end{array}$ & $\begin{array}{c}\text { Poblet, García- } \\
\text { Cuesta e } \\
\text { Casanovas } \\
\text { (2013); } \\
\text { Bacigalupe e } \\
\text { Velasco-Martin } \\
\text { (2018). }\end{array}$ & $\begin{array}{l}\text { Tipo de aplicação utilizada pela ferramenta } \\
\text { Web, desktop, mobile }\end{array}$ \\
\hline Desenvolvedores & $\begin{array}{l}\text { Bacigalupe e } \\
\text { Velasco-Martin } \\
\text { (2018). }\end{array}$ & $\begin{array}{l}\text { Definição das entidades responsáveis pela } \\
\text { ferramenta } \\
\text { Iniciativa privada, pública, acadêmica, ONG }\end{array}$ \\
\hline $\begin{array}{l}\text { Participação } \\
\text { popular }\end{array}$ & $\begin{array}{c}\text { Bacigalupe e } \\
\text { Velasco-Martin } \\
\text { (2018) }\end{array}$ & $\begin{array}{l}\text { Identificação da existência de algum tipo de input } \\
\text { de cidadãos ou voluntários que não seja parte das } \\
\text { instituições de gerenciamento de emergência }\end{array}$ \\
\hline $\begin{array}{c}\text { Doações } \\
\text { financeiras }\end{array}$ & Autores (2019) & $\begin{array}{l}\text { Identificação de canal para recebimento ou } \\
\text { facilitação de doações do tipo financeira }\end{array}$ \\
\hline $\begin{array}{l}\text { Execução de } \\
\text { compras }\end{array}$ & Autores (2019) & $\begin{array}{l}\text { Capaz de expedir ordens de compra, bem como } \\
\text { gerenciar pedidos, fornecedores, prazos de } \\
\text { entrega e nível de serviço }\end{array}$ \\
\hline
\end{tabular}




\section{Apêndice 4 - Matriz GUT e ocorrências críticas}

\section{Quadro 17 - Matriz GUT e ocorrências do teste de usabilidade}

\begin{tabular}{|c|c|c|c|c|c|c|c|c|c|c|c|}
\hline \multicolumn{3}{|r|}{ Ocorrências } & \multicolumn{5}{|c|}{ Participantes } & \multicolumn{4}{|c|}{ Matriz GUT } \\
\hline Ranking & Tarefa & Resumo & A & B & C & D & E & Gravidade & Urgência & Tendência & $\begin{array}{l}\text { Pontuação } \\
\text { (GUT) }\end{array}$ \\
\hline $11^{\circ}$ & 2 & Não aceitou fração & & $\mathrm{x}$ & & $\mathrm{x}$ & & 4 & 4 & 4 & 64 \\
\hline $2^{0}$ & 2 & Informações inconsistentes / Insuficientes nas caixas de seleção & $\mathrm{x}$ & $x$ & $\mathrm{x}$ & $\mathrm{x}$ & $\mathrm{x}$ & 4 & 4 & 4 & 64 \\
\hline $3^{\circ}$ & 3 & $\begin{array}{l}\text { Termo "Número de dias que atende" mal compreendido. Há confusão } \\
\text { entre o número de dias que o produto atende e o número de dias que } \\
\text { a população será atendida }\end{array}$ & & & $\mathrm{x}$ & $\mathrm{x}$ & & 3 & 4 & 4 & 48 \\
\hline $4^{\circ}$ & 2 & O usuário não compreendeu o campo a ser preenchido Medida & $\mathrm{x}$ & $\mathrm{x}$ & & $\mathrm{x}$ & $\mathrm{x}$ & 3 & 3 & 4 & 36 \\
\hline $5^{0}$ & 6 & $\begin{array}{c}\text { Pelo fluxo de preenchimento não ser contínuo, o usuário tentou seguir } \\
\text { outro caminho que o leva a fazer o cadastro de uma nova cotação } \\
\text { manualmente, porém o evento cadastrado não apareceu, } \\
\text { impossibilitando a solicitação }\end{array}$ & & & $\mathrm{x}$ & $\mathrm{x}$ & $\mathrm{x}$ & 3 & 3 & 4 & 36 \\
\hline $6^{\circ}$ & 6 & $\begin{array}{c}\text { Aparecimento da mensagem "Cotação solicitada com sucesso" sem a } \\
\text { seleção prévia dos produtos }\end{array}$ & & & $x$ & & $x$ & 3 & 3 & 4 & 36 \\
\hline $7^{0}$ & 4 & $\begin{array}{l}\text { Dificuldade em achar onde são inseridas as informações para } \\
\text { identificar as necessidades do evento. Reclamação sobre o fluxo de } \\
\text { preenchimento não ser contínuo }\end{array}$ & $x$ & $x$ & $x$ & $x$ & & 3 & 3 & 3 & 27 \\
\hline
\end{tabular}

(continua) 


\section{Quadro 17 - Final}

\begin{tabular}{|c|c|c|c|c|c|c|c|c|c|c|c|}
\hline $8^{\circ}$ & 3 & Dificuldade para encontrar o botão para atualizar os índices de consumo & $\mathrm{x}$ & $\mathrm{x}$ & & $\mathrm{x}$ & $\mathrm{x}$ & 3 & 2 & 3 & 18 \\
\hline $9^{0}$ & 5 & O botão de solicitar cotação estava habilitado mesmo sem ter produtos no campo de "Operações de Compra" & $x$ & & & & $x$ & 3 & 2 & 3 & 18 \\
\hline $10^{\circ}$ & 7 & $\begin{array}{c}\text { Dificuldade de diferenciação dos campos onde deveriam ser inseridas quantidades de forma manual ou calculadas pelo } \\
\text { sistema automaticamente }\end{array}$ & & & $\mathrm{x}$ & $\mathrm{x}$ & $\mathrm{x}$ & 3 & 2 & 2 & 12 \\
\hline $11^{\circ}$ & 7 & $\begin{array}{l}\text { Posicionamento do botão "Atualizar Necessidades" fora do local logicamente esperado pelo usuário (O botão fica na parte } \\
\text { inferior do espaço para a inserção da quantidade de pessoas afetadas) }\end{array}$ & & & $\mathrm{x}$ & $\mathrm{x}$ & $\mathrm{x}$ & 3 & 2 & 2 & 12 \\
\hline $12^{\circ}$ & 6 & Dificuldade em encontrar o botão de "Solicitar cotações". Reclamação sobre o fluxo de preenchimento não ser contínuo & & $\mathrm{x}$ & & $\mathrm{x}$ & $\mathrm{x}$ & 3 & 2 & 2 & 12 \\
\hline $13^{0}$ & 6 & Falta de compreensão da diferença entre os diferentes "Estados da Operação" & & $x$ & $x$ & $x$ & & 2 & 2 & 2 & 8 \\
\hline $14^{\circ}$ & 6 & $\begin{array}{c}\text { Incômodo pelo deslocamento para o topo da página sempre que alguma ação é realizada. Para o usuário isso faz perder o } \\
\text { fluxo das etapas }\end{array}$ & $\mathrm{x}$ & & & & & 2 & 2 & 1 & 4 \\
\hline $15^{0}$ & 7 & Confusão entre as diferenças de "Situação da Pessoa" & & $x$ & & & & 2 & 1 & 1 & 2 \\
\hline $16^{0}$ & 5 & Duplo clique para acessar os eventos deveria estar habilitado. É quase instantâneo os usuários fazerem essa associação & $x$ & $x$ & & $x$ & $x$ & 2 & 1 & 1 & 2 \\
\hline
\end{tabular}




\section{Apêndice 5 - Fatores que influenciam a doação}

O instrumento 5E é utilizado para avaliar as motivações da doação, que são tópicos importantes na abordagem para manutenção de doações, assim como atração de novas. O instrumento foi respondido por 52 pessoas. A Tabela 6 apresenta o valor que os respondentes estariam dispostos a doar e sua frequência ao ano, dando uma ideia de valores melhor aceitos para doações pontuais, e com maior frequência ao ano. Importante ressaltar que todas as opções indicam que a maior frequência selecionada em todas as opções é a de 1 a 3 vezes ao ano em todos os valores, exceto de 15 a 30 reais, que pode ser um indicativo de que essa faixa possui maior possibilidade de ser doada mensalmente ao longo de um período maior. A quantia típica (mediana) doada pelo brasileiro, segundo a pesquisa realizada pelo IDIS (2015) era de $R \$ 240$ reais, enquanto a realizada em 2017 apontou uma quantia de $\mathrm{R} \$ 250$ reais. Já o valor encontrado no atual estudo é de $R \$ 247,5$ reais.

Tabela 6 - Valores preferenciais de doações ao ano (\%)

\begin{tabular}{|c|c|c|c|c|}
\hline & $\begin{array}{c}1 \text { a } 3 \text { vezes } \\
\text { a.a. }\end{array}$ & $\begin{array}{c}4 \text { a } 6 \text { vezes } \\
\text { a.a. }\end{array}$ & $\begin{array}{c}7 \text { a } 9 \text { vezes } \\
\text { a.a. }\end{array}$ & $\begin{array}{c}10 \text { a } 12 \text { vezes } \\
\text { a.a. }\end{array}$ \\
\hline até $\mathrm{R} \$ 15,00$ & 25 & 5,77 & 5,77 & 11,54 \\
\hline entre $R \$ 15,00$ e $R \$ 30,00$ & 5,77 & 13,46 & 3,85 & 13,46 \\
\hline entre $R \$ 30,00$ e $R \$ 50,00$ & 17,31 & 3,85 & 1,92 & 3,85 \\
\hline entre $R \$ 50,00$ e $R \$ 75,00$ & 7,69 & 3,85 & 1,92 & 1,92 \\
\hline entre $R \$ 75,00$ e $R \$ 100,00$ & 11,54 & - & - & 1,92 \\
\hline $\begin{array}{l}\text { entre } R \$ 100,00 \quad \text { e } \\
R \$ 200,00\end{array}$ & 15,38 & 3,85 & - & 1,92 \\
\hline acima de $\mathrm{R} \$ 200,00$ & 9,62 & - & - & 1,92 \\
\hline
\end{tabular}

Como é possível observar na Tabela 7, a "Preocupação social" é o fator com maior nível de importância. Cerca de $98 \%$ dos respondentes declaram que este fator é "Importante" ou "Muito importante", corroborando com o resultado de da Costa, Daré e Veloso (2004) e da Pesquisa Doação Brasil (IDIS, 2015), que 
apontou a "Solidariedade" como principal motivação. Já pesquisa realizada em 2017 pelo mesmo instituto (IDIS,2017) aponta o fator "Sentir-se bem" como a principal motivação, migrando de um perfil mais altruísta e preocupado com questões coletivas para um perfil mais personalístico. Nos resultados do presente estudo observa-se o fator correspondente "Satisfação interna gerada" é considerado "Importante" ou "Muito importante" por cerca de 60\% dos respondentes, contudo a "Identificação com a organização" possui um peso aparentemente maior para os respondentes, o que demonstra que além de buscar doadores alinhados com sua missão, é importante divulgar continuamente o trabalho e ações realizadas, além de que aspectos cognitivos podem ser considerados na captação de recursos. Já o fator "Imagem pessoal" é uma questão pouco relevante, assim como na pesquisa de da Costa, Daré e Veloso (2004) e nas realizadas pelo IDIS $(2015,2017)$.

Tabela 7 - Fatores motivacionais no ato de doar

\begin{tabular}{cccccc|cc}
\hline & $\begin{array}{c}\text { Nada } \\
\text { importante }\end{array}$ & $\begin{array}{c}\text { Pouco } \\
\text { importante }\end{array}$ & Indiferente & Importante & $\begin{array}{c}\text { Muito } \\
\text { importante }\end{array}$ & & \\
\hline & $\%$ & $\%$ & $\%$ & $\%$ & $\%$ & $\underline{\underline{ \pm}}$ \\
\hline $\begin{array}{c}\text { Preocupação } \\
\text { social }\end{array}$ & - & - & 1,96 & 31,37 & 66,67 & 4,65 & 0,52 \\
\hline $\begin{array}{c}\text { Identificação } \\
\text { com a } \\
\text { organização }\end{array}$ & 5,88 & 5,88 & 19,61 & 49,02 & 19,61 & 3,71 & 1,04 \\
\hline $\begin{array}{c}\text { Satisfação } \\
\text { interna gerada }\end{array}$ & 3,92 & 9,8 & 25,49 & 41,18 & 19,61 & 3,63 & 1,04 \\
\hline $\begin{array}{l}\text { Imagem } \\
\text { pessoal }\end{array}$ & 37,25 & 17,65 & 37,25 & 5,88 & 1,96 & 2,18 & 1,07 \\
\hline $\begin{array}{c}\text { Minha religião } \\
\text { prega a } \\
\text { caridade }\end{array}$ & 31,37 & 11,76 & 33,33 & 17,65 & 5,88 & 2,55 & 1,27 \\
\hline
\end{tabular}

Sobre o grau de importância de informações ao avaliar a confiabilidade da instituição, quase todas as opções foram consideradas importantes ou muito importantes mais de $80 \%$ dos respondentes, exceto pela orientação religiosa da instituição. Ao agruparmos as escalas "Importante" e "Muito importante" temos a seguinte ordem de importância: transparência; existirem controles adequados das atividades; técnicas de captação apropriadas e não invasivas; área e foco de atuação; responsáveis pela instituição; histórico da entidade e orientação religiosa. Essa ordem de importância é a mesma da pesquisa de da Costa, Daré e Veloso (2004), exceto pela troca de posição entre área de atuação e gestores, 
enfatizando sua importância. Os percentuais relacionados a cada um dos fatores são mostrados no Quadro 18.

Quadro 18 - Importância de fatores para o doador

\begin{tabular}{|c|c|c|c|c|c|}
\hline & $\begin{array}{c}\text { Nada } \\
\text { importante }\end{array}$ & $\begin{array}{l}\text { Pouco } \\
\text { importante }\end{array}$ & Indiferente & Importante & $\begin{array}{c}\text { Muito } \\
\text { importante }\end{array}$ \\
\hline $\begin{array}{l}\text { Histórico da entidade (prêmios } \\
\text { recebidos, } \\
\text { realizadas, campanha } \\
\text { público, etc.) }\end{array}$ & $4 \%$ & $4 \%$ & $12 \%$ & $36 \%$ & $44 \%$ \\
\hline Área e foco de atuação & $2 \%$ & $2 \%$ & $4 \%$ & $52 \%$ & $40 \%$ \\
\hline $\begin{array}{l}\text { Quem são os responsáveis e } \\
\text { gestores da instituição. }\end{array}$ & $2 \%$ & $8 \%$ & $2 \%$ & $52 \%$ & $36 \%$ \\
\hline $\begin{array}{l}\text { Orientação } \quad \text { religiosa } \quad \text { da } \\
\text { instituição. }\end{array}$ & $36 \%$ & $12 \%$ & $40 \%$ & $10 \%$ & $2 \%$ \\
\hline $\begin{array}{l}\text { A instituição se pautar pela } \\
\text { transparência das suas ações e } \\
\text { objetivos. }\end{array}$ & $2 \%$ & $0 \%$ & $0 \%$ & $32 \%$ & $66 \%$ \\
\hline $\begin{array}{l}\text { A instituição utilizar técnicas de } \\
\text { captação de recursos que são } \\
\text { apropriadas e não invasivas. }\end{array}$ & $0 \%$ & $0 \%$ & $4 \%$ & $46 \%$ & $50 \%$ \\
\hline $\begin{array}{l}\text { Existirem controles adequados } \\
\text { das atividades da organização }\end{array}$ & $0 \%$ & $0 \%$ & $4 \%$ & $42 \%$ & $54 \%$ \\
\hline
\end{tabular}

Uma informação que pode ser útil às instituições refere-se aos resultados sobre quais ferramentas de mídia são consideradas determinantes para os respondentes seja na busca por informações ou na divulgação de solicitação de doações. As ferramentas considerada mais influente são as redes sociais, o que pode ser um indício de que as mídias digitais exerçam um papel importante no processo decisório, contudo há a observação de que a média de idade dos respondentes é de 27 anos, que pode inflar esse ponto especificamente, já que os jovens utilizam muito esse tipo de ferramenta. É seguida pela TV, que ainda é um veículo com grande penetração nos lares brasileiros e que traz grande visibilidade para as campanhas, que pode ser aliada a outra opção considerada importante: as campanhas publicitárias das próprias instituições. Abordagens mais tradicionais como abordagem pessoal, e-mail, SMS e ligação telefônica são pouco selecionadas e mostram a necessidade de adaptação das instituições.

O Quadro 19 aponta as formas de pagamento preferenciais. Essa pergunta é do tipo seleção múltipla, sendo possível selecionar mais de uma opção e foi respondida por 52 pessoas. Os resultados evidenciam que não há uma superioridade preferencial em nenhuma das formas de pagamento, contudo demonstram uma predileção por meios de pagamento mais práticos e sem a 
necessidade de deslocamento para sua efetivação, como é o caso do uso de cartões de crédito e débito. Este resultado contraria o resultado da Country Giving Report (IDIS, 2017), na qual a maioria dos respondentes (cerca de 37\%) afirma doar de maneira recorrente em dinheiro entregue na própria instituição. Essa informação é interessante visto que talvez a forma preferencial de doação não esteja disponível em todos os tipos de instituições e ajuda. Contudo pode ser uma oportunidade de busca por soluções que possam oferecer flexibilidade para o doador por parte das instituições.

\section{Quadro 19 - Formas de pagamento preferenciais}

\begin{tabular}{|l|c|}
\hline \multicolumn{1}{|c|}{ Formas de pagamento } & $\%$ \\
\hline Boleto & $58 \%$ \\
\hline Cartão de crédito & $52 \%$ \\
\hline Débito em conta corrente & $48 \%$ \\
\hline Depósito bancário & $38 \%$ \\
\hline Em dinheiro na própria instituição & $17 \%$ \\
\hline Ligação telefônica (0800) & $0 \%$ \\
\hline
\end{tabular}

O Quadro 20 traz as formas preferenciais de acompanhamento de resultado das instituições pelos respondentes, e as mídias sociais novamente despontam como a forma preferida, mas não única. O envio de informativos por e-mail e atualização das ações no próprio site da instituição também são considerados por grande parte dos respondentes. Já as mídias mais tradicionais como TV e rádio não são considerados por muitos potenciais doadores como forma efetiva de acompanhamento.

Quadro 20 - Formas preferenciais para acompanhamento

\begin{tabular}{|l|c|}
\hline Forma de acompanhar o que é realizado a partir das doações & $\%$ \\
\hline Através de publicações em mídias sociais & $75 \%$ \\
\hline Através de e-mails informativos com um balanço sobre a campanha & $65 \%$ \\
\hline No próprio site da instituição. & $60 \%$ \\
\hline Através de reportagens na mídia (rádio, televisão, sites, etc.) & $35 \%$ \\
\hline
\end{tabular}

Já que é uma prerrogativa do sistema a possibilidade de auditar as operações entender a receptividade desse aspecto é importante. Fica evidente a predileção por uma auditoria externa, considerada confiável por $98 \%$ dos respondentes, porém esse processo pode ser caro do ponto de vista financeiro e logístico, portanto é importante avaliar se os $67 \%$ que considerou a auditoria interna confiável não compensariam a possível perda de doações em decorrência dessa escolha. 
Em relação ao feedback desejado $69 \%$ afirmam que apenas um e-mail de agradecimento é suficiente, enquanto $21 \%$ preferem o certificado de doação. Outras sugestões surgiram e basicamente todos os demais respondentes esperam a ampla divulgação dos resultados da campanha, não só com divulgação de valores arrecadados, mas principalmente com o que de fato está sendo realizado.

Por fim, quando questionados sobre a possibilidade de indicação do sistema para outras pessoas $72 \%$ afirmam que o fariam, enquanto $29 \%$ afirma que talvez faria, o que é um bom indício para o sistema. 


\section{Anexo 1 - Instrumento de pesquisa 4 - SUMI}

\begin{tabular}{|c|c|c|c|}
\hline & Concordo & Não Sei & Discordo \\
\hline Este software responde muito lentamente aos comandos. & & & \\
\hline Eu recomendaria este software aos meus colegas. & & & \\
\hline As instruções e comandos são úteis. & & & \\
\hline Este software parou em algum momento inesperadamente. & & & \\
\hline Inicialmente aprender a operar este software é muito problemático. & & & \\
\hline Eu às vezes não sei o que fazer a seguir com este software. & & & \\
\hline Eu aprecio o tempo que gasto usando este software. & & & \\
\hline Acho que a informação de ajuda fornecida por este software não é muito útil. & & & \\
\hline Se este software parar, não é fácil reiniciá-lo. & & & \\
\hline As funções do software levam muito tempo para serem aprendidas. & & & \\
\hline Às vezes me pergunto se estou usando a função certa. & & & \\
\hline Trabalhar com este software é satisfatório. & & & \\
\hline A forma como as informações do sistema são apresentadas é clara e compreensível. & & & \\
\hline Eu me sinto mais seguro quando uso apenas algumas funções familiares. & & & \\
\hline A documentação do software é muito informativa. & & & \\
\hline
\end{tabular}




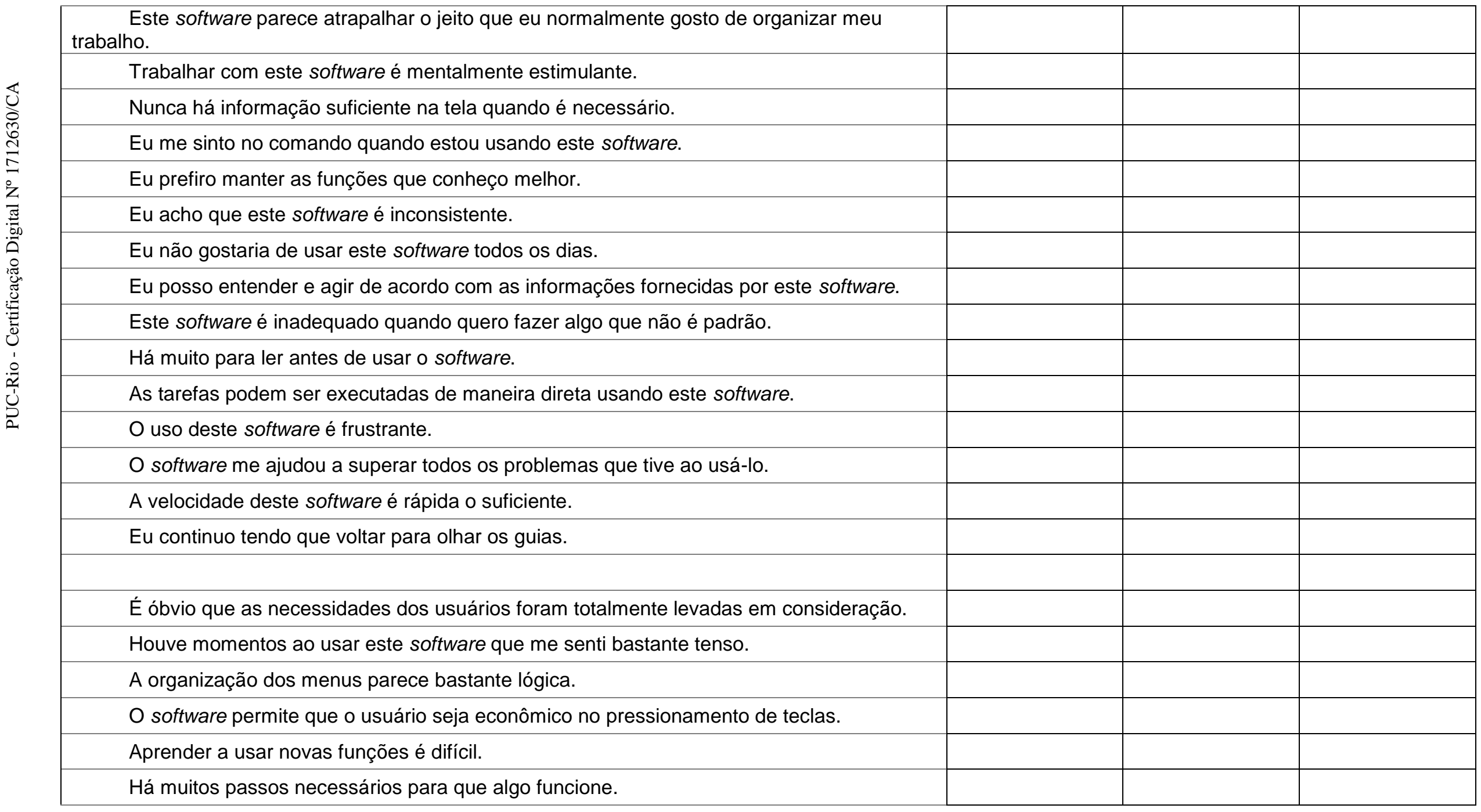




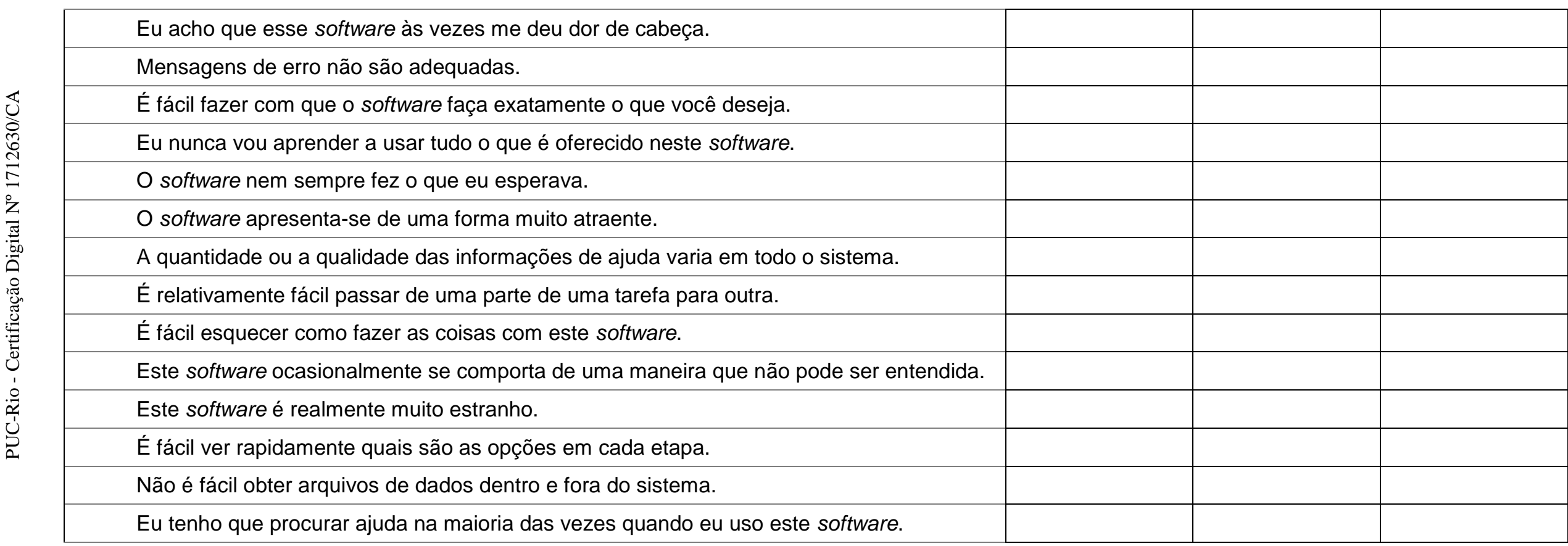

Quão importante para você é o tipo de software que você acabou de classificar?

( ) Extremamente importante ( ) Importante ( ) Não muito importante ( ) Nada importante

Qual é o melhor aspecto deste software e por quê?

O que você acha que precisa melhorar mais e por quê? 